\title{
Inventory and Description of Commercial Reactor Fuels within the United States
}

Fuel Cycle Research \& Development

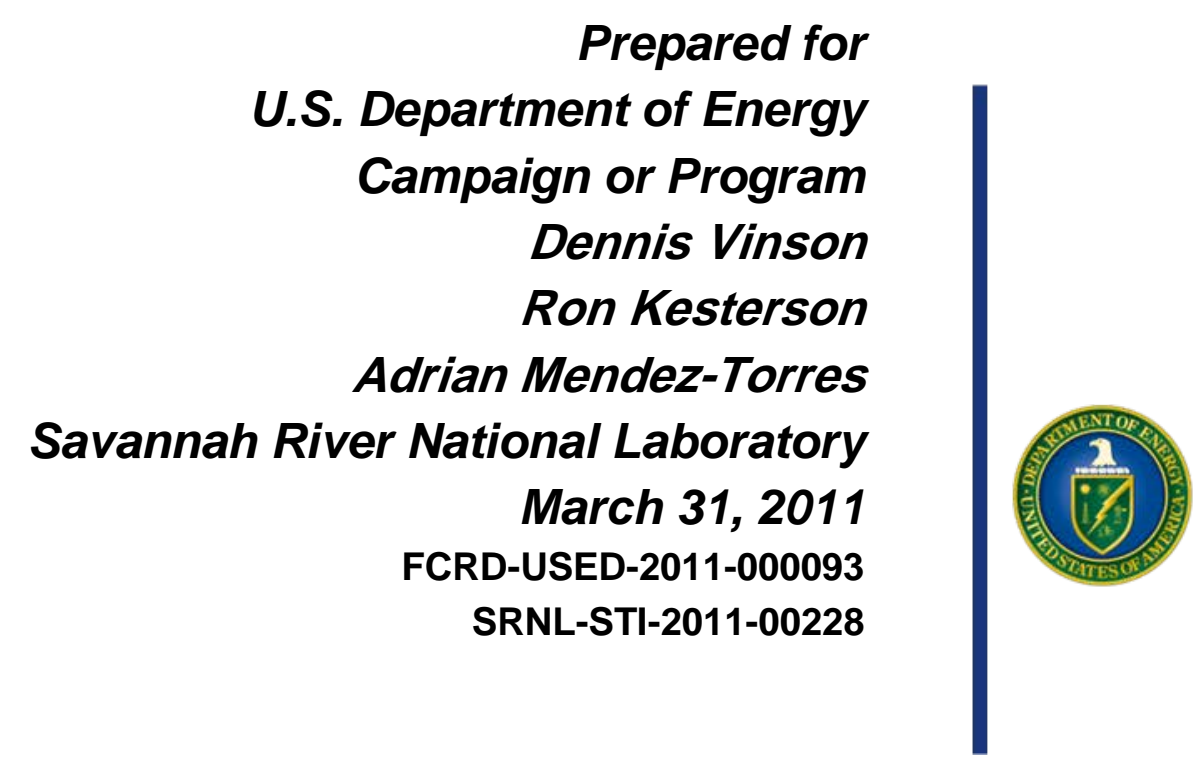




\section{DISCLAIMER}

This information was prepared as an account of work sponsored by an agency of the U.S. Government. Neither the U.S. Government nor any agency thereof, nor any of their employees, makes any warranty, expressed or implied, or assumes any legal liability or responsibility for the accuracy, completeness, or usefulness, of any information, apparatus, product, or process disclosed, or represents that its use would not infringe privately owned rights. References herein to any specific commercial product, process, or service by trade name, trade mark, manufacturer, or otherwise, does not necessarily constitute or imply its endorsement, recommendation, or favoring by the U.S. Government or any agency thereof. The views and opinions of authors expressed herein do not necessarily state or reflect those of the U.S. Government or any agency thereof. 


\section{SUMMARY}

There are currently 104 nuclear reactors in 31 states, operated by 51 different utilities. Operation of these reactors generates used fuel assemblies that require storage prior to final disposition. The regulatory framework within the United States (U.S.) allows for the licensing of used nuclear fuel storage facilities for an initial licensing period of up to 40 years with potential for license extensions in 40 years increments. Extended storage, for periods of up to 300 years, is being considered within the U.S. Therefore, there is an emerging need to develop the technical bases to support the licensing for long-term storage. In support of the Research and Development (R\&D) activities required to support the technical bases, a comprehensive assessment of the current inventory of used nuclear fuel based upon publicly available resources has been completed that includes the most current projections of used fuel discharges from operating reactors.

Negotiations with the nuclear power industry are ongoing concerning the willingness of individual utilities to provide information and material needed to complete the R\&D activities required to develop the technical bases for used fuel storage for up to 300 years. This report includes a status of negotiations between DOE and industry in these regards. These negotiations are expected to result in a framework for cooperation between the Department and industry in which industry will provide and specific information on used fuel inventory and the Department will compensate industry for the material required for Research and Development and Testing and Evaluation Facility activities. 


\section{This Page Intentionally Left Blank}




\section{CONTENTS}

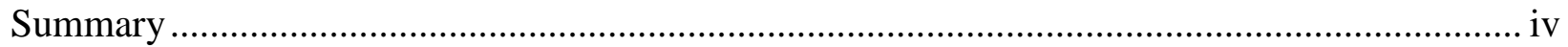

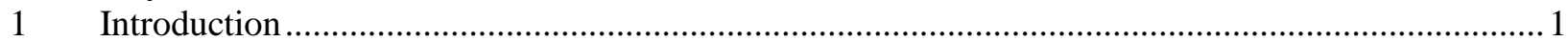

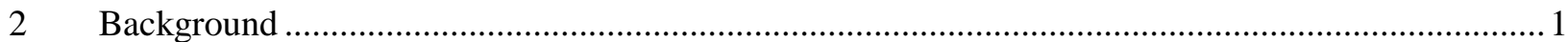

3 Description of U.S. Commercial Reactors and Reactor Fuels ...................................................... 2

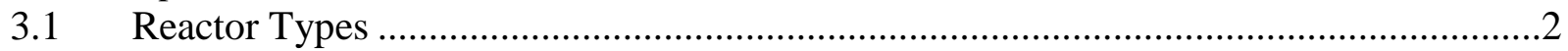

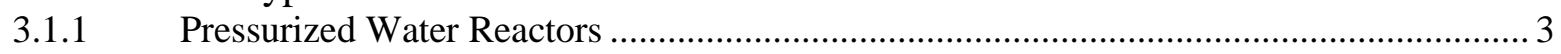

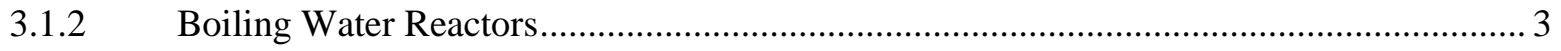

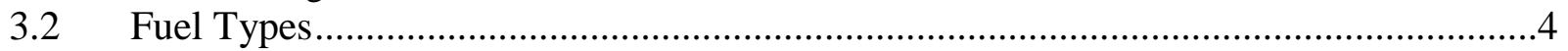

3.2.1 Pressurized Water Reactor Fuel.................................................................................. 4

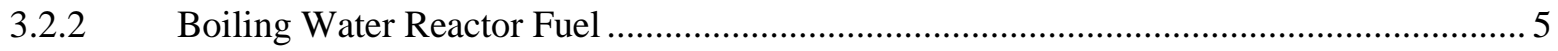

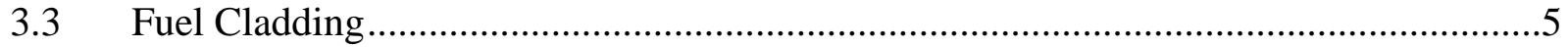

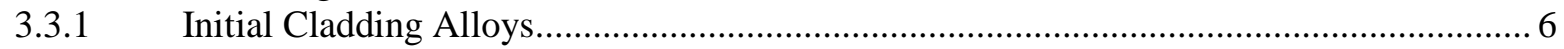

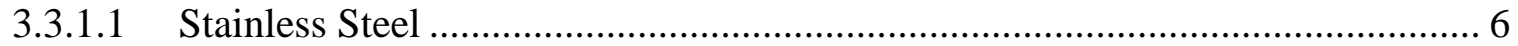

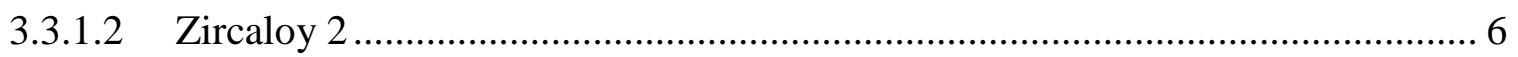

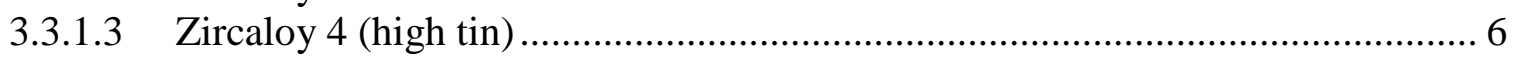

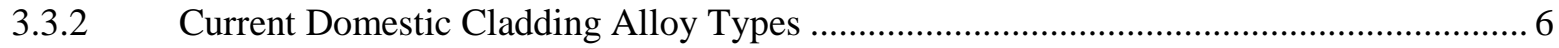

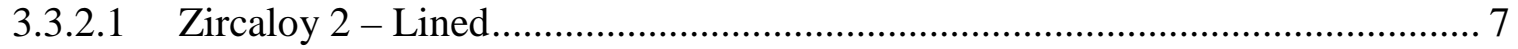

3.3.2.2 Low Tin - Improved Zircaloy 4 ........................................................... 7

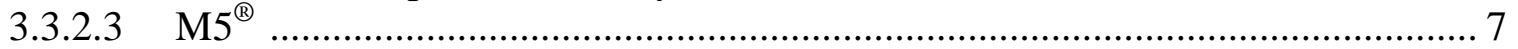

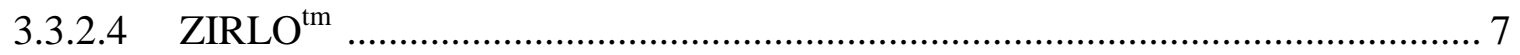

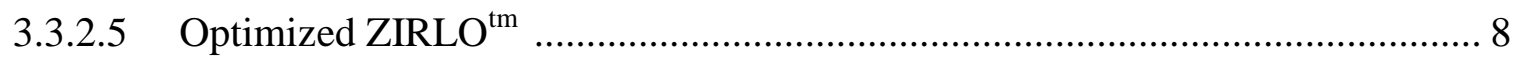

3.3.2.6 Potential New Advanced Metal Alloy Cladding ......................................... 8

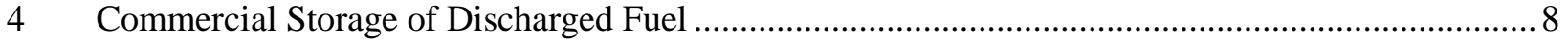

4.1 Commercial Wet Storage in Fuel Pools....................................................................9

4.2 Commercial Dry Storage of Discharged Fuel.......................................................11

4.3 Used Nuclear Fuel Storage at Shutdown Reactors ....................................................12

$5 \quad$ Federal Storage of Discharged Commercial Fuel ...................................................................... 13

$6 \quad$ Potential Collaboration between the Department and Industry................................................... 13

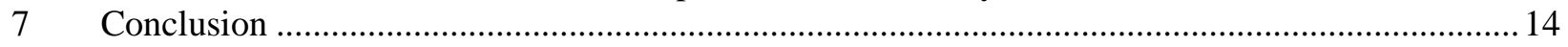

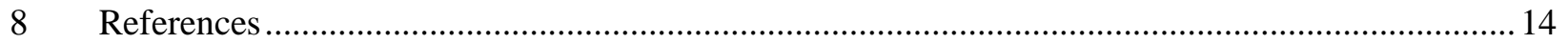




\section{FIGURES}

Figure 1

Figure 2

Figure 3

Figure 4

Figure 5

Figure 6

Figure 7

Figure 8

Figure 9
Schematic of a Pressurized Water Reactor (PWR).

Schematic of a Boiling Water Reactor (BWR).

U.S. Nuclear Fuel Assembly.

Reactor Storage Pools, Independent Spent Fuel Storage Installations, Federal, and Other

Sites.

Used Fuel Pool at Yankee Rowe.

Cumulative Number of Filled Fuel Pools

U.S. Independent Spent Fuel Storage Installations.

Connecticut Yankee Dual-Purpose Dry Storage Facility.

Used Fuel Dry Storage Systems

\section{TABLES}

Table 1

Table 2

Table 3

Table 4

Table 5

Table 6

Table 7

Table 8

Table 9

Table 10

Table 11

Table 12

Table 13

Table 14

Table 15

Table 16

Table 17

Table 18

Table 19

Table 20

Table 21

Table 22
Commercial Power Reactors in the U.S. 18

Total Number of U.S. Reactors by Utility 22

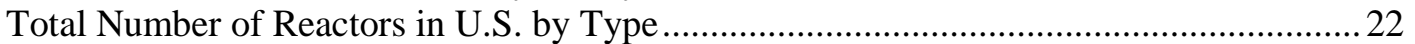

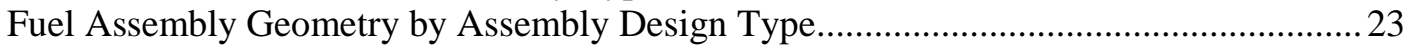

Nominal Compositions of Alloys Used as Nuclear Fuel Cladding ................................... 23

Reactor Storage Pools, Independent Spent Fuel Storage Installations, Federal, and Other Sites ${ }^{15}$

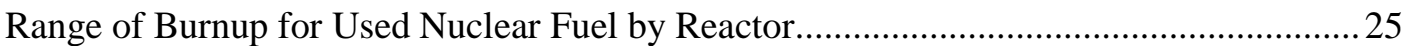

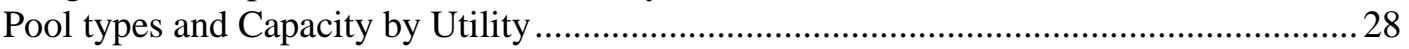

Status of Used Fuel Storage at Commercial Nuclear Power Plants. (NEI) .......................... 32

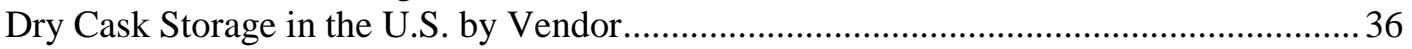

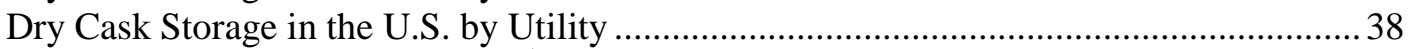

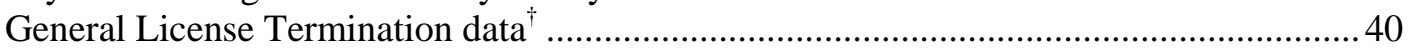

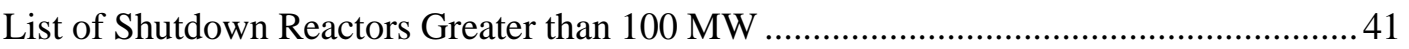

Decommissioning Status for Shutdown Power Reactors ................................................ 42

Cumulative Commercial Reactor Discharges................................................................. 43

Commercial Inventory of Uranium Oxide Fuel being Stored Dry at Argonne National

Laboratory - East .......................................................................................................... 46

Commercial Inventory of Uranium Oxide Fuel being Stored Dry at Hanford

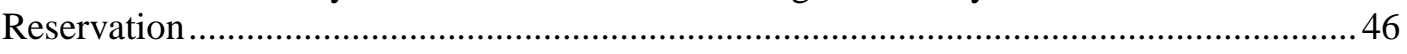

Commercial Inventory of Uranium Oxide Fuel being Stored Dry at Idaho National

Laboratory

Commercial Inventory of Uranium Oxide Fuel being Stored Wet at the Savannah River

Site

Commercial Fuel Inventory of Uranium Oxide Fuel being Stored Dry at B\&W

Lynchburg Technology Center.

Supplemental Information on Commercial Fuel Inventory at B\&W Lynchburg

Technology Center

University Research Reactors Reporting Spent Fuel (CRS) 
ACRONYMS

$\begin{array}{ll}\text { AFR } & \text { Away-From-Reactor } \\ \text { BWR } & \text { Boiling Water Reactor } \\ \text { EBWR } & \text { Experimental Boiling Water Reactor } \\ \text { DOE } & \text { U.S. Department of Energy } \\ \text { FBR } & \text { Fast Breeder Reactor } \\ \text { ID } & \text { Inner Diameter } \\ \text { ISFSI } & \text { Independent Spent Fuel Storage Facility } \\ \text { HTGR } & \text { High-Temperature Gas-Cooled and Moderated Reactor } \\ \text { NRC } & \text { U.S. Nuclear Regulatory Commission } \\ \text { OMR } & \text { Organic-Cooled and Moderated Reactor } \\ \text { PCI } & \text { Pellet Clad Interaction } \\ \text { PHWR } & \text { Pressurized Heavy Water Reactor } \\ \text { PWR } & \text { Pressurized Water Reactor } \\ \text { R\&D } & \text { Research and Development } \\ \text { TEF } & \text { Testing and Evaluation Facility } \\ \text { UFD } & \text { Used Fuel Disposition } \\ \text { U.S. } & \text { United States of America } \\ \text { U.K. } & \text { United Kingdom }\end{array}$


This Page Intentionally Left Blank 


\section{UFD/R\&D OPPORTUNITIES INVENTORY AND DESCRIPTION OF COMMERCIAL REACTOR FUELS WITHIN THE UNITED STATES}

\section{INTRODUCTION}

In the United States, nuclear energy provides approximately 20 percent of the total energy production. This makes nuclear power plants the number one source of emission-free electricity in the U.S. There are currently 104 nuclear reactors in 31 states, operated by 51 different utilities.

Operation of these reactors generates used fuel assemblies that require storage prior to final disposition. With the issuance of the policy decision to eliminate Yucca Mountain for consideration as the repository for final disposition of more than 70,000 MTIHM of used nuclear fuel, the storage times required for storage prior to disposition have been greatly increased. There remains no solution for final disposition of used nuclear fuel and no candidates have been identified. The expectation is that used nuclear fuel would remain in prolonged interim storage for up to 300-years.

The regulatory framework within the U.S. allows for the licensing of used nuclear fuel storage facilities for an initial licensing period of up to 40 years with potential for license extensions in 40 years increments. With the expectation shifting from storage for a couple of decades to storage for several millennia, there is an emerging need to develop the technical bases for such extended storage time periods. Development of these technical bases will require research and development (R\&D) activities directed at filling specific data and technology gaps that are identified in the technical bases for what has been termed "very long-term storage" $(120 \rightarrow 300$ years storage). The purpose of the current work is to develop a comprehensive inventory of used nuclear fuel within the U.S. and to identify potential opportunities for, barriers to, and conditions of collaboration between the current (the utilities) and future (U.S. Department of Energy) owners of the used fuel to conduct the necessary R\&D to fill the data gaps.

\section{BACKGROUND}

The discovery of nuclear fission in Germany was first announced 1939. Initial research in nuclear fission technologies were aimed at development of nuclear weapons. However, this research provided for the development of enrichment technologies and research into the reactor development at the University of Chicago, where the first self-sustaining chain reaction was reported in December 1942. Research at the Chicago Pile experimental reactor lead to the development of the first production reactors at Hanford, Washington and Oak Ridge, Tennessee.

The first reactor for large- scale commercial production of power was the $20 \mathrm{MW}_{\mathrm{e}}$ Calder Hall reactor, started in 1956 in U.K. The first reactor power project in the U.S. started in 1946. In 1955, the BORAX-III became the first U.S. reactor to put power into a utility on a continuous basis. The Experimental Boiling Water Reactor (EBWR) was commissioned in 1957 and is considered the first commercial-scale reactor in the U.S. From the mid sixties through the early 
seventies, the number and size of commercial power reactors rapidly increased in the U.S. This trend reversed in the late seventies as orders for new reactors ceased and current projects were cancelled as the demand failed to live up to the projected growth and cost of licensing increased. Accidents in March 1979 and in April of 1986 contributed to the cessation of orders for new nuclear power reactors.

During the forty years between 1956 and 1996, the U.S. nuclear power industry experienced the startup of 134 reactors, including a few early prototype reactors (see Table 1). Of these, there are 104 commercial reactors currently producing electric power, while the other 30 reactors have been shutdown. The existing reactor base is generating approximately $100,000 \mathrm{MW}_{\mathrm{e}}$ and supplying around $20 \%$ of the U.S. electric demand. With the production of power, reactor fuel is consumed or converted and discharged from the operating reactors at end of life and during the downtime between the 12-24 month operating cycles. The discharged, or used, reactor fuel must be managed prior to final disposition.

From the beginning of the commercial nuclear power program in the U.S., used commercial power reactor fuel was intended to be removed from the operating reactor sites for final disposition. However, indecision over the final disposition of this material has plagued the nuclear industry to date. Original expectations were that the used fuel would be reprocessed in order to sustain the nuclear industry without exhausting what was thought to be limited natural uranium deposits. Therefore, the reactors were designed with limited storage capacity in fuel pools while awaiting the reprocessing option to materialize. In the early eighties, the official U.S. policy shifted away from reprocessing and adopted a once-through fuel cycle. The Nuclear Waste Policy Act of 1982 provided a framework through which the government, through the U.S. Department of Energy (DOE), would take possession of the used fuel and arrange for a permanent disposal facility. To date, a national facility for permanent disposal of used fuel has not been realized due to technical and political challenges. Current legislation precludes DOE from taking possession of the used fuel, necessitating extended storage periods for used fuel at individual reactors and at independent spent fuel storage facilities (ISFSI).

\section{DESCRIPTION OF U.S. COMMERCIAL REACTORS AND REACTOR FUELS}

\subsection{Reactor Types}

Currently, there are 104 operating light water reactors within the United States operated by 51 utilities. Table 2 provides a list of the utilities in the U.S. with the number of reactors owned by each. Of the 104 operating reactors, 69 are pressurized water reactors (PWRs), and the remaining 35 are boiling water reactors (BWRs). Following is a description of these two reactor types. In addition to PWRs and BWRs, the U.S. has some commercial (small-scale) and experimental reactor experience with several other reactor designs including a pressurized heavy water reactor (PHWR), a few fast breeder reactors (FBRs), a couple high-temperature, gascooled reactors (HTGRs), a couple sodium-graphite (Na-graphite) reactors, and an organic cooled and moderated reactor (OMR). Table 3 provides a listing of reactors in the U.S. by type. These reactors have all been shut down, and the used fuel associated with these reactors does not contribute significantly to the U.S. used fuel inventory. As such, these reactor types are not discussed further in the current report. 


\subsubsection{Pressurized Water Reactors}

A pressurized water reactor is a light water moderated reactor and is the primary reactor type operating in the U.S. today. For PWRs, the primary coolant loop contains light water that is used to remove heat from the core that is transferred to a secondary coolant loop in a steam generator. The primary coolant loop is maintained at high pressure to prevent the boiling within the loop. The primary coolant also functions as the neutron moderator that slows the neutrons to thermal energies. Figure 1 is a representation of a typical commercial PWR.

The primary coolant transfers heat to the water of the secondary loop in large heat exchangers, called steam generators. Water within the secondary loop is held at lower pressure and allowed to boil to generate steam. The steam is then used to generate electricity through steam turbines, before being condensed and directed back to the steam generators again.

\subsubsection{Boiling Water Reactors}

The boiling water reactor is the second major type of light water reactor operating in the U.S. In these reactors, the pressure in the single coolant loop is maintained at a much lower pressure than that of a PWR. This lower pressure allows for boiling of the light water coolant/moderator to create steam to drive steam turbines. The steam is subsequently cooled in a condenser and returned as a liquid back to the core to complete the cycle. Figure 2 is a representation of a typical commercial BWR.

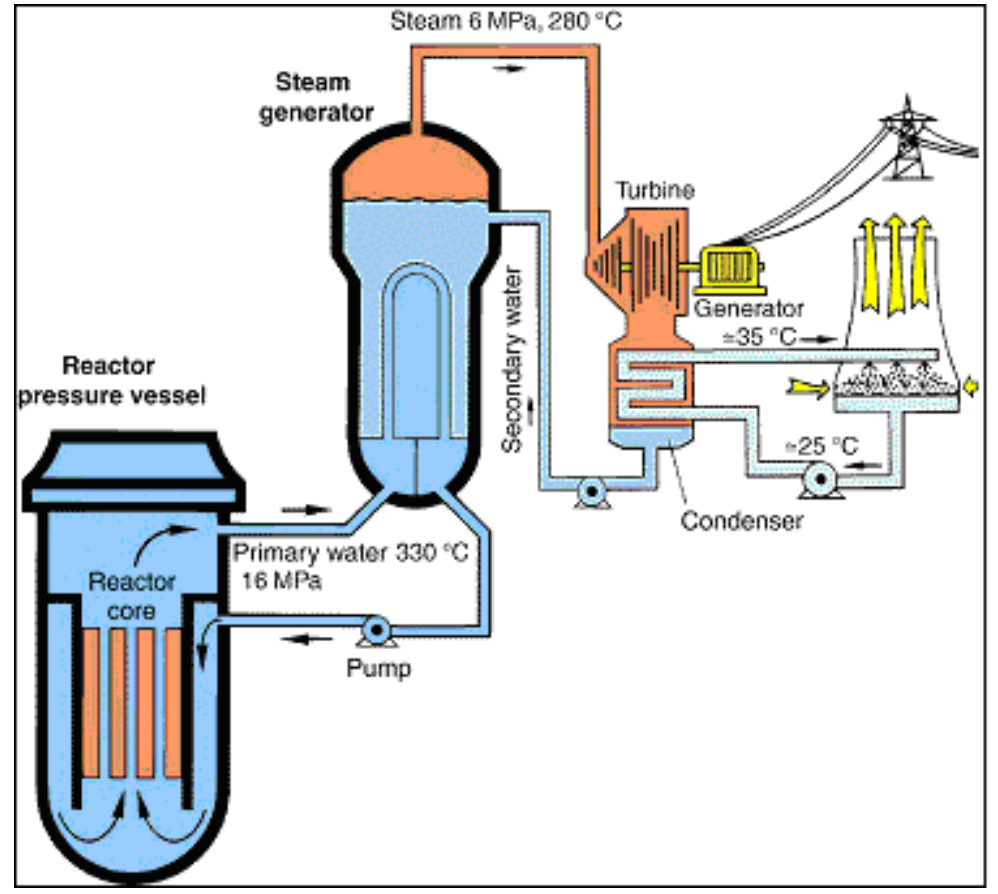

Figure 1 Schematic of a Pressurized Water Reactor (PWR). ${ }^{1}$ 


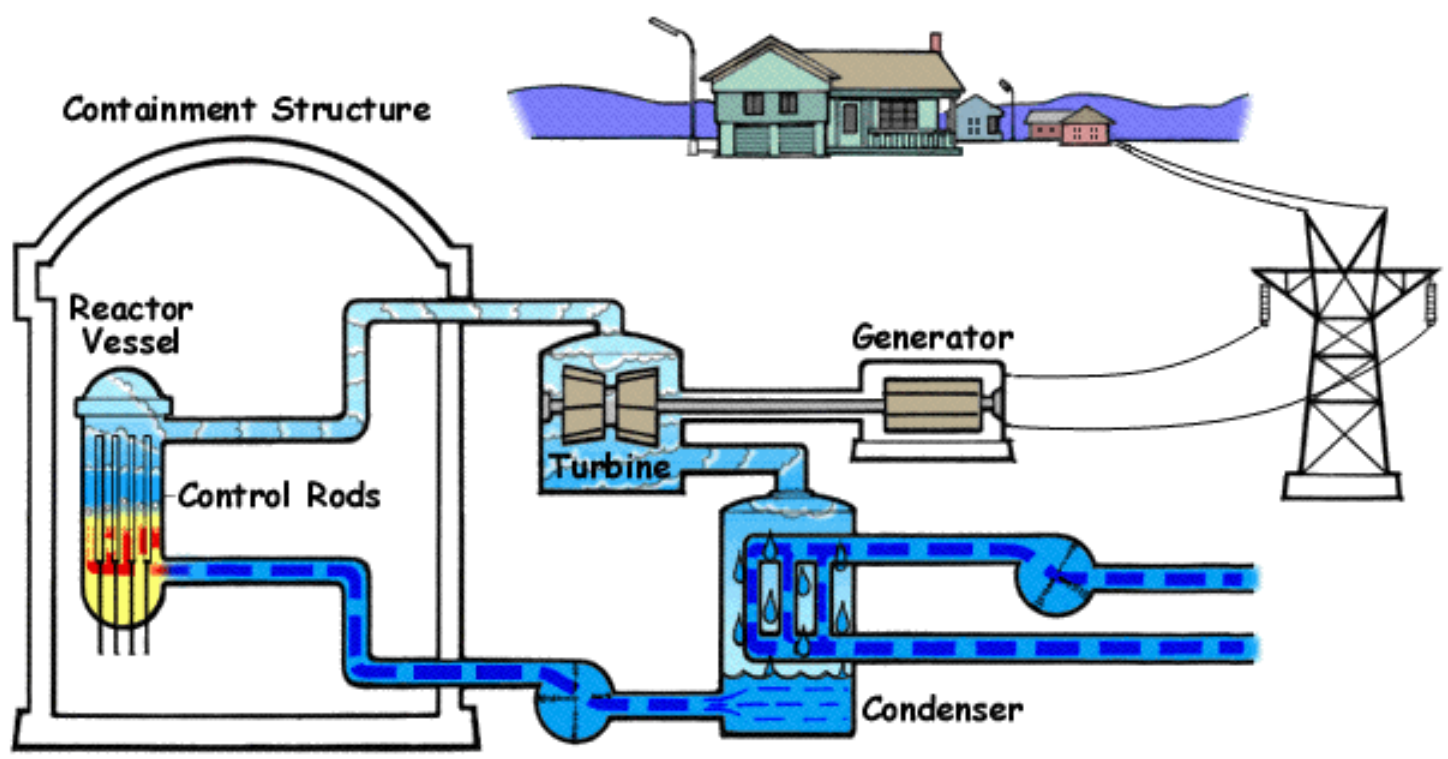

Figure 2 Schematic of a Boiling Water Reactor (BWR). ${ }^{2}$

The design of a boiling water reactor differs significantly from that of a pressurized water reactor in that the boiling water reactor has a single coolant loop that boils within the reactor vessel. The cooling water in the boiling water reactor is generally maintained at about $75 \mathrm{~atm}$ (7.6 MPa, $1000-1100$ psi) so that it boils in the core at about $285^{\circ} \mathrm{C}\left(550^{\circ} \mathrm{F}\right)$. For comparison, the PWR primary coolant is maintained at significantly higher pressure (158 atm) to preclude boiling.

\subsection{Fuel Types}

Uranium is the conventional reactor fuel in the U.S. For use as nuclear fuel in commercial reactors, the uranium in $U_{6}$ gas enriched in $U^{235}$ to a value of $3-5 \%$. The enriched $U_{6}$ is converted into uranium dioxide $\left(\mathrm{UO}_{2}\right)$ powder that is processed into pellet form and fired in a high-temperature, sintering furnace to create hard, ceramic pellets of enriched uranium. The cylindrical pellets are ground to consistent size and clad in corrosion-resistant alloy tubes of approximately 1-cm diameter. The majority of U.S. used fuel inventory is clad in an alloy of zirconium and aluminum due to the high corrosion resistance and low affinity for absorbing neutrons. The loaded tube is sealed and backfilled with helium, for improved thermal heat transfer between the fuel and the cladding and reduce pellet clad interaction and internal cladding degradation. The finished fuel rods are grouped into fuel assemblies that are used to build the core of a power reactor. Figure 3 provides images of some U.S. reactor fuel. Table 4 provides geometry data for fuel assemblies by assembly design type.

\subsubsection{Pressurized Water Reactor Fuel}

Typical pressurized water reactor fuel bundles/assemblies contain 179-264 rods each and between 125 to 250 such bundles/assemblies makes up a typical reactor core. In general, each fuel bundle is comprised of $14 \times 14$ to $17 \times 17$ array of fuel rods that are approximately 4 meters 
in length. A typical PWR reactor core would contain about 80-100 tonnes of uranium and produce 800 to $1300 \mathrm{MW}_{\mathrm{e}}{ }^{3}$

\subsubsection{Boiling Water Reactor Fuel}

Boiling water reactor fuel is similar to pressurized water reactor fuel, except that boiling water reactor fuel bundles are enclosed a channel made typically of Zircaloy 2 for neutron and thermal hydraulic purposes. In general, each BWR fuel bundle contains 60 to 100 fuel rods per bundle and between 368 to 800 bundles per reactor core.

\subsection{Fuel Cladding}

Cladding is the outer layer of the fuel rods, separating the coolant and the nuclear fuel pellets. It is made of a corrosion-resistant material with low absorption cross section for thermal neutrons. The older clad alloys are usually Zircaloy 2 or 4 and some of the newer assemblies incorporate advanced zirconium based alloys. Below is a discussion of the various fuel cladding alloys.

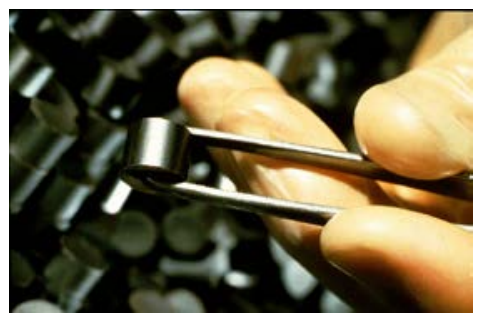

Pre-irradiated Fuel Pellets. ${ }^{4}$
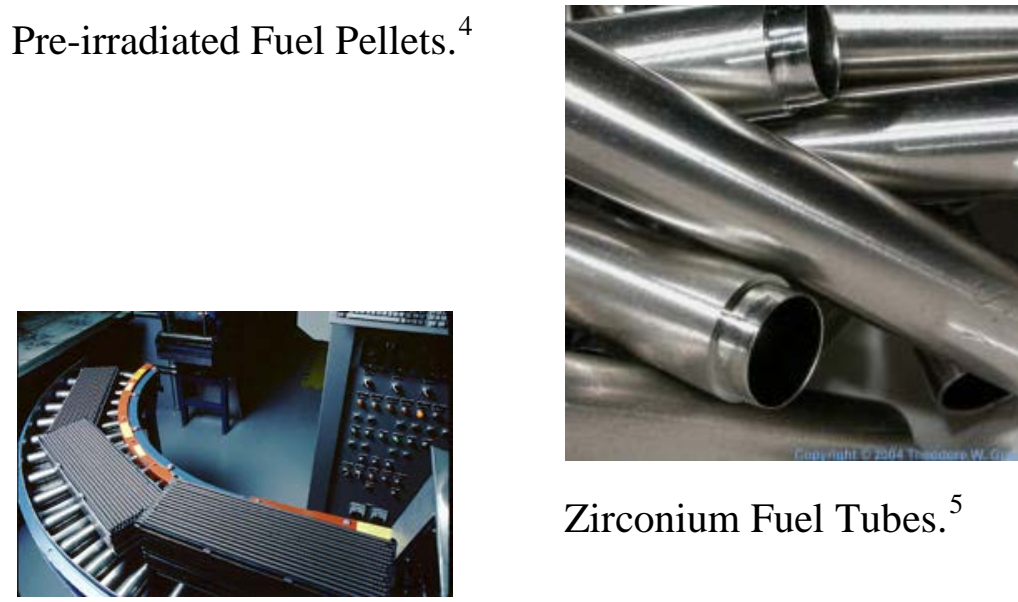

Zirconium Fuel Tubes. ${ }^{5}$

Pre-irradiated Fuel Pellets ready for assembly.

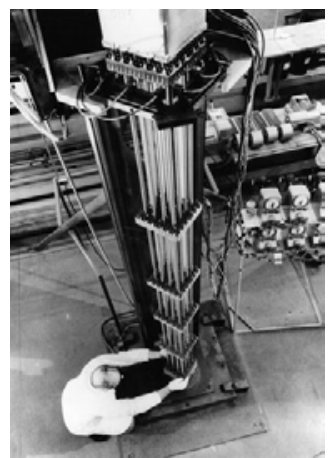

A Fuel Assembly. ${ }^{5}$

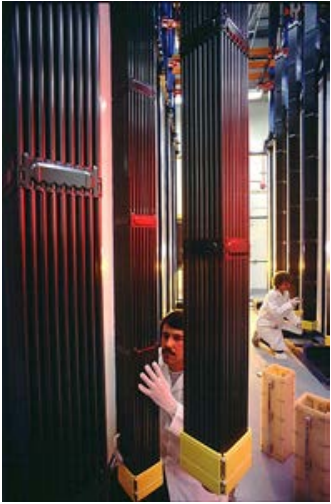

New (pre-irradiated) U.S. fuel being inspected. ${ }^{4}$

Figure 3 U.S. Nuclear Fuel Assembly. 


\subsubsection{Initial Cladding Alloys}

\subsubsection{Stainless Steel}

Until the late-1970s commercial fuel rods used austenitic stainless steel that was primarily Type 304 as cladding with some Type $348 \mathrm{H} .{ }^{6}$ Issues with stress corrosion cracking in the stainless steel cladding resulted in a shift to Zircaloy 2 for BWR applications. ${ }^{7}$ In PWR reactors the SS cladding performed well regarding fabricability and corrosion resistance during operation, but it had a relatively high thermal neutron absorption cross section. Because of this negative neutron economy impact, the stainless steel cladding was phased out and replaced by Zircaloy-4. With this early phase-out of SS cladding, there exists in storage only a small fraction of SS clad commercial spent fuel assemblies.

\subsubsection{Zircaloy 2}

Zircaloy 2 was chosen to replace SS in BWR cladding applications. The Zircaloy 2 alloy has about $98 \%$ zirconium with alloy additions of tin, iron, chrome and nickel. Zircaloy 2 is generically categorized as grade R60802 in ASTM B811 and B353 and is used extensively for BWR cladding. Prior to 1991 the applicable ASTM specification was B353 before being replaced by ASTM B811. Table 5 lists the nominal alloy element levels for Zircaloy 2.

\subsubsection{Zircaloy 4 (high tin)}

Zircaloy 4 is defined by ASTM B811 grade R60804, although some vendors produce Zircaloy 4 cladding per their own specifications which provide for more specific controls. Prior to 1991, the applicable ASTM specification was B353 before being replaced by ASTM B811.

Zircaloy 4 is similar to Zircaloy 2 except Zircaloy 4 has the nickel removed to reduce hydrogen absorption in the PWR environment. To offset the strength reduction more iron was added to the Zircaloy 4 version. ${ }^{7}$

The Zircaloy 4 specification has a tin range of 1.25 to $1.7 \%$. The initial versions of Zircaloy 4 were produced with tin levels at $1.55 \%$ or nearer the upper tin limit. Also the level of carbon was permitted to be $270 \mathrm{ppm}$ maximum. Carbon is an impurity, but it has positive effects in microstructure control and at high levels has negative effects on corrosion resistance and growth. In the late 1980s, improved versions of Zircaloy 4 were introduced that provided tighter controls on tin and carbon in addition to other parameters, such as annealing. The typical alloy element levels for Zircaloy 4 are shown in Table 5.

\subsubsection{Current Domestic Cladding Alloy Types}

There are primarily four cladding alloy types currently operating in large quantities and in multiple fuel regions of commercial reactors. They are lined Zircaloy 2, improved Zircaloy 4, $\mathrm{M} 5^{\circledR}$ and, ZIRLO ${ }^{\mathrm{TM}}$. Optimized ZIRLO ${ }^{\mathrm{TM}}$ is also being introduced for very high duty applications and is present as multiple regions in a few reactors. The typical alloy element levels for these alloys are also shown in Table 5. 


\subsubsection{Zircaloy 2 - Lined}

The bulk of the BWR fuels are now operating with lined Zircaloy 2 cladding. The Zircaloy 2 clad is similar to the earlier versions but has iron and nickel adjusted towards the upper limits and tin adjusted towards the lower limit of the ASTM range. ${ }^{8}$

The ID liner which is "softer" than the base clad is pure zirconium or zirconium with small alloy additions. The liner is designed to accommodate the strains resulting from pellet expansions with reactor core power level changes along with mitigating stress corrosion assisted cracking on the clad ID surface; a condition referred to as PCI (pellet clad interaction) failures.

\subsubsection{Low Tin - Improved Zircaloy 4}

With the increase in fuel duty and burn up more margins to the corrosion and hydrogen design limits were needed for cladding. For PWRs applications Zircaloy 4 was improved with a reduction in the tin level aim, improved controls over some impurity/alloy elements such as carbon and nitrogen and an optimization of the anneal process to produce a consistent and desirable microstructure, referred to as A-Time control. The improved versions of Zircaloy 4 were introduced by fuel vendors starting in the late 1980's. The improved corrosion resistance of this material supported use to higher burn-up and with higher duties thus while a more robust alloy than the standard Zircaloy 4, at the EOL some of the fuel rod cladding has oxide and hydrogen levels near the design limits. ${ }^{9-11}$

\subsubsection{3 $M 5^{\circledR} 12$}

AREVA introduced the Alloy M $5^{\circledR}$ for fuel applications in the 1990 's with 16 U.S. commercial reactors having used or are using $\mathrm{M} 5^{\circledR}$ clad fuel which is now considered the AREVA PWR reference alloy. $\mathrm{M} 5{ }^{\circledR}$ is an alloy from the $\mathrm{Zr}-1 \% \mathrm{Nb}$ family having no alloy additions of tin and chrome like the Zircaloys and only minor amounts of iron (400 ppm) and oxygen (1400 ppm). Sulfur at about $25 \mathrm{ppm}$ is also added to improve the creep strength. Performance data indicates that in reactor operation the clad oxidation is significantly reduced compared to Zircaloy 4 for the same burn up conditions.

\subsubsection{ZIRLO $O^{\operatorname{tm} 13}$}

ZIRLO is a $\mathrm{Zr}-1 \% \mathrm{Nb}-1 \% \mathrm{Sn}-0.1 \%$ Fe alloy with the typical addition of $0.12 \% \mathrm{O}$. Westinghouse introduced ZIRLO in early 1990's as a replacement for Improved Zircaloy 4 for higher duty operations and it has become the reference alloy for Westinghouse fuel cladding with most if not all of the Westinghouse fueled domestic reactors using ZIRLO cladding. ZIRLO has enhanced corrosion resistance and lower hydrogen levels compared to Zircaloy 4 for equivalent burn ups and fuel duties. With the tin and iron additions ZIRLO is a robust alloy that is resistant to coolant chemistry variation effects. ZIRLO and M5 are also resistant to oxide spalling which is observed in some high burn up Zircaloy 4 fuel. 


\subsubsection{Optimized ZIRLO ${ }^{\text {tm } 14}$}

Westinghouse developed Optimized ZIRLO to provided added performance margin for high duty fuel applications. Optimized ZIRLO has the basic characteristics of standard ZIRLO but has a $35 \%$ reduced tin level to a range of $0.6 \%$ to $0.8 \%$ while maintaining the niobium at $1 \%$ and iron at $0.1 \%$ levels. The reduced tin has shown improved corrosion resistance compared to standard ZIRLO with peak oxides less than 40 microns at discharge burn ups of 62 GWD/MTU. In 2005, the NRC approved optimized ZIRLO for use in reactor fuel and as of 2010 the alloy is in use as regions in a few commercial reactors.

\subsubsection{Potential New Advanced Metal Alloy Cladding}

The fuel vendors are evaluating other advanced alloys for future applications. Currently the new alloys are being used in reactor in test assemblies and thus do not represent a significant quantity for storage consideration. As new alloys are developed it is appropriate that their dry storage characteristics be included as part of their data generation scope.

\section{COMMERCIAL STORAGE OF DISCHARGED FUEL}

Used nuclear fuel is stored predominantly at 83 locations throughout the United States. These locations include reactor storage pools, independent spent fuel storage installations, national laboratories, and defense sites. These locations are detailed on Table 6 and shown graphically in Figure 4.

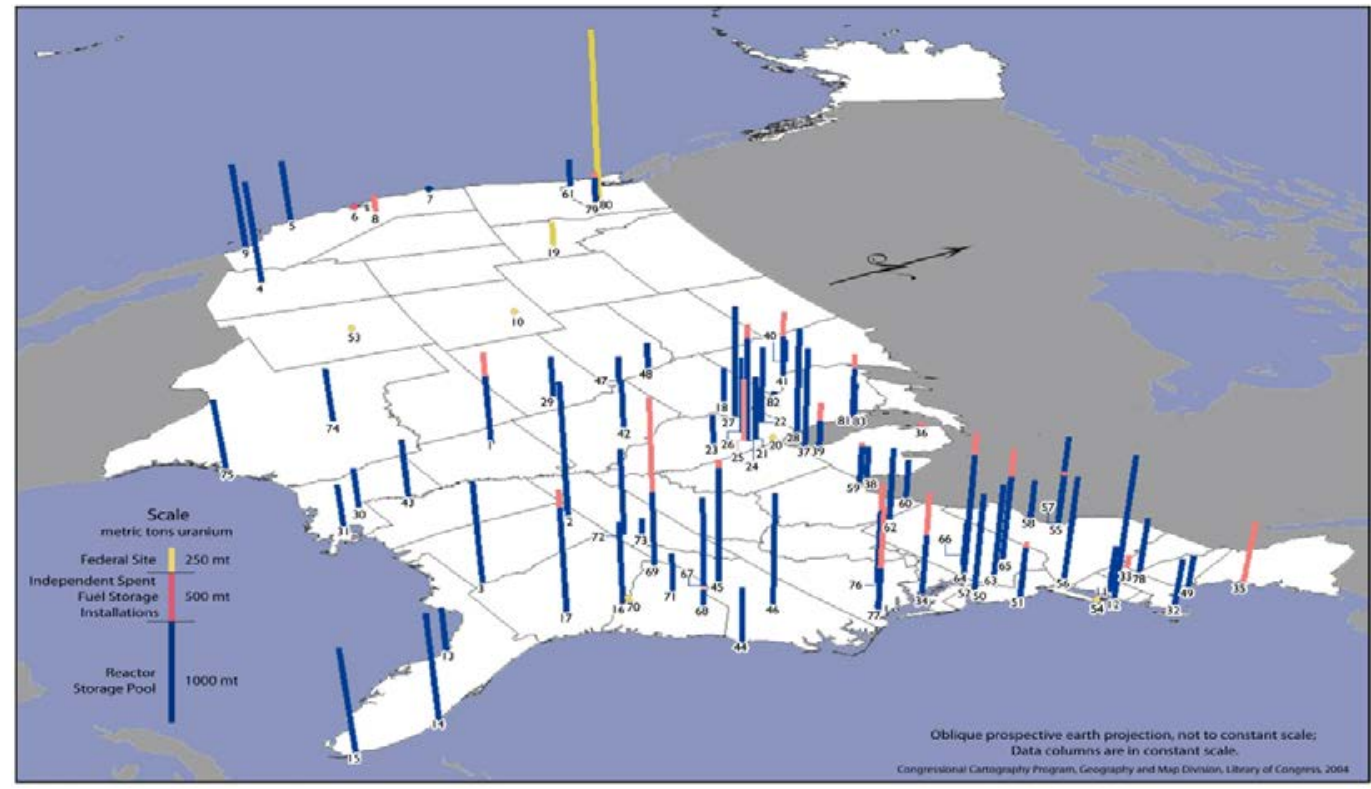

Figure 4 Reactor Storage Pools, Independent Spent Fuel Storage Installations, Federal, and Other Sites. ${ }^{15}$ 


\subsection{Commercial Wet Storage in Fuel Pools}

Every operating reactor has a fuel pool for temporary storage of used assemblies discharged from the reactor. Figure 5 presents a picture of the used fuel pool at Yankee Rowe. During operation, about one-quarter to one-third of the total fuel load from the reactor is spent and removed from the reactor every 12-18 months and replaced with fresh fuel. The discharged fuel assemblies will each have experienced different exposure conditions (e.g., power, temperature, neutron flux, burnup, etc.) dependent upon its location within the core during exposure and total exposure time. Each assembly will therefore be unique in composition and mechanical characteristics. Table 7 provides the range of used fuel burnup for the assemblies discharged by the reactor.

Over the last few decades of commercial reactor operation has resulted spent fuel pools that have been reaching capacity. Reracking of the spent fuel pool grids and fuel rod consolidation operations undertaken by the utilities has significantly increased fuel pool capacity at existing reactor fuel pools. However, these activities have only postponed the inevitable situation of having full fuel pools.

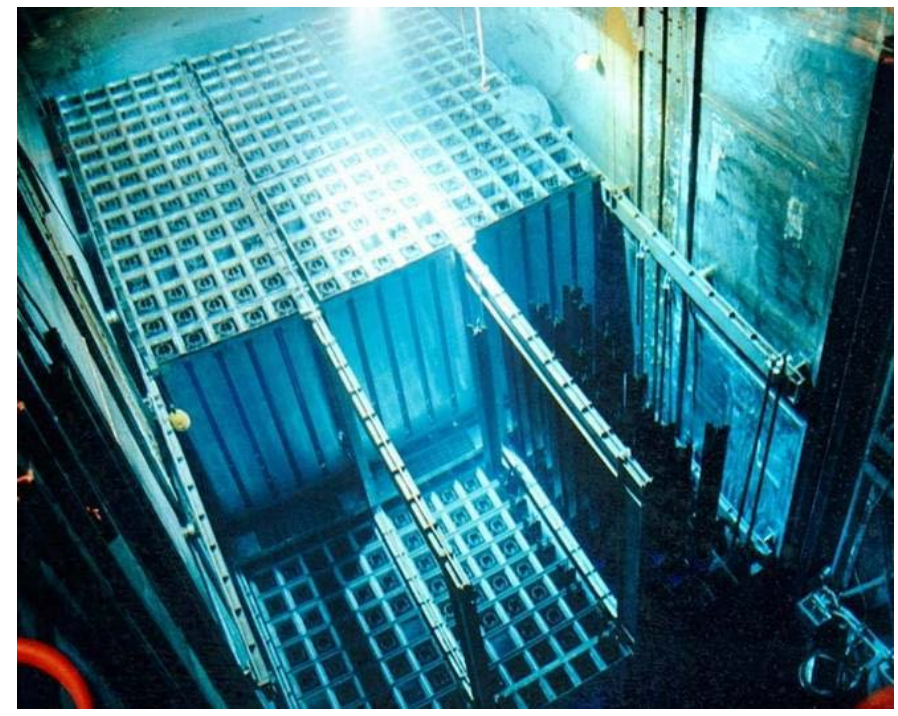

Figure 5 Used Fuel Pool at Yankee Rowe.

Table 8 lists the fuel pool types and capacities by utility, and Table 9 provides the year that each of the commercial nuclear plants in the United States will run out of on-site storage space in their fuel pools for discharged nuclear fuel. Figure 6 shows the number of operating reactors are already storing used fuel quantities that exceed their capacity with time. As reactor fuel pool inventories have approached capacity, utilities have been forced to utilize alternative used fuel storage strategies. These used fuel storage strategies include expansion of existing fuel pools, construction of new fuel pools, and the incorporation of independent wet or dry storage facilities. These storage facilities have been constructed both at operating reactors and at other facilities that are not collocated with operating reactors. The lone away-from-reactor (AFR) storage 
facility that utilizes wet storage technology for storage of used nuclear fuel in the U.S. is the GE Morris Operation in Illinois. The Morris facility, operational since 1972, was designed to receive one year cooled used uranium dioxide fuel. The storage capacity of the facility was increased from 100 to 750 tonnes heavy metal in 1976 by installation of high density fuel storage racks and changes in fuel handling and support systems.

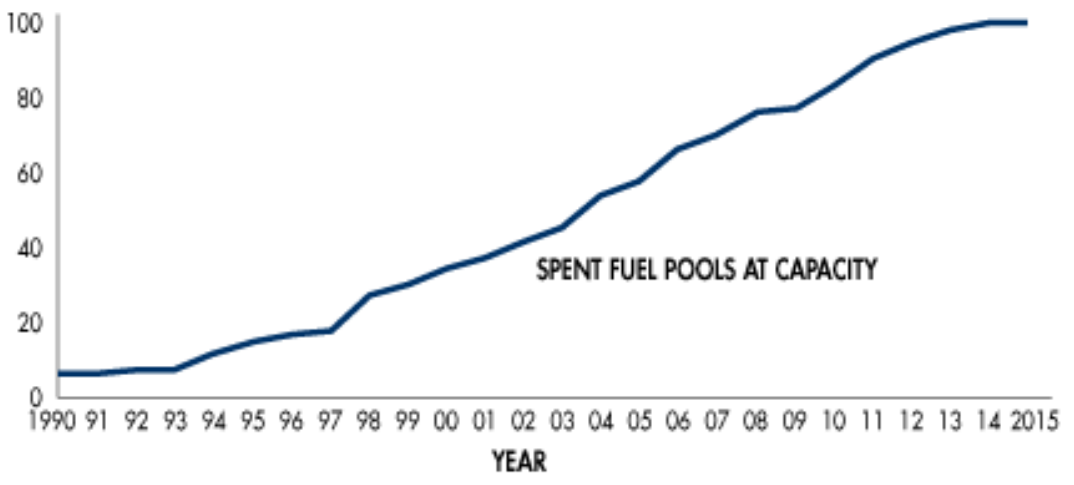

Note: All operating nuclear power reoctors are storing used fuel under NRC license in spent fuel pools. Some operating nuclear reoctors are using dry cosk storage. Information is based on loss of full-core reserve in the spent fuel pools.

Source: Energy Resources Infernational and DOE/RW-0431 - Revision 1

Figure 6 Cumulative Number of Filled Fuel Pools

The remainder of away from reactor storage facilities in the U.S. utilizes one of a number of licensed dry storage system technologies. Reference 17 provides an excellent description of licensed dry storage systems. These dry storage systems are generally incorporated in ISFSIs. The ISFSIs may be collocated with operational reactors, located independent of any reactor, or located on the site of shutdown or decommissioned reactor facilities. Figure 7 provides a map of the ISFSIs located in the U.S. as of May 2009. 


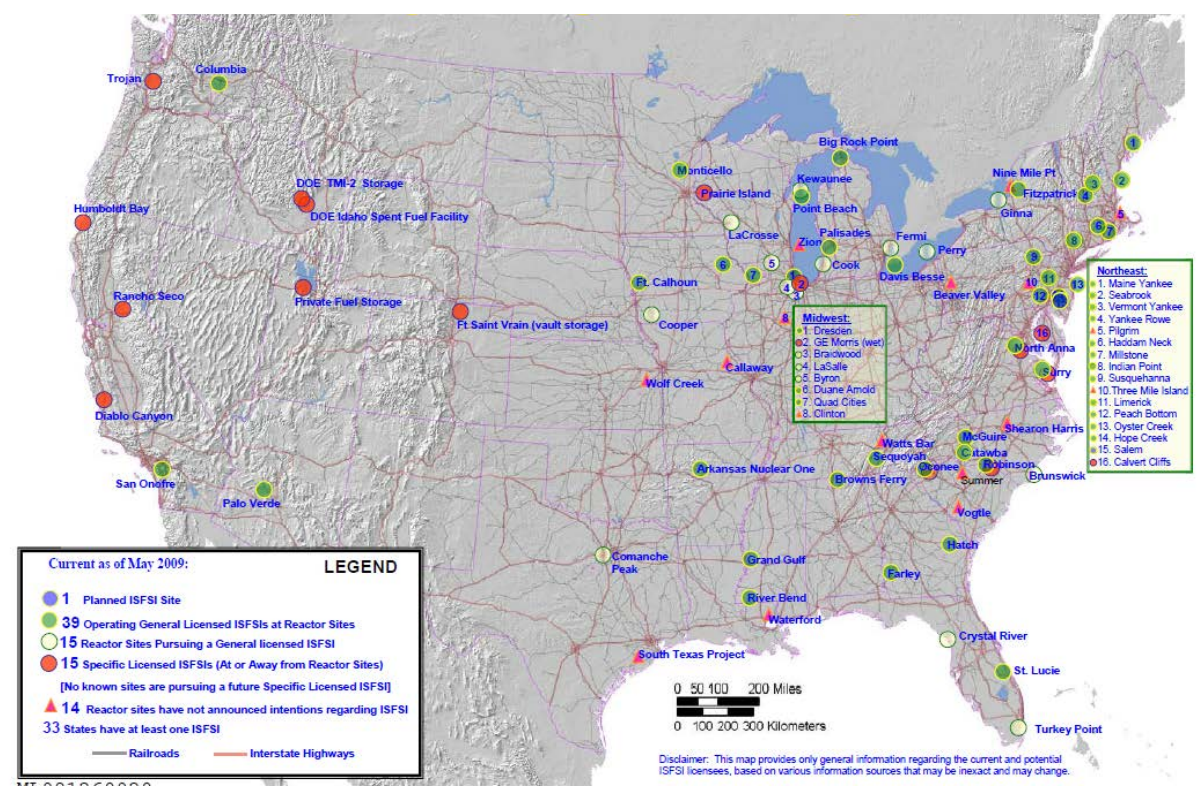

Figure 7 U.S. Independent Spent Fuel Storage Installations.

\subsection{Commercial Dry Storage of Discharged Fuel}

As the number of reactor fuel pools that has reached capacity has increased, the number and types of dry storage facilities in operation and under construction has increased. The past 10-15 years has seen a significant increase in the development and construction of dry storage capacity. This increasing need for dry storage systems has lead to development of new concepts for dualpurpose (storage and transport) or multi-purpose (storage, transport and disposal) applications. Dry storage systems allow for a scalable solution to the problem of used fuel storage. These systems generally have lower operating costs. Capital costs for these systems may be dispersed over time by allowing additional storage capacity to be constructed on an as-needed basis. Figure 8 shows the dual-purpose dry-storage facility at Connecticut Yankee. This concept utilized individual dry storage cask in overpacks that are stored vertically on a pad, while Figure 9 shows the vault storage concept in which the dry storage cask is stored horizontally in individual vaults. Tables 10 and 11 provide the current inventory of used fuel in dry storage cask by cask vendor and by utility, respectively. 


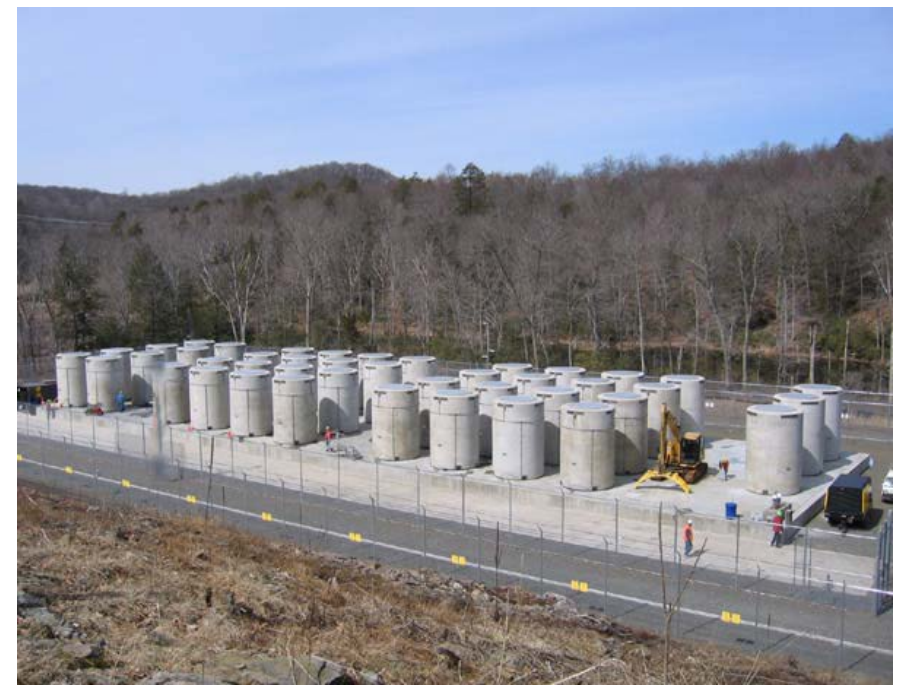

Figure 8 Connecticut Yankee Dual-Purpose Dry Storage Facility.

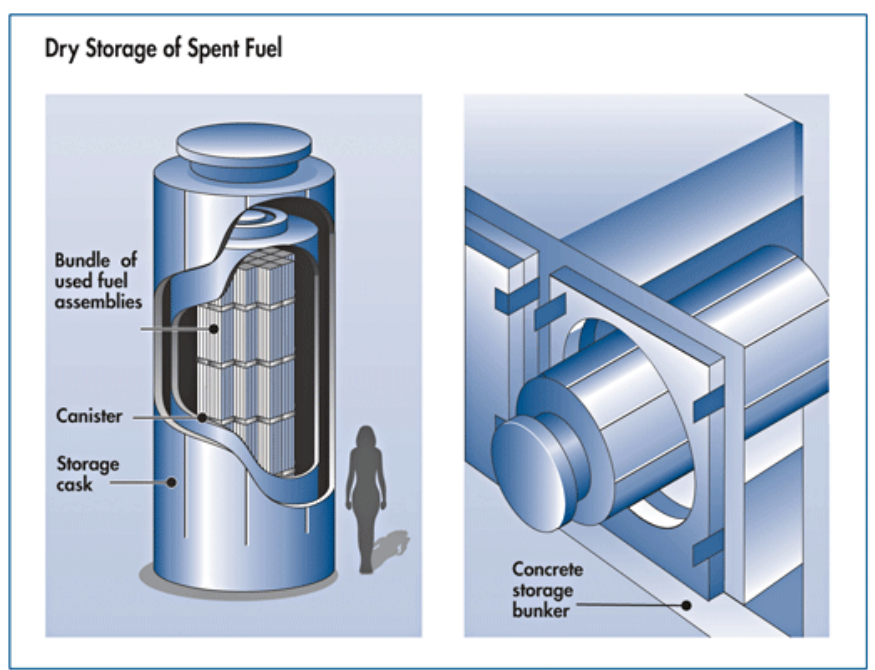

Figure 9 Used Fuel Dry Storage Systems ${ }^{18}$

\subsection{Used Nuclear Fuel Storage at Shutdown Reactors}

As the U.S. reactors reach their license termination date, the utility owner may apply for a license extension for the reactor. Table 12 provides general license termination data for U.S. commercial power reactors. Data is provided on the initial license termination dates along with information on the status of license extension applications, where applicable. Those reactors that are not granted a license extension, or those for which a license extension has not been sought, are then placed in a shutdown mode awaiting decommissioning. 
There are fifteen shutdown reactors at fourteen sites in ten states that are currently storing used nuclear fuel in either wet or dry storage conditions. Table 13 provides a list of shutdown reactors that had a power rating greater than $100 \mathrm{MW}$. After shutdown, the reactors are scheduled for decommissioning. Table 14 provides the decommissioning status of shutdown power reactors. In some cases, shutdown reactors are decommissioned without complete deinventory of the used fuel stores at the site. The data in Table 14 includes the quantities and locations (in metric tons uranium) of the stored used fuel at the shutdown reactors. Four of these locations have operating reactors and two of these locations utilize pool storage. There are currently six facilities that have been completely decommissioned, sans deinventory. These facilities are termed "orphan" sites, due to the presence of independent spent fuel storage installations, without a collocated reactor or a fuel pool in which to unload the storage casks.

\section{FEDERAL STORAGE OF DISCHARGED COMMERCIAL FUEL}

Spent nuclear fuel at federal storage is principally stored at 4 locations throughout the United States. These include defense and non defense federal facilities (national laboratories and defense weapons sites ${ }^{19}$ ). Commercial nuclear fuel at us facilities includes scrap or segmented rods in canister, assembly, rods and rod array, element, and debris. Depending upon the facility, the spent fuel may either be pool or dry stored. With the exception of Savannah River Site that maintains and operates a wet storage facility, all the fuel throughout the federal facilities is kept in dry storage system. Detailed information by federal facility, type of fuel, cladding and others is included in Tables 16 - 19.

In addition to national laboratories and defense weapons sites, the B\&W Lynchburg Technology Center facility and a number of universities that have reported small quantities of used fuel material that has been discharged from commercial power reactors. Tables 20 \& 21 details the current inventory of used fuel from commercial power reactors and Table 22 provides a list of utilities reporting used fuel from commercial power reactors.

\section{POTENTIAL COLLABORATION BETWEEN THE DEPARTMENT AND INDUSTRY}

The UFD Campaign requires information from industry on the inventory of used nuclear fuel and material for R\&D effort and for a long-term demonstration effort. The information needed includes specific data on the exposure, storage, and treatment of used fuel rods and assemblies from power reactors in the U.S. The materials needs are two-fold. The R\&D effort requires small quantities of used fuel materials, on the order of a couple to a few rods. These fuel rods will be extracted from high-burnup used fuel assemblies and from both PWRs and BWRs. The rods will be destructively examined and tested to provide data on the physical, mechanical, structural, chemical, and radiochemical characteristics of used in conditions consistent with extended dry storage of the fuel. The full-scale demonstration effort, named the Testing and Evaluation Facility (TEF), will require a number of complete used fuel assemblies, sufficient to fill multiple, up to $\sim 4$, dry storage casks. These will be both high and low burnup fuel assemblies taken from both PWRs and BWRs. The assemblies will be loaded in instrumented dry storage cask to allow for a long-term demonstration effort. The instrumented cask will 
provide data that is crucial to demonstrating the condition of used high burnup fuel during extended dry storage.

A framework is being developed for cooperation between the nuclear power industry and the Department of Energy through which both information and material related to used nuclear fuel may be shared. This framework will provide the mechanisms by which the information on used fuel inventory presented in the current report may be updated and expanded. In addition, the framework will provide the mechanisms by which DOE will secure both lab-scale quantities necessary for the UFD R\&D efforts and large-scale quantities necessary for the full-scale demonstration project, TEF, from nuclear power industry.

Negotiations between DOE and industry are ongoing. Currently, no additional inventory information has been exchanged. In addition, no commitment has been secured from any utility concerning the provision of material, either rods or assemblies, for use in the UFD campaign. However, it is expected that continued efforts in these negotiations will result in a mutually beneficial framework for cooperation between DOE and the fuel owners.

\section{CONCLUSION}

This report provides the inventory of used nuclear fuel being stored in the United States based upon publicly available resources. It includes the most current projections of used fuel discharges from operating reactors. It includes a status of negotiations between DOE and industry. These negotiations are ongoing and are expected to result in a framework for cooperation between the Department and industry in which industry will provide and specific information on used fuel inventory and the Department will compensate industry for the material required for $\mathrm{R} \& \mathrm{D}$ and TEF activities.

\section{REFERENCES}

1 Courtesy of EuroNuclear, "What is a Nuclear Reactor? European Nuclear Society," webpage, http://www.euronuclear.org/info/energy-uses.htm

2 Courtesy of NRC. http://www.nrc.gov/reading-rm/basic-ref/students/animated-bwr.html

3 Glasstone \& Sesonske 1994, pp. 21

4 Courtesy of NRC. http://www.nrc.gov/reading-rm/basic-ref/students/animated-bwr.html

5 Courtesy of Princeton University:

http://blogs.princeton.edu/chm333/f2006/nuclear/05_fuel_fabrication/01_types_of_fuel/

6 Reich, W.J., Moore, R.S., and Notz, K.J. Distribution of Characteristics of LWR Spent Fuel ORNL/TM 11670, January 1991.

7 Schemel. J.H. Zirconium Alloy Fuel Clad Tubing Engineering Guide, Sandvik Special Metals Corporation , December 1989. 
8 Graham, R.A. and Eucken, C.M., Controlled Composition Zircaloy-2 Uniform Corrosion Resistance, ASTM STP 1132, $9^{\text {th }}$ International Symposium on Zirconium in the Nuclear Industry; 1991 pp. 279-303.

9 Garde, A.M.et.al., Corrosion Behavior of Zircaloy-4 Cladding with Varying Tin Content in High-Temperature Pressurized Water Reactors; ASTM STP 1245, $10^{\text {th }}$ International Symposium on Zirconium in the Nuclear Industry; 1994 pp. 760-778.

10 Mardon, J.P. et.al., Optimization of PWR Behavior of Stress-relieved Zircaloy-4 Cladding Tubes by Improving the Manufacturing and Inspection Process; ASTM STP 1245, $10^{\text {th }}$ International Symposium on Zirconium in the Nuclear Industry; 1994 pp. 328-348.

11 Sabol, G. et.al. In-Reactor Corrosion Performance of ZIRLO ${ }^{\text {tm }}$ and Zircaloy 4; ASTM STP $1254,10^{\text {th }}$ International Symposium on Zirconium in the Nuclear Industry, 1994 pp. 724-744.

12 Mardon, J.P., Garner, G.L., and Hoffmann, P.B. M5 ${ }^{\circledR}$, a Breakthrough in Zr Alloy 2010 LWR Fuel Performance Meeting Top Fuel ; September 2010 Orlando Florida.

13 Sabol, G. et.al.; Development of a Cladding Alloy for High Burnup ; ASTM STP $10238^{\text {th }}$ International Symposium on Zirconium in the Nuclear Industry, 1989 pp 227-244.

14 Wikmark, G. et.al., Cladding to Sustain Corrosion, Creep and Growth at High Burn-ups; Nuclear Engineering and technology, Vol 41 No.2 March 2009-Special Issue on the Water Reactor Fuel Performance Meeting 2008. CRS RS22001, updated 2004.

16 Courtesy of www.nukeworker

17 Industry Spent Fuel Storage Handbook, EPRI Report Number 1021048 (July 2010).

18 Courtesy of NRC; http://www.nrc.gov/reading-rm/doc-collections/fact-sheets/dry-cask-storage.html.

19 Spent Nuclear Fuel Storage Locations and Inventory , Anthony Andrews Specialist in Industrial Engineering and Infrastructure Policy Resources, Science, and Industry Division, CRS Report to Congress Order Code RS22001 Updated 2005. 


\section{Appendix A}

\section{Tables}




\section{TABLES}

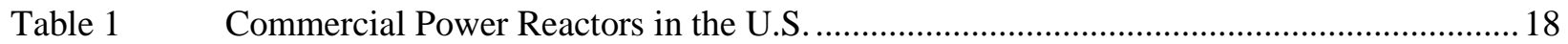

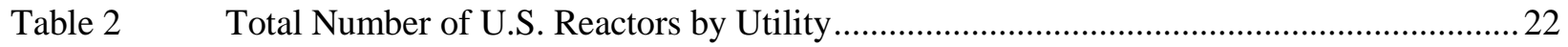

Table $3 \quad$ Total Number of Reactors in U.S. by Type..................................................................... 22

Table $4 \quad$ Fuel Assembly Geometry by Assembly Design Type.......................................................23

Table $5 \quad$ Nominal Compositions of Alloys Used as Nuclear Fuel Cladding ................................... 23

Table 6 Reactor Storage Pools, Independent Spent Fuel Storage Installations, Federal, and Other

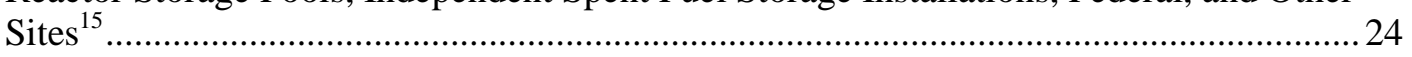

Table $7 \quad$ Range of Burnup for Used Nuclear Fuel by Reactor........................................................ 25

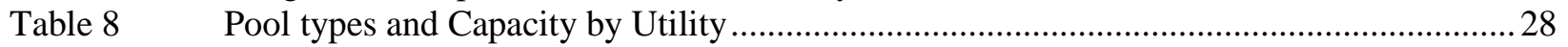

Table $9 \quad$ Status of Used Fuel Storage at Commercial Nuclear Power Plants. (NEI) ......................... 32

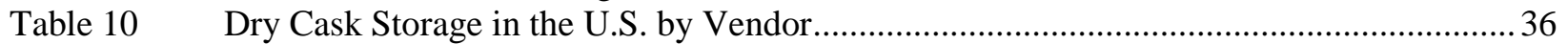

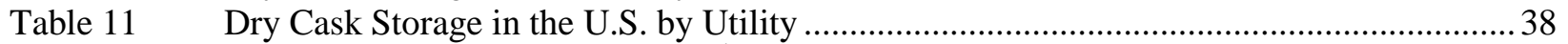

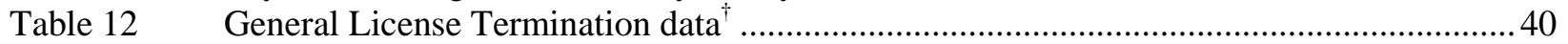

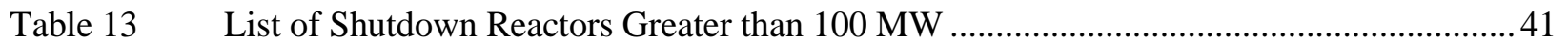

Table 14 Decommissioning Status for Shutdown Power Reactors ................................................... 42

Table 15 Cumulative Commercial Reactor Discharges..................................................................... 43

Table 16 Commercial Inventory of Uranium Oxide Fuel being Stored Dry at Argonne National

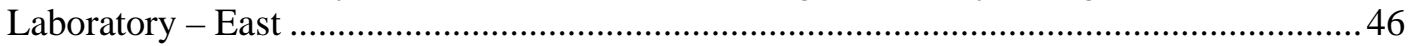

Table 17 Commercial Inventory of Uranium Oxide Fuel being Stored Dry at Hanford

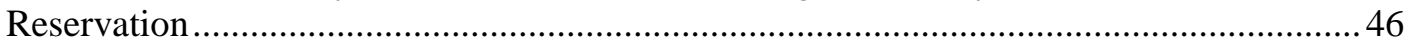

Table 18 Commercial Inventory of Uranium Oxide Fuel being Stored Dry at Idaho National

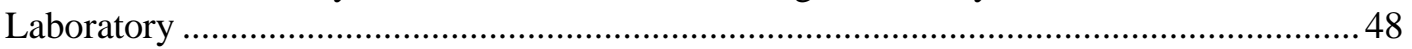

Table 19 Commercial Inventory of Uranium Oxide Fuel being Stored Wet at the Savannah River

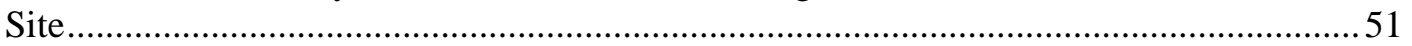

Table 20 Commercial Fuel Inventory of Uranium Oxide Fuel being Stored Dry at B\&W Lynchburg Technology Center........................................................................................ 51

Table 21 Supplemental Information on Commercial Fuel Inventory at B\&W Lynchburg

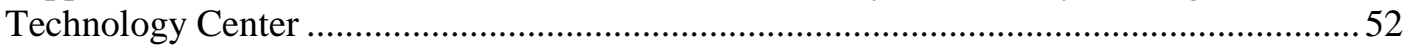

Table 22 University Research Reactors Reporting Spent Fuel (CRS) ............................................ 53 
Table 1 Commercial Power Reactors in the U.S.

\begin{tabular}{|c|c|c|c|c|c|}
\hline Facility & Process & $\begin{array}{c}\text { Capacity } \\
\text { MW }_{\mathrm{e}} \\
\text { net }\end{array}$ & Current Status & $\begin{array}{l}\text { Start } \\
\text { Year }\end{array}$ & Owner \\
\hline Allens Creek-2 & BWR & 1150 & $\begin{array}{l}\text { Suspended } \\
\text { indefinitely/Cancelled }\end{array}$ & & \\
\hline Argonne EBWR & BWR & 5 & Shut down & 1956 & US Department of Energy (DOE) \\
\hline $\begin{array}{l}\text { Arkansas Nuclear- } \\
1\end{array}$ & PWR & 836 & Operating & 1974 & Entergy Nuclear \\
\hline $\begin{array}{l}\text { Arkansas Nuclear- } \\
2\end{array}$ & PWR & 965 & Operating & 1980 & Entergy Nuclear \\
\hline Bayside & BWR & 1000 & $\begin{array}{l}\text { Suspended } \\
\text { indefinitely/Cancelled }\end{array}$ & & Atlantic City Electric \\
\hline Beaver Valley-1 & PWR & 810 & Operating & 1976 & First Energy \\
\hline Beaver Valley-2 & PWR & 833 & Operating & 1987 & First Energy \\
\hline Bellefonte-1 & PWR & 1213 & $\begin{array}{l}\text { Suspended } \\
\text { indefinitely/Cancelled }\end{array}$ & & Tennessee Valley Authority (TVA) \\
\hline Bellefonte-2 & PWR & 1213 & $\begin{array}{l}\text { Suspended } \\
\text { indefinitely/Cancelled }\end{array}$ & & Tennessee Valley Authority (TVA) \\
\hline Big Rock Point & BWR & 67 & Shut down & 1963 & Consumers Energy \\
\hline Bonus (Demo) & BWR & 17 & Shut down & & US Department of Energy (DOE) \\
\hline Braidwood-1 & PWR & 1120 & Operating & 1988 & Exelon Nuclear Co \\
\hline Braidwood-2 & PWR & 1120 & Operating & 1988 & Exelon Nuclear Co \\
\hline Browns Ferry-1 & BWR & 1065 & Operating & 1974 & Tennessee Valley Authority (TVA) \\
\hline Browns Ferry-2 & BWR & 1118 & Operating & 1975 & Tennessee Valley Authority (TVA) \\
\hline Browns Ferry-3 & BWR & 1118 & Operating & 1977 & Tennessee Valley Authority (TVA) \\
\hline Brunswick-1 & BWR & 820 & Operating & 1977 & Progress Energy Corp \\
\hline Brunswick-2 & BWR & 811 & Operating & 1975 & Progress Energy Corp \\
\hline Byron-1 & PWR & 1105 & Operating & 1985 & Exelon Nuclear Co \\
\hline Byron-2 & PWR & 1105 & Operating & 1987 & Exelon Nuclear Co \\
\hline Callaway-1 & PWR & 1235 & Operating & 1984 & Ameren \\
\hline Calvert Cliffs-1 & PWR & 825 & Operating & 1975 & Constellation Energy \\
\hline Calvert Cliffs-2 & PWR & 825 & Operating & 1977 & Constellation Energy \\
\hline Carolinas CVTR & PHWR & 17 & Shut down & 1963 & CVNPA \\
\hline Catawba-1 & PWR & 1129 & Operating & 1985 & Duke Power Co \\
\hline Catawba-2 & PWR & 1129 & Operating & 1986 & Duke Power Co \\
\hline Cherokee-1 & PWR & 1280 & Construction suspended & & Duke Power Co \\
\hline Cherokee-2 & PWR & 1280 & Construction suspended & & Duke Power Co \\
\hline Clinch River & FBR & 350 & $\begin{array}{l}\text { Suspended } \\
\text { indefinitely/Cancelled }\end{array}$ & & Tennessee Valley Authority (TVA) \\
\hline Clinton-1 & BWR & 930 & Operating & 1987 & AmerGen Energy Co \\
\hline Columbia (WNP-2) & BWR & 1150 & Operating & 1984 & Energy Northwest \\
\hline Comanche Peak-1 & PWR & 1150 & Operating & 1990 & TXU Electric Co \\
\hline Comanche Peak-2 & PWR & 1150 & Operating & 1993 & TXU Electric Co \\
\hline Cooper & BWR & 764 & Operating & 1974 & Nebraska Public Power District (NPPD) \\
\hline Crystal River-3 & PWR & 868 & Operating & 1977 & Progress Energy Corp \\
\hline Crystal River-4 & PWR & 910 & $\begin{array}{l}\text { Suspended } \\
\text { indefinitely/Cancelled }\end{array}$ & & Progress Energy Corp \\
\hline Davis Besse- 1 & PWR & 877 & Operating & 1978 & First Energy \\
\hline Diablo Canyon-1 & PWR & 1130 & Operating & 1985 & Pacific Gas and Electric Co (PG\&E) \\
\hline
\end{tabular}




\begin{tabular}{|c|c|c|c|c|c|}
\hline Facility & Process & $\begin{array}{c}\text { Capacity } \\
\text { MW }_{\mathrm{e}} \\
\text { net }\end{array}$ & Current Status & $\begin{array}{l}\text { Start } \\
\text { Year }\end{array}$ & Owner \\
\hline Diablo Canyon-2 & PWR & 1160 & Operating & 1986 & Pacific Gas and Electric Co (PG\&E) \\
\hline Donald Cook-1 & PWR & 1020 & Operating & 1975 & Indiana Michigan Power Co \\
\hline Donald Cook-2 & PWR & 1108 & Operating & 1978 & Indiana Michigan Power Co \\
\hline Dresden-1 & BWR & 200 & Shut down & 1960 & Commonwealth Edison (CommEd) \\
\hline Dresden-2 & BWR & 912 & Operating & 1970 & Exelon Nuclear Co \\
\hline Dresden-3 & BWR & 794 & Operating & 1971 & Exelon Nuclear Co \\
\hline Duane Arnold-1 & BWR & 600 & Operating & 1975 & FPL Group \\
\hline EBR-II (test) & FBR & 17 & Shut down & 1964 & Argonne National Laboratory (ANL) \\
\hline Elk River & BWR & 22 & Shut down & 1964 & US Department of Energy (DOE) \\
\hline Enrico Fermi-1 & FBR & 61 & Shut down & 1966 & PRDC \\
\hline Enrico Fermi-2 & BWR & 1139 & Operating & 1988 & Detroit Edison Co \\
\hline Farley-1 & PWR & 828 & Operating & 1977 & Alabama Power \\
\hline Farley-2 & PWR & 838 & Operating & 1981 & Alabama Power \\
\hline FitzPatrick & BWR & 780 & Operating & 1975 & Entergy Nuclear \\
\hline Fort Calhoun-1 & PWR & 485 & Operating & 1974 & Omaha Public Power District (OPPD) \\
\hline Fort St Vrain & HTGR & 330 & Shut down & 1979 & Public Service Co of Colorado (PSCC) \\
\hline Grand Gulf-1 & BWR & 1204 & Operating & 1985 & Entergy Nuclear \\
\hline H B Robinson-2 & PWR & 683 & Operating & 1971 & Progress Energy Corp \\
\hline Haddam Neck & PWR & 590 & Shut down & 1968 & Northern Utilities \\
\hline Hallam & Na-graphite & 75 & Shut down & 1963 & DOE/NPPD \\
\hline Hartsville-A1 & BWR & 1206 & $\begin{array}{l}\text { Suspended } \\
\text { indefinitely/Cancelled }\end{array}$ & & Tennessee Valley Authority (TVA) \\
\hline Hartsville-A2 & BWR & 1206 & $\begin{array}{l}\text { Suspended } \\
\text { indefinitely/Cancelled }\end{array}$ & & Tennessee Valley Authority (TVA) \\
\hline Hatch-1 & BWR & 863 & Operating & 1975 & Southern Nuclear Operating Co \\
\hline Hatch-2 & BWR & 878 & Operating & 1979 & Southern Nuclear Operating Co \\
\hline Hope Creek-1 & BWR & 1031 & Operating & 1986 & $\begin{array}{l}\text { Public Service Electric and Gas Co } \\
\text { (PSEG) }\end{array}$ \\
\hline Humboldt Bay & BWR & 63 & Shut down & 1963 & Pacific Gas and Electric Co (PG\&E) \\
\hline Indian Point-1 & PWR & 255 & Shut down & 1962 & Entergy Corp \\
\hline Indian Point-2 & PWR & 975 & Operating & 1974 & Entergy Nuclear \\
\hline Indian Point-3 & PWR & 979 & Operating & 1976 & Entergy Nuclear \\
\hline Kewaunee & PWR & 545 & Operating & 1974 & Dominion Resources \\
\hline LaCrosse & BWR & 50 & Shut down & 1969 & DPC \\
\hline LaSalle-1 & BWR & 1078 & Operating & 1984 & Exelon Nuclear Co \\
\hline LaSalle-2 & BWR & 1078 & Operating & 1984 & Exelon Nuclear Co \\
\hline Limerick-1 & BWR & 1200 & Operating & 1986 & Exelon Nuclear Co \\
\hline Limerick-2 & BWR & 1200 & Operating & 1990 & Exelon Nuclear Co \\
\hline Maine Yankee & PWR & 870 & Shut down & 1972 & Maine Yankee Atomic Power Co \\
\hline McGuire-1 & PWR & 1100 & Operating & 1981 & Duke Power Co \\
\hline McGuire-2 & PWR & 1100 & Operating & 1984 & Duke Power Co \\
\hline Midland-1 & PWR & 492 & $\begin{array}{l}\text { Suspended } \\
\text { indefinitely/Cancelled }\end{array}$ & & Consumers Power Corp \\
\hline Midland-2 & PWR & 816 & $\begin{array}{l}\text { Suspended } \\
\text { indefinitely/Cancelled }\end{array}$ & & Consumers Power Corp \\
\hline Millstone-1 & BWR & 660 & Shut down & 1971 & Northern Utilities \\
\hline Millstone-2 & PWR & 875 & Operating & 1975 & Dominion Virginia Power \\
\hline
\end{tabular}


March 31, 2011

\begin{tabular}{|c|c|c|c|c|c|}
\hline Facility & Process & $\begin{array}{c}\text { Capacity } \\
\text { MW }_{\mathrm{e}} \\
\text { net }\end{array}$ & Current Status & $\begin{array}{l}\text { Start } \\
\text { Year }\end{array}$ & Owner \\
\hline Millstone-3 & PWR & 1152 & Operating & 1986 & Dominion Virginia Power \\
\hline Monticello & BWR & 593 & Operating & 1971 & Xcel Energy \\
\hline Nine Mile Point-1 & BWR & 610 & Operating & 1969 & Constellation Energy \\
\hline Nine Mile Point-2 & BWR & 1143 & Operating & 1988 & Constellation Energy \\
\hline North Anna-1 & PWR & 925 & Operating & 1978 & Dominion Virginia Power \\
\hline North Anna-2 & PWR & 917 & Operating & 1980 & Dominion Virginia Power \\
\hline Oconee-1 & PWR & 846 & Operating & 1973 & Duke Power Co \\
\hline Oconee-2 & PWR & 846 & Operating & 1974 & Duke Power Co \\
\hline Oconee-3 & PWR & 846 & Operating & 1974 & Duke Power Co \\
\hline Oyster Creek & BWR & 610 & Operating & 1969 & AmerGen Energy Co \\
\hline Palisades & PWR & 789 & Operating & 1971 & Consumers Energy \\
\hline Palo Verde-1 & PWR & 1243 & Operating & 1986 & Arizona Nuclear Power Project (ANPP) \\
\hline Palo Verde-2 & PWR & 1243 & Operating & 1986 & Arizona Nuclear Power Project (ANPP) \\
\hline Palo Verde-3 & PWR & 1247 & Operating & 1988 & Arizona Nuclear Power Project (ANPP) \\
\hline $\begin{array}{l}\text { Pathfinder test } \\
\text { reactor }\end{array}$ & BWR & 59 & Shut down & 1966 & Northern States Power (NSP) \\
\hline Peach Bottom-1 & HTGR & 40 & Shut down & 1967 & PEC \\
\hline Peach Bottom-2 & BWR & 1110 & Operating & 1974 & Exelon Nuclear Co \\
\hline Peach Bottom-3 & BWR & 1110 & Operating & 1974 & Exelon Nuclear Co \\
\hline Perry-1 & BWR & 1265 & Operating & 1987 & First Energy \\
\hline Perry-2 & BWR & 1205 & Construction suspended & & First Energy \\
\hline Pilgrim-1 & BWR & 670 & Operating & 1972 & Entergy Nuclear \\
\hline Piqua & OMR & 11 & Shut down & 1963 & US Department of Energy (DOE) \\
\hline Point Beach-1 & PWR & 485 & Operating & 1970 & Wisconsin Electric Power Co \\
\hline Point Beach-2 & PWR & 485 & Operating & 1972 & Wisconsin Electric Power Co \\
\hline Prairie Island-1 & PWR & 530 & Operating & 1973 & Xcel Energy \\
\hline Prairie Island-2 & PWR & 530 & Operating & 1974 & Xcel Energy \\
\hline Quad Cities-1 & BWR & 789 & Operating & 1973 & Exelon Nuclear Co \\
\hline Quad Cities-2 & BWR & 789 & Operating & 1973 & Exelon Nuclear Co \\
\hline R E Ginna & PWR & 495 & Operating & 1970 & Constellation Energy \\
\hline Rancho Seco & PWR & 913 & Shut down & 1975 & $\begin{array}{l}\text { Sacramento Municipal Utility District } \\
\text { (SMUD) }\end{array}$ \\
\hline River Bend-1 & BWR & 936 & Operating & 1986 & Entergy Nuclear \\
\hline Salem-1 & PWR & 1106 & Operating & 1977 & $\begin{array}{l}\text { Public Service Electric and Gas Co } \\
\text { (PSEG) }\end{array}$ \\
\hline Salem-2 & PWR & 1106 & Operating & 1981 & $\begin{array}{l}\text { Public Service Electric and Gas Co } \\
\text { (PSEG) }\end{array}$ \\
\hline $\begin{array}{l}\text { San Onofre-1 } \\
\text { (SONGS-1) }\end{array}$ & PWR & 436 & Shut down & 1968 & $\begin{array}{l}\text { Southern Calfornia Ed.(80\%), } \\
\text { SDGE(20\%) }\end{array}$ \\
\hline San Onofre-2 & PWR & 1070 & Operating & 1983 & Southern California Edison \\
\hline San Onofre-3 & PWR & 1080 & Operating & 1984 & Southern California Edison \\
\hline Santa Susana SRE & Na-graphite & 8 & Shut down & 1957 & DOE leased to SoCalEd \\
\hline Seabrook-1 & PWR & 1162 & Operating & 1990 & Florida Power and Light Co (FPL) \\
\hline Sequoyah-1 & PWR & 1147 & Operating & 1981 & Tennessee Valley Authority (TVA) \\
\hline Sequoyah-2 & PWR & 1142 & Operating & 1982 & Tennessee Valley Authority (TVA) \\
\hline Shearon Harris-1 & PWR & 860 & Operating & 1987 & Progress Energy Corp \\
\hline Shippingport & PWR & 60 & Shut down & 1957 & US Department of Energy (DOE) \\
\hline
\end{tabular}




\section{Inventory and Description of Commercial Reactor Fuels within the United States}

\begin{tabular}{|c|c|c|c|c|c|}
\hline Facility & Process & $\begin{array}{c}\text { Capacity } \\
\text { MW }_{\mathrm{e}} \\
\text { net }\end{array}$ & Current Status & $\begin{array}{l}\text { Start } \\
\text { Year }\end{array}$ & Owner \\
\hline Shoreham & BWR & 809 & Shut down & 1985 & Long Island Power Authority \\
\hline South Texas-1 & PWR & 1268 & Operating & 1988 & STP Nuclear Operating Co \\
\hline South Texas-2 & PWR & 1268 & Operating & 1989 & STP Nuclear Operating Co \\
\hline St. Lucie-1 & PWR & 839 & Operating & 1976 & Florida Power and Light Co (FPL) \\
\hline St. Lucie-2 & PWR & 839 & Operating & 1983 & Florida Power and Light Co (FPL) \\
\hline Surry-1 & PWR & 810 & Operating & 1972 & Dominion Virginia Power \\
\hline Surry-2 & PWR & 815 & Operating & 1973 & Dominion Virginia Power \\
\hline Susquehanna-1 & BWR & 1100 & Operating & 1983 & $\begin{array}{l}\text { Pennsylvania Power and Light Co } \\
\text { (PP\&L) }\end{array}$ \\
\hline Susquehanna-2 & BWR & 1103 & Operating & 1985 & $\begin{array}{l}\text { Pennsylvania Power and Light Co } \\
\text { (PP\&L) }\end{array}$ \\
\hline $\begin{array}{l}\text { Three Mile Island- } \\
1\end{array}$ & PWR & 786 & Operating & 1974 & AmerGen Energy Co \\
\hline $\begin{array}{l}\text { Three Mile Island- } \\
2\end{array}$ & PWR & 905 & Shut down & 1978 & Pen/JCPL/MetEd \\
\hline Trojan & PWR & 1095 & Shut down & 1976 & PortGE/PAcPL/EWEB \\
\hline Turkey Point-3 & PWR & 693 & Operating & 1972 & Florida Power and Light Co (FPL) \\
\hline Turkey Point-4 & PWR & 693 & Operating & 1973 & Florida Power and Light Co (FPL) \\
\hline Vallecitos VBWR & BWR & 5 & Shut down & 1957 & General Electric \\
\hline Vermont Yankee & BWR & 510 & Operating & 1972 & Entergy Nuclear \\
\hline Virgil C Summer-1 & PWR & 885 & Operating & 1984 & South Carolina Electric and Gas Co \\
\hline Vogtle-1 & PWR & 1148 & Operating & 1987 & Southern Nuclear Operating Co \\
\hline Vogtle-2 & PWR & 1149 & Operating & 1989 & Southern Nuclear Operating Co \\
\hline Vogtle-3 & PWR & 1000 & Construction & & Southern Nuclear Operating Co \\
\hline Vogtle-4 & PWR & 1000 & Construction & & Southern Nuclear Operating Co \\
\hline Waterford-3 & PWR & 1075 & Operating & 1985 & Entergy Nuclear \\
\hline Watts Bar-1 & PWR & 1128 & Operating & 1996 & Tennessee Valley Authority (TVA) \\
\hline Watts Bar- 2 & PWR & 1177 & Under construction & & Tennessee Valley Authority (TVA) \\
\hline WNP-1 & PWR & 1259 & Construction suspended & & WPPSS \\
\hline WNP-3 & PWR & 1240 & Construction suspended & & WPPSS \\
\hline WNP-4 & PWR & 1259 & Construction suspended & & WPPSS \\
\hline WNP-5 & PWR & 1240 & Construction suspended & & WPPSS \\
\hline Wolf Creek & PWR & 1135 & Operating & 1985 & KGE/KCPL/KEPC \\
\hline Yankee Rowe & PWR & 167 & Shut down & 1961 & Yankee Atomic Electric Co \\
\hline Yellow Creek-1 & PWR & 1285 & $\begin{array}{l}\text { Suspended } \\
\text { indefinitely/Cancelled }\end{array}$ & & Tennessee Valley Authority (TVA) \\
\hline Yellow Creek-2 & PWR & 1285 & $\begin{array}{l}\text { Suspended } \\
\text { indefinitely/Cancelled }\end{array}$ & & Tennessee Valley Authority (TVA) \\
\hline Zion-1 & PWR & 1040 & Shut down & 1973 & Commonwealth Edison (CommEd) \\
\hline Zion-2 & PWR & 1040 & Shut down & 1974 & Commonwealth Edison (CommEd) \\
\hline
\end{tabular}


Table 2 Total Number of U.S. Reactors by Utility

\begin{tabular}{|lc|lc|}
\hline Alabama Power & 2 & Nebraska Public Power District (NPPD) & 1 \\
\hline Ameren & 1 & Northern States Power (NSP) & 1 \\
\hline AmerGen Energy Co & 3 & Northern Utilities & 2 \\
\hline Argonne National Laboratory (ANL) & 1 & Omaha Public Power District (OPPD) & 1 \\
\hline Arizona Nuclear Power Project (ANPP) & 3 & Pacific Gas and Electric Co (PG\&E) & 3 \\
\hline Atlantic City Electric & 1 & PEC & 1 \\
\hline Commonwealth Edison (CommEd) & 3 & Pen/JCPL/MetEd & 1 \\
\hline Constellation Energy & 5 & Pennsylvania Power and Light Co (PP\&L) & 2 \\
\hline Consumers Energy & 2 & PortGE/PAcPL/EWEB & 1 \\
\hline Consumers Power Corp & 2 & PRDC & 1 \\
\hline Dominion Resources & 1 & Public Service Co of Colorado (PSCC) & 1 \\
\hline Dominion Virginia Power & 6 & Public Service Electric and Gas Co (PSEG) & 3 \\
\hline DPC & 1 & Sacramento Municipal Utility District (SMUD) & 1 \\
\hline Duke Power Co & 15 & South Carolina Electric and Gas Co & 1 \\
\hline Energy Northwest & 1 & Southern Calfornia Ed.(80\%), SDGE(20\%) & 1 \\
\hline Entergy Corp & 1 & Southern California Edison & 2 \\
\hline Entergy Nuclear & 10 & Southern Nuclear Operating Co & 4 \\
\hline Exelon Nuclear Co & 14 & STP Nuclear Operating Co & 2 \\
\hline First Energy & 5 & Tennessee Valley Authority (TVA) & 14 \\
\hline Florida Power and Light Co (FPL) & 5 & TXU Electric Co & 2 \\
\hline FPL Group & 1 & US Department of Energy (DOE) & 5 \\
\hline General Electric & 1 & Wisconsin Electric Power Co & 2 \\
\hline Indiana Michigan Power Co & 2 & WPPSS & 4 \\
\hline KGE/KCPL/KEPC & 1 & Xcel Energy & 3 \\
\hline Long Island Power Authority & 1 & Yankee Atomic Electric Co & 1 \\
\hline Maine Yankee Atomic Power Co & 1 & & \\
\hline
\end{tabular}

Table 3 Total Number of Reactors in U.S. by Type

\begin{tabular}{|l|c|}
\hline Process & $\begin{array}{c}\text { Number of } \\
\text { Reactors }\end{array}$ \\
\hline BWR & 51 \\
\hline FBR & 3 \\
\hline HTGR & 2 \\
\hline Na-graphite & 2 \\
\hline OMR & 1 \\
\hline PHWR & 1 \\
\hline PWR & 94 \\
\hline
\end{tabular}


Table 4 Fuel Assembly Geometry by Assembly Design Type

\begin{tabular}{|l|c|c|}
\hline Design & $\begin{array}{c}\text { Assembly } \\
\text { Length (in) }\end{array}$ & $\begin{array}{c}\text { Assembly } \\
\text { Width (in) }\end{array}$ \\
\hline B\&W-15 & 173.5 & 8.54 \\
\hline BIG-PT & 84.8 & 6.81 \\
\hline CE-14 & 169.6 & 8.11 \\
\hline CE-16 & 190.8 & 8.14 \\
\hline DRES-1 & 135.7 & 4.57 \\
\hline FT.-CAL & 158.5 & 8.12 \\
\hline GE-2 & 173 & 5.61 \\
\hline GE-3 & 173 & 5.61 \\
\hline GE-4 & 177.8 & 5.61 \\
\hline GE-5 & 177.8 & 5.61 \\
\hline GE-6 & 177.8 & 5.61 \\
\hline HAD-NECK & 139.9 & 8.5 \\
\hline HUM-BY & 96 & 4.8 \\
\hline IND-PT1 & 139.1 & 6.27 \\
\hline LACROS & 103.5 & 5.91 \\
\hline PALIS & 148.9 & 8.31 \\
\hline SAN-1 & 139.9 & 7.76 \\
\hline SOU-TX & 201.1 & 8.4 \\
\hline ST-LUC2 & 170.6 & 8.13 \\
\hline SYS-80 & 194.8 & 8.16 \\
\hline WE-14 & 166.3 & 7.76 \\
\hline WE-15 & 166.9 & 8.42 \\
\hline WE-17 & 168.8 & 8.42 \\
\hline YANK-RW & 112.9 & 7.61 \\
\hline & & \\
\hline
\end{tabular}

Table 5 Nominal Compositions of Alloys Used as Nuclear Fuel Cladding

\begin{tabular}{|c|c|c|c|c|c|c|c|c|c|}
\hline Alloy & $\begin{array}{c}\text { Sn } \\
(w t \%)\end{array}$ & $\begin{array}{c}\text { Fe } \\
(w t \%)\end{array}$ & $\begin{array}{c}\mathrm{Cr} \\
(\mathrm{wt} \%)\end{array}$ & $\begin{array}{c}\mathrm{Nb} \\
(\mathrm{wt} \%)\end{array}$ & $\begin{array}{c}\mathrm{Ni} \\
(\mathrm{wt} \%)\end{array}$ & $\begin{array}{c}O \\
(w t \%)\end{array}$ & $\begin{array}{c}\mathrm{C} \\
(\mathrm{wt} \%)\end{array}$ & $\begin{array}{c}\mathrm{Si} \\
(\mathrm{wt} \%)\end{array}$ & $\begin{array}{c}\mathrm{Zr} \\
(\mathrm{wt} \%)\end{array}$ \\
\hline Zr- 2 (BWR) & 1.5 & 0.12 & 0.1 & & 0.05 & 0.13 & & & Balance \\
\hline Zr- 2 (BWR) Improved & 1.3 & 0.17 & 0.1 & & 0.06 & 0.13 & & & Balance \\
\hline Zr -4 (PWR) High Tin & 1.55 & 0.22 & 0.12 & & & 0.12 & 0.015 & 0.01 & Balance \\
\hline Zr -4 (PWR) Improved & 1.3 & 0.22 & 0.12 & & & 0.12 & 0.012 & 0.01 & Balance \\
\hline M5 $®$ & & 0.04 & & 1 & & 0.14 & & & Balance \\
\hline ZIRLOTM $^{\mathrm{TM}}$ & 1 & 0.1 & & 1 & & 0.12 & & & Balance \\
\hline Optimized ZIRLO TM & 0.7 & 0.1 & & 1 & & 0.12 & & & Balance \\
\hline $\begin{array}{l}\text { Zircaloy } 2 \text { Specification } \\
\text { ASTM B811 }\end{array}$ & $\begin{array}{l}1.2- \\
1.7\end{array}$ & $\begin{array}{c}0.07- \\
0.20\end{array}$ & $\begin{array}{c}0.05- \\
0.15\end{array}$ & & $\begin{array}{c}0.03- \\
0.08\end{array}$ & $\begin{array}{l}0.09- \\
0.16\end{array}$ & $\begin{array}{c}0.027 \\
\max \end{array}$ & $\begin{array}{c}0.012 \\
\max \end{array}$ & Balance \\
\hline $\begin{array}{l}\text { Ziracloy } 4 \text { Specification } \\
\text { ASTM B811 }\end{array}$ & $\begin{array}{c}1.2- \\
1.7\end{array}$ & $\begin{array}{c}0.18- \\
0.24\end{array}$ & $\begin{array}{c}0.07- \\
0.13 \\
\end{array}$ & & & $\begin{array}{l}0.09- \\
0.16\end{array}$ & $\begin{array}{c}0.027 \\
\max \end{array}$ & $\begin{array}{c}0.012 \\
\max \end{array}$ & Balance \\
\hline
\end{tabular}


Table 6 Reactor Storage Pools, Independent Spent Fuel Storage Installations, Federal, and Other Sites

\begin{tabular}{|c|c|c|c|c|c|c|c|c|c|c|c|}
\hline \multicolumn{4}{|c|}{ Facility } & \multirow{2}{*}{$\begin{array}{c}\text { Assemblies } \\
1,517\end{array}$} & \multirow{2}{*}{$\begin{array}{l}\text { MT } \\
666.7\end{array}$} & \multicolumn{4}{|c|}{ Facility } & Assemblies & \multirow{2}{*}{$\begin{array}{l}\text { MT } \\
964.5\end{array}$} \\
\hline \multirow[t]{2}{*}{1} & \multirow[t]{2}{*}{ Arkansas Nuclear One } & \multirow[t]{2}{*}{ AK } & $\mathrm{P}$ & & & 46 & Shearon Harris Nuc Pwr Plnt & $\mathrm{NC}$ & $P$ & 3,814 & \\
\hline & & & I & 552 & 241.4 & 47 & Cooper Nuclear Station & $\mathrm{NE}$ & $\mathrm{P}$ & 1,537 & 278.6 \\
\hline 2 & Browns Ferry Nuclear Plant & $\mathrm{AL}$ & $\mathrm{P}$ & 6,696 & 1230.2 & 48 & Fort Calhoun Station & $\mathrm{NE}$ & $\mathrm{P}$ & 839 & 305.0 \\
\hline 3 & J M Farley Nuclear Plant & $\mathrm{AL}$ & $\mathrm{P}$ & 2,011 & 903.8 & 49 & Seabrook Nuclear Station & $\mathrm{NH}$ & $\mathrm{P}$ & 624 & 287.2 \\
\hline 4 & Palo Verde Nuc Gen Station & $\mathrm{AZ}$ & $\mathrm{P}$ & 2,747 & 1157.8 & 50 & Hope Creek Gen Station & NJ & $\mathrm{P}$ & 2,376 & 431.5 \\
\hline 5 & Diablo Canyon Power Plant & CA & $\mathrm{P}$ & 1,736 & 760.9 & \multirow[t]{2}{*}{51} & \multirow[t]{2}{*}{ Oyster Creek Generating Sta } & \multirow[t]{2}{*}{ NJ } & $\mathrm{P}$ & 2,556 & 455.9 \\
\hline 6 & GE Vallecitos Nuc Center & CA & I & fragments & 0.2 & & & & I & 244 & 47.6 \\
\hline 7 & Humboldt Bay Power Plant & CA & $\mathrm{P}$ & 390 & 28.9 & 52 & Salem Nuc Generating Sta & NJ & $\mathrm{P}$ & 1,804 & 832.7 \\
\hline 8 & Rancho Seco Nuc Gen Station & CA & I & 493 & 228.4 & 53 & Sandia National Laboratory & NM & $\mathrm{F}$ & 503 & 0.3 \\
\hline 9 & San Onofre Nuc Gen Station & CA & $\mathrm{P}$ & 2,490 & 1013.3 & 54 & Brookhaven National Lab & NY & F & 40 & $<0.1$ \\
\hline 10 & Fort St. Vrain Power Station & $\mathrm{CO}$ & $\mathrm{F}$ & 1,464 & 14.7 & 55 & JA Fitzpatrick Nuc Pwr Plant & NY & $\mathrm{P}$ & 2,460 & 446.5 \\
\hline 11 & Connecticut Yankee Atom Pwr & CT & $\mathrm{P}$ & 1,019 & 412.3 & & & & I & 204 & 37.2 \\
\hline 12 & Millstone Nuc Power Station & CT & $\mathrm{P}$ & 4,558 & 1227.9 & 56 & Indian Point Energy Center & NY & $\mathrm{P}$ & 2,073 & 903.6 \\
\hline 13 & Crystal River Nuc Power Plant & FL & $\mathrm{P}$ & 824 & 382.3 & 57 & Nine Mile Point Nuclear Station & NY & $\mathrm{P}$ & 4,456 & 801.6 \\
\hline 14 & St. Lucie Nuc Power Plant & FL & $\mathrm{P}$ & 2,278 & 870.7 & 58 & R E Ginna Nuclear Power Plant & NY & $\mathrm{P}$ & 967 & 357.4 \\
\hline 15 & Turkey Point Station & FL & $\mathrm{P}$ & 1,862 & 851.7 & 59 & Davis-Besse Nuclear Pwr Sta & $\mathrm{OH}$ & $\mathrm{P}$ & 749 & 351.3 \\
\hline 16 & AW Vogtle Electric Gen Plant & GA & $\mathrm{P}$ & 1,639 & 720.8 & & & & I & 72 & 33.9 \\
\hline \multirow[t]{2}{*}{17} & \multirow[t]{2}{*}{ EL Hatch Nuclear Plant } & \multirow[t]{2}{*}{ GA } & $\mathrm{P}$ & 5,019 & 909.3 & 60 & Perry Nuclear Power Plant & $\mathrm{OH}$ & $\mathrm{P}$ & 2,088 & 378.4 \\
\hline & & & I & 816 & 151.2 & 61 & Trojan Nuclear Power Plant & OR & $\mathrm{P}$ & 780 & 358.9 \\
\hline 18 & D Arnold Energy Center & IA & $\mathrm{P}$ & 1,912 & 347.9 & 62 & Beaver Valley Power Station & PA & $\mathrm{P}$ & 1,456 & 672.9 \\
\hline 19 & Idaho National Eng \& Env Lab & ID & $\mathrm{F}$ & 93,522 & 299.3 & 63 & Limerick Generating Station & PA & $\mathrm{P}$ & 4,601 & 824.0 \\
\hline 20 & Argonne National Lab East & IL & $\mathrm{F}$ & 78 & 0.1 & 64 & Peach Bottom Atm Pwr Sta & $\mathrm{PA}$ & $\mathrm{P}$ & $5,905.0$ & $1,062.7$ \\
\hline 21 & Braidwood Generating Sta & IL & $\mathrm{P}$ & 1,485 & 628.7 & & & & I & 1,020 & 190.3 \\
\hline 22 & Byron Generating Station & IL & $\mathrm{P}$ & 1,786 & 756.4 & 65 & Susquehanna Steam Elec Sta & PA & $\mathrm{P}$ & 4,240 & 738.4 \\
\hline 23 & Clinton Power Station & IL & $\mathrm{P}$ & 1,580 & 288.8 & & & & I & 1,300 & 238.5 \\
\hline 24 & Dresden Generating Station & IL & $\mathrm{P}$ & 5,698 & $1,009.2$ & 66 & Three Mile Island Nuc Station & PA & $\mathrm{P}$ & 898 & 416.1 \\
\hline & & & I & 1,155 & 146.9 & 67 & Catawba Nuclear Station & SC & $\mathrm{P}$ & 1,780 & 782.4 \\
\hline 25 & GE Morris Operation & IL & I & 3,217 & 674.3 & 68 & HB Robinson Steam Elec & SC & $\mathrm{P}$ & 344 & 147.9 \\
\hline 26 & LaSalle County Gen Sta & IL & $\mathrm{P}$ & 4,106 & 744.6 & & & & I & 56 & 24.1 \\
\hline 27 & Quad Cities Gen Station & IL & $\mathrm{P}$ & 6,116 & 1106.5 & 69 & Oconee Nuclear Station & SC & $\mathrm{P}$ & 1,419 & 665.8 \\
\hline 28 & Zion Generating Station & IL & $\mathrm{P}$ & 2,226 & 1019.4 & & & & I & 1,726 & 800.4 \\
\hline 29 & Wolf Creek Gen Station & KS & $\mathrm{P}$ & 925 & 427.3 & 70 & Savannah River Defense Site & SC & $\mathrm{F}$ & 9,657 & 28.9 \\
\hline 30 & River Bend Station & LA & $\mathrm{P}$ & 2,148 & 383.9 & 71 & VC Summer Nuclear Station & SC & $\mathrm{P}$ & 812 & 353.9 \\
\hline 31 & Waterford Gen Sta & LA & $\mathrm{P}$ & 960 & 396.4 & 72 & Sequoyah Nuclear Power Plant & $\mathrm{TN}$ & $\mathrm{P}$ & 1,699 & 782.6 \\
\hline 32 & Pilgrim Nuclear Station & MA & $\mathrm{P}$ & 2,274 & 413.9 & 73 & Watts Bar Nuclear Plant & $\mathrm{TN}$ & $\mathrm{P}$ & 297 & 136.6 \\
\hline 33 & Yankee Rowe Nuc Power Sta & MA & I & 533 & 127.1 & 74 & Comanche Peak Steam Elec Sta & $\mathrm{TX}$ & $\mathrm{P}$ & 1,273 & 540.7 \\
\hline 34 & Calvert Cliffs Nuc Pwr Plt & MD & $\mathrm{P}$ & 1,348 & 518.0 & 75 & South Texas Project & $\mathrm{TX}$ & $\mathrm{P}$ & 1,254 & 677.8 \\
\hline & & & I & 960 & 368.1 & 76 & North Anna Power Station & VA & $\mathrm{P}$ & 1,410 & 652.7 \\
\hline 35 & Maine Yankee Atomic Pwr Plt & $\mathrm{ME}$ & I & 1,434 & 542.3 & & & & I & 480 & 220.8 \\
\hline 36 & Big Rock Point Nuc Plt & MI & I & 441 & 57.9 & 77 & Surry Power Station & VA & $\mathrm{P}$ & 794 & 365.4 \\
\hline 37 & D C Cook Nuclear Plant & MI & $\mathrm{P}$ & 2,198 & 969.0 & & & & I & 1,150 & 524.2 \\
\hline 38 & Enrico Fermi Atomic Pwr Plt & MI & $\mathrm{P}$ & 1,708 & 304.6 & 78 & Vermont Yankee Gen Station & VT & $\mathrm{P}$ & 2,671 & 488.4 \\
\hline 39 & Palisades Nuclear Pwr Sta & MI & $\mathrm{P}$ & 649 & 260.7 & 79 & Columbia Generating Station & WA & $\mathrm{P}$ & 1,904 & 333.7 \\
\hline & & & I & 432 & 172.4 & & & & I & 340 & 61.0 \\
\hline 40 & Monticello Nuclear Gen Plant & MN & $\mathrm{P}$ & 1,342 & 236.1 & 80 & Hanford Defense Site & WA & $\mathrm{F}$ & 110,140 & 2128.9 \\
\hline 41 & Prairie Isl. Nuc Gen Plt & MN & $\mathrm{P}$ & 1,135 & 410.3 & 81 & Kewaunee Nuclear Power Plant & WI & $\mathrm{P}$ & 904 & 347.6 \\
\hline & & & I & 680 & 262.3 & 82 & La Crosse Nuclear Gen Station & WI & $\mathrm{P}$ & 333 & 38.0 \\
\hline 42 & Callaway Nuclear Plant & MO & $\mathrm{P}$ & 1,118 & 479.0 & 83 & Point Beach Nuclear Plant & WI & $\mathrm{P}$ & 1,353 & 507.4 \\
\hline 43 & Grand Gulf Nuclear Station & MS & $\mathrm{P}$ & 3,160 & 560.2 & & & & I & 360 & 144.1 \\
\hline 44 & Brunswick Stm Elec Plt & NC & $\mathrm{P}$ & 2,227 & 477.4 & Other & : University \& Industry & & $\mathrm{F}$ & 4,834 & 1.7 \\
\hline 45 & W B McGuire Nuc Sta & NC & $\mathrm{P}$ & 2,232 & 1001.1 & & & & & & \\
\hline & & & $\mathrm{I}$ & 160 & 68.6 & & Combined Total & & & 383,653 & $49,401.2$ \\
\hline & Reactor Pool & & $\mathrm{P}$ & 145,589 & $41,564.1$ & & & & & & \\
\hline & ISFSI & & I & 17,826 & $5,363.2$ & & & & & & \\
\hline & Federal and Other & & $\mathrm{F}$ & 220,238 & $2,473.9$ & & & & & metric ton ( & ,000 kg) \\
\hline
\end{tabular}


Table 7 Range of Burnup for Used Nuclear Fuel by Reactor

\begin{tabular}{|c|c|c|c|}
\hline \multirow[b]{2}{*}{ Reactor Name } & \multicolumn{2}{|c|}{ Burnup (MWd/MTIHM) } & \multirow{2}{*}{$\begin{array}{c}\text { Average } \\
\text { Enrichment (\%) }\end{array}$} \\
\hline & Minimum & Maximum & \\
\hline Arkansas Nuclear One & 14,338 & 71,300 & 3.56 \\
\hline Arkansas Nuclear Two & 1 & 69,490 & 3.98 \\
\hline Beaver Valley-1 & 16,550 & 67,172 & 3.82 \\
\hline Beaver Valley-2 & 15,292 & 66,697 & 4.25 \\
\hline Big Rock-1 & 1,642 & 34,001 & 3.44 \\
\hline Braidwood-1 & 15,774 & 64,024 & 4.16 \\
\hline Braidwood-2 & 15,614 & 63,374 & 4.18 \\
\hline Browns Ferry-1 & 5,750 & 58,158 & 3.23 \\
\hline Browns Ferry-2 & 8,580 & 62,292 & 3.17 \\
\hline Browns Ferry-3 & 11,347 & 63,320 & 3.33 \\
\hline Brunswick-1 & 4,365 & 65,550 & 3.23 \\
\hline Brunswick-2 & 2,426 & 60,377 & 3.22 \\
\hline Byron-1 & 15,472 & 62,796 & 3.97 \\
\hline Byron-2 & 15,770 & 64,007 & 4.13 \\
\hline Calloway-1 & 15,304 & 67,494 & 4.20 \\
\hline Calvert Cliffs-1 & 12,219 & 69,276 & 3.70 \\
\hline Calvert Cliffs-2 & 16,840 & 68,349 & 3.78 \\
\hline Catawba-1 & 12,032 & 69,088 & 3.85 \\
\hline Catawba-2 & 12,396 & 68,707 & 3.91 \\
\hline Clinton-1 & 2,813 & 65,550 & 3.02 \\
\hline Comanche Peak-1 & 12,000 & 66,320 & 4.47 \\
\hline Comanche Peak-2 & 14,000 & 65,875 & 4.59 \\
\hline Cook-1 & 5,845 & 64,394 & 3.68 \\
\hline Cook-2 & 14,640 & 68,039 & 4.14 \\
\hline Cooper Station & 7,507 & 65,550 & 3.09 \\
\hline Crystal River-3 & 8,652 & 68,183 & 3.75 \\
\hline Davis Besse-1 & 15,806 & 64,153 & 4.16 \\
\hline Diablo Canyon-1 & 15,463 & 62,761 & 4.44 \\
\hline Diablo Canyon-2 & 15,559 & 67,683 & 4.37 \\
\hline Dresden-1 & 3,389 & 29,000 & 2.16 \\
\hline Dresden-2 & 8,870 & 64,802 & 3.01 \\
\hline Dresden-3 & 4,278 & 65,550 & 3.02 \\
\hline Duane Arnold & 3,709 & 58,884 & 3.68 \\
\hline Enrico Fermi-1 & 2,372 & 65,550 & 3.50 \\
\hline Farley-1 & 7,409 & 69,455 & 4.02 \\
\hline Farley-2 & 14,103 & 68,072 & 4.17 \\
\hline Fitzpatrick & 7,262 & 65,550 & 3.81 \\
\hline Fort Calhoun & 8,039 & 69,116 & 3.89 \\
\hline GE Morris & 177 & 4,764 & 1.90 \\
\hline Ginna & 5,856 & 64,149 & 3.98 \\
\hline
\end{tabular}




\begin{tabular}{|c|c|c|c|}
\hline \multirow[b]{2}{*}{ Reactor Name } & \multicolumn{2}{|c|}{ Burnup (MWd/MTIHM) } & \multirow{2}{*}{$\begin{array}{c}\text { Average } \\
\text { Enrichment (\%) }\end{array}$} \\
\hline & Minimum & Maximum & \\
\hline Grand Gulf-1 & 3,353 & 65,550 & 3.34 \\
\hline Haddam Neck & 8,193 & 42,956 & 3.92 \\
\hline Harris-1 & 15,999 & 64,938 & 4.12 \\
\hline Hatch-1 & 5,508 & 65,550 & 3.04 \\
\hline Hatch-2 & 1,830 & 65,550 & 2.92 \\
\hline Hope Creek & 1,901 & 65,550 & 2.84 \\
\hline Humboldt Bay & 1,307 & 22,617 & 2.37 \\
\hline Indian Point-1 & 3,713 & 27,048 & 4.00 \\
\hline Indian Point-2 & 12,034 & 60,368 & 4.24 \\
\hline Indian Point-3 & 15,900 & 66,608 & 4.34 \\
\hline Kewaunee & 15,499 & 62,907 & 4.16 \\
\hline Lacrosse & 4,683 & 20,988 & 3.77 \\
\hline LaSalle-1 & 2,639 & 65,550 & 3.08 \\
\hline LaSalle-2 & 2,624 & 65,550 & 2.87 \\
\hline Limerick-1 & 2,379 & 65,550 & 2.82 \\
\hline Limerick-2 & 0 & 65,550 & 3.49 \\
\hline Maine Yankee & 2,768 & 49,241 & 2.97 \\
\hline McGuire-1 & 14,500 & 68,589 & 3.82 \\
\hline McGuire-2 & 13,632 & 70,356 & 3.85 \\
\hline Millstone-1 & 4,697 & 36,760 & 2.73 \\
\hline Millstone-2 & 15,155 & 71,300 & 3.59 \\
\hline Millstone-3 & 16,132 & 65,479 & 4.22 \\
\hline Monticello & 7,388 & 65,170 & 3.26 \\
\hline Nine Mile Point-1 & 5,244 & 51,284 & 3.06 \\
\hline Nine Mile Point-2 & 2,805 & 65,550 & 3.74 \\
\hline North Anna-1 & 12,166 & 66,914 & 4.15 \\
\hline North Anna-2 & 12,915 & 66,864 & 4.25 \\
\hline Oconee-1 & 4,286 & 71,300 & 3.37 \\
\hline Oconee-2 & 12,524 & 71,300 & 3.40 \\
\hline Oconee-3 & 13,960 & 67,927 & 3.39 \\
\hline Oyster Creek-1 & 4,493 & 65,493 & 3.10 \\
\hline Palisades & 5,139 & 68,523 & 3.42 \\
\hline Palo Verde-1 & 16,049 & 67,402 & 4.11 \\
\hline Palo Verde-2 & 16,572 & 67,754 & 4.10 \\
\hline Palo Verde-3 & 14,216 & 67,479 & 4.15 \\
\hline Peack Bottom-2 & 3,886 & 65,550 & 3.15 \\
\hline Peack Bottom-3 & 1,371 & 65,550 & 3.23 \\
\hline Perry-1 & 5,000 & 65,550 & 4.00 \\
\hline Pilgrim-1 & 2,625 & 65,550 & 3.62 \\
\hline Point Beach-1 & 10,864 & 68,885 & 3.82 \\
\hline Point Beach-2 & 12,412 & 68,421 & 3.86 \\
\hline Prairie Island-1 & 15,893 & 69,452 & 4.17 \\
\hline Prairie Island-2 & 16,070 & 65,226 & 4.19 \\
\hline
\end{tabular}




\begin{tabular}{|l|c|c|c|}
\hline \multirow{2}{*}{ Reactor Name } & \multicolumn{2}{|c|}{ Burnup (MWd/MTIHM) } & \multirow{2}{*}{$\begin{array}{c}\text { Average } \\
\text { Enrichment (\%) }\end{array}$} \\
\cline { 2 - 3 } & Minimum & Maximum & \\
\hline Quad Cities-1 & 7,573 & 63,279 & 2.92 \\
\hline Quad Cities-2 & 7,140 & 65,550 & 2.96 \\
\hline Rancho Seco-1 & 10,000 & 38,054 & 2.81 \\
\hline Robinson-2 & 13,561 & 68,993 & 3.68 \\
\hline River Bend-1 & 1,969 & 65,550 & 3.83 \\
\hline Salem-1 & 8,910 & 69,039 & 4.05 \\
\hline Salem-2 & 16,983 & 68,932 & 4.15 \\
\hline San Onofre-1 & 6,905 & 38,935 & 3.86 \\
\hline San Onofre-2 & 11,053 & 67,525 & 4.08 \\
\hline San Onofre-3 & 14,290 & 67,676 & 4.08 \\
\hline Seabrook-1 & 12,781 & 68,142 & 4.31 \\
\hline Sequoyah-1 & 14,723 & 68,213 & 4.31 \\
\hline Sequoyah-2 & 14,683 & 66,582 & 4.33 \\
\hline South Texas-1 & 10,825 & 70,896 & 3.83 \\
\hline South Texas-2 & 11,402 & 67,483 & 4.02 \\
\hline Saint Lucie-1 & 2,000 & 70,807 & 3.71 \\
\hline Saint Lucie-2 & 9,908 & 71,300 & 3.97 \\
\hline Summer-1 & 14,037 & 65,698 & 4.47 \\
\hline Surry-1 & 14,963 & 68,428 & 3.85 \\
\hline Surry-2 & 11,008 & 71,300 & 3.86 \\
\hline Susquehanna-1 & 3,000 & 65,550 & 3.64 \\
\hline Susquehanna-2 & 3,000 & 65,550 & 3.59 \\
\hline Trojan & 5,000 & 42,033 & 3.07 \\
\hline Turkey Point-3 & 12,665 & 67,956 & 3.82 \\
\hline Turkey Point-34 & 8,381 & 68,532 & 3.80 \\
\hline Vogtle-1 & 15,301 & 67,576 & 4.42 \\
\hline Vogtle-2 & 16,815 & 68,248 & 4.47 \\
\hline Vermont Yankee-1 & 13,536 & 65,666 & 3.67 \\
\hline Washington Nuclear-2 & 1,710 & 64,669 & 3.64 \\
\hline Waterford-3 & 11,725 & 65,091 & 4.16 \\
\hline Watts Bar-1 & 11,817 & 67,459 & 4.57 \\
\hline Wolf Creek-1 & 16,515 & 67,033 & 3.95 \\
\hline Yankee Rowe-1 & & 35,221 & 3.95 \\
\hline Zion-1 & 54,964 & 3.17 \\
\hline Zion-2 & & 48,319 & 3.25 \\
\hline 3 Mile Island-1 & & \\
\hline & & & 3.67 \\
\hline
\end{tabular}


Table 8 Pool types and Capacity by Utility

\begin{tabular}{|c|c|c|c|c|}
\hline Utility & Pool Name & Capacity & $\begin{array}{l}\text { Fuel } \\
\text { Core } \\
\text { Reserve }\end{array}$ & $\begin{array}{l}\text { Fuel } \\
\text { Type } \\
\end{array}$ \\
\hline \multirow{4}{*}{$\begin{array}{l}\text { Southern Nuclear } \\
\text { Operating Co }\end{array}$} & FARLEY 1 & 1407 & 157 & PWR \\
\hline & FARLEY 2 & 1407 & 157 & PWR \\
\hline & HATCH 1 & 6026 & 560 & BWR \\
\hline & VOGTLE 1 & 3574 & 193 & PWR \\
\hline \multirow{3}{*}{$\begin{array}{l}\text { Arizona Nuclear Power } \\
\text { Project (ANPP) }\end{array}$} & PALO VERDE 3 & 1329 & 241 & PWR \\
\hline & PALO VERDE 1 & 1329 & 241 & PWR \\
\hline & PALO VERDE 2 & 1329 & 241 & PWR \\
\hline \multirow{11}{*}{ Entergy Nuclear } & INDIAN PT 3 & 1345 & 193 & PWR \\
\hline & ARK NUCLEAR 1 & 941 & 177 & PWR \\
\hline & ARK NUCLEAR 2 & 937 & 177 & PWR \\
\hline & GRAND GULF 1 & 4331 & 800 & BWR \\
\hline & PILGRIM 1 & 3404 & 580 & BWR \\
\hline & VT YANKEE 1 & 3335 & 368 & BWR \\
\hline & WATERFORD 3 & 1880 & 217 & PWR \\
\hline & RVR BEND 1 & 3172 & 624 & BWR \\
\hline & INDIAN PT 1 & 756 & 0 & PWR \\
\hline & INDIAN PT 2 & 1374 & 193 & PWR \\
\hline & FITZPATRICK & 3108 & 560 & BWR \\
\hline \multirow{3}{*}{ Constellation Energy } & CALVERT CLF 1 & 1830 & 217 & PWR \\
\hline & NINE MILE PT1 & 3910 & 532 & BWR \\
\hline & NINE MILE PT2 & 4000 & 764 & BWR \\
\hline \multirow{15}{*}{ Duke Power Co } & CATAWBA 1 & 1419 & 193 & PWR \\
\hline & OCONEE 1 & 1550 & 177 & PWR \\
\hline & MCGUIRE 2 & 1229 & 193 & PWR \\
\hline & MCGUIRE 1 & 1236 & 193 & PWR \\
\hline & OCONEE 3 & 887 & 177 & PWR \\
\hline & $\begin{array}{l}\text { CATAWBA } 2 \\
\end{array}$ & 1418 & 193 & PWR \\
\hline & HARRIS - BWR & 9999 & 0 & BWR \\
\hline & HARRIS 1 & 5228 & 157 & PWR \\
\hline & ROBINSON 2 & 1292 & 157 & PWR \\
\hline & BRUNSWICK 2 & 3508 & 560 & BWR \\
\hline & BRUNSWICK 1 & 3258 & 560 & BWR \\
\hline & CRYSTAL RVR 3 & 1474 & 177 & PWR \\
\hline & BRUNS 1 - PWR & 160 & 0 & PWR \\
\hline & BRUNS 2 - PWR & 144 & 0 & PWR \\
\hline & HARRIS- ROBIN & 9999 & 0 & PWR \\
\hline \multirow{4}{*}{ First Energy } & BEAVER VALLEY 1 & 1627 & 157 & PWR \\
\hline & BEAVER VALLEY 2 & 1088 & 157 & PWR \\
\hline & DAVIS-BESSE 1 & 1624 & 177 & PWR \\
\hline & PERRY 1 & 4020 & 748 & BWR \\
\hline
\end{tabular}




\begin{tabular}{|c|c|c|c|c|}
\hline Utility & Pool Name & Capacity & $\begin{array}{l}\text { Fuel } \\
\text { Core } \\
\text { Reserve } \\
\end{array}$ & $\begin{array}{l}\text { Fuel } \\
\text { Type }\end{array}$ \\
\hline \multirow{16}{*}{ Exelon Nuclear Co } & QUAD CITIES 1 & 7523 & 724 & BWR \\
\hline & PEACHBOTTOM 3 & 3816 & 764 & BWR \\
\hline & РЕАСНВОТTOM 2 & 3807 & 764 & BWR \\
\hline & BRAIDWOOD 1 & 2972 & 193 & PWR \\
\hline & LASALLE 1 & 7669 & 764 & BWR \\
\hline & DRESDEN 3 & 3534 & 724 & BWR \\
\hline & ZION 1 & 3012 & 0 & PWR \\
\hline & 3 MILE ISL 1 & 1989 & 177 & PWR \\
\hline & BYRON 1 & 2955 & 193 & PWR \\
\hline & DRES 1 IN 2 & 102 & 0 & BWR \\
\hline & DRES 1 IN 3 & 104 & 0 & BWR \\
\hline & $\begin{array}{ll}\text { CLINTON } \quad 1 \\
\end{array}$ & 4060 & 624 & BWR \\
\hline & OYSTER CRK 1 & 2997 & 560 & BWR \\
\hline & DRESDEN 1 & 889 & 0 & BWR \\
\hline & DRESDEN 2 & 3536 & 724 & BWR \\
\hline & LIMERICK 1 & 7373 & 764 & BWR \\
\hline \multirow{2}{*}{ Consumers Energy } & BIG ROCK 1 & 441 & 0 & PWR \\
\hline & PALISADES & 773 & 204 & PWR \\
\hline DPC & LACROSSE & 440 & 0 & BWR \\
\hline Detroit Edison Co & ENRICO FERMI2 & 3588 & 764 & BWR \\
\hline \multirow{5}{*}{$\begin{array}{l}\text { Florida Power and Light } \\
\text { Co (FPL) }\end{array}$} & SEABROOK 1 & 1227 & 193 & PWR \\
\hline & ST LUCIE 2 & 1585 & 217 & PWR \\
\hline & TURKEY PT 4 & 1535 & 157 & PWR \\
\hline & ST LUCIE 1 & 1849 & 217 & PWR \\
\hline & TURKEY PT 3 & 1535 & 157 & PWR \\
\hline \multirow{2}{*}{$\begin{array}{l}\text { STP Nuclear Operating } \\
\text { Co }\end{array}$} & SOUTH TEXAS 1 & 1969 & 193 & STP \\
\hline & SOUTH TEXAS 2 & 1969 & 193 & STP \\
\hline FPL Group & DUANE ARNOLD & 2411 & 368 & BWR \\
\hline KGE/KCPL/KEPC & WOLF CREEK 1 & 2642 & 193 & PWR \\
\hline $\begin{array}{l}\text { Maine Yankee Atomic } \\
\text { Power Co }\end{array}$ & MAINE YANKEE & 2019 & 0 & PWR \\
\hline \multirow{2}{*}{$\begin{array}{l}\text { Nebraska Public Power } \\
\text { District (NPPD) }\end{array}$} & COOPER STN & 3705 & 548 & BWR \\
\hline & Cooper at MORRIS & 9999 & 0 & BWR \\
\hline \multirow{2}{*}{ Northern Utilities } & HADDAM NECK & 1172 & 0 & PWR \\
\hline & HadNck at MORRIS & 9999 & 0 & PWR \\
\hline \multirow{5}{*}{$\begin{array}{l}\text { Dominion Virginia } \\
\text { Power }\end{array}$} & MILLSTONE 1 & 2884 & 0 & BWR \\
\hline & MILLSTONE 2 & 1339 & 217 & PWR \\
\hline & MILLSTONE 3 & 1689 & 193 & PWR \\
\hline & NORTH ANNA 1 & 1737 & 157 & PWR \\
\hline & SURRY 1 & 1042 & 157 & PWR \\
\hline \multirow{2}{*}{ Xcel Energy } & PRAIRIE ISL 1 & 1386 & 121 & PWR \\
\hline & MONTICELLO & 3310 & 484 & BWR \\
\hline
\end{tabular}




\begin{tabular}{|c|c|c|c|c|}
\hline Utility & Pool Name & Capacity & $\begin{array}{l}\text { Fuel } \\
\text { Core } \\
\text { Reserve }\end{array}$ & $\begin{array}{l}\text { Fuel } \\
\text { Type }\end{array}$ \\
\hline & Montic at MORRIS & 9999 & 0 & BWR \\
\hline $\begin{array}{l}\text { Omaha Public Power } \\
\text { District (OPPD) }\end{array}$ & FORT CALHOUN & 1083 & 133 & PWR \\
\hline \multirow{3}{*}{$\begin{array}{l}\text { Pacific Gas and Electric } \\
\text { Co (PG\&E) }\end{array}$} & HUMBOLDT BAY & 487 & 0 & BWR \\
\hline & DIABLO CANYON 1 & 1324 & 193 & PWR \\
\hline & DIABLO CANYON 2 & 1324 & 193 & PWR \\
\hline $\begin{array}{l}\text { Pennsylvania Power and } \\
\text { Light Co (PP\&L) }\end{array}$ & SUSQUEHANNA 1 & 5680 & 764 & BWR \\
\hline PortGE/PAcPL/EWEB & TROJAN & 1408 & 0 & PWR \\
\hline \multirow{30}{*}{ Department of Energy } & ISF1-HLW & No Pool & 0 & \\
\hline & MGR1-Bare B & No Pool & 0 & \\
\hline & ISF1-DOE & No Pool & 0 & \\
\hline & HANFORD-HLW & No Pool & 0 & HLWL \\
\hline & INEEL-HLW & No Pool & 0 & HLW \\
\hline & HANFORD WA P & No Pool & 0 & PWR \\
\hline & HANFORD WA B & No Pool & 0 & BWR \\
\hline & SAVAN RIV & No Pool & 0 & \\
\hline & ISF1-Bare P & No Pool & 0 & \\
\hline & SRS-DSNF-15' & No Pool & 0 & DSNFL \\
\hline & ISF1-Bare B & No Pool & 0 & \\
\hline & INEEL-DSNF-10' & No Pool & 0 & DSNF \\
\hline & INEEL-DSNF24-15' & No Pool & 0 & DSNFL \\
\hline & SRS-DSNF24-10' & No Pool & 0 & DSNF \\
\hline & SRS-PU-HLW & No Pool & 0 & HLWL \\
\hline & SRS-HLW & No Pool & 0 & HLW \\
\hline & MGR1-Bare P-Store & No Pool & 0 & \\
\hline & INEEL-DSNF-15' & No Pool & 0 & DSNFL \\
\hline & MGR1-Bare B-Store & No Pool & 0 & \\
\hline & INEEL-B & No Pool & 0 & BWR \\
\hline & INEEL-P & No Pool & 0 & PWR \\
\hline & MGR1-Bare P & No Pool & 0 & \\
\hline & MGR1-DOE & No Pool & 0 & \\
\hline & INEEL-NAVY-15' & No Pool & 0 & NAVYL \\
\hline & MGR1-HLW & No Pool & 0 & \\
\hline & HANFORD-DSNF-MCO & No Pool & 0 & MCO \\
\hline & HANFORD-DSNF-15' & No Pool & 0 & DSNFL \\
\hline & SRS-DSNF-10' & No Pool & 0 & DSNF \\
\hline & INEEL-NAVY-10' & No Pool & 0 & NAVY \\
\hline & HANFORD-DSNF-10' & No Pool & 0 & DSNF \\
\hline \multirow{3}{*}{$\begin{array}{l}\text { Public Service Electric } \\
\text { and Gas Co (PSEG) }\end{array}$} & SALEM 1 & 1632 & 193 & PWR \\
\hline & $\begin{array}{ll}\text { SALEM } \quad 2 \\
\end{array}$ & 1632 & 193 & PWR \\
\hline & HOPE CREEK & 4006 & 764 & BWR \\
\hline Constellation Energy & RE GINNA & 1321 & 121 & PWR \\
\hline
\end{tabular}




\begin{tabular}{|c|c|c|c|c|}
\hline Utility & Pool Name & Capacity & $\begin{array}{l}\text { Fuel } \\
\text { Core } \\
\text { Reserve }\end{array}$ & $\begin{array}{l}\text { Fuel } \\
\text { Type }\end{array}$ \\
\hline $\begin{array}{l}\text { Sacramento Municipal } \\
\text { Utility District (SMUD) }\end{array}$ & RANCHO SECO 1 & 1080 & 0 & PWR \\
\hline $\begin{array}{l}\text { South Carolina Electric } \\
\text { and Gas Co }\end{array}$ & VC SUMMER 1 & 1712 & 157 & PWR \\
\hline \multirow{6}{*}{$\begin{array}{l}\text { Southern California } \\
\text { Edison }\end{array}$} & SAN ONOFRE 2 & 1542 & 217 & PWR \\
\hline & SAN ON 1 IN 2 & 70 & 0 & PWR \\
\hline & SAN ONOFRE 1 & 216 & 0 & PWR \\
\hline & SAN ONOFRE 3 & 1542 & 217 & PWR \\
\hline & SOnfo1 at MORRIS & No Pool & 0 & PWR \\
\hline & SAN ON 1 IN 3 & 118 & 0 & PWR \\
\hline \multirow{4}{*}{$\begin{array}{l}\text { Tennessee Valley } \\
\text { Authority (TVA) }\end{array}$} & BROWNS FERRY1 & 6942 & 764 & BWR \\
\hline & WATTS BAR 1 & 1610 & 193 & PWR \\
\hline & BROWNS FERRY3 & 3471 & 764 & BWR \\
\hline & SEQUOYAH 1 & 2091 & 193 & PWR \\
\hline TXU Electric Co & COMANCHE PK 1 & 3373 & 193 & PWR \\
\hline Ameren & CALLAWAY 1 & 2642 & 193 & PWR \\
\hline Energy Northwest & COLUMBIA & 2654 & 764 & BWR \\
\hline $\begin{array}{l}\text { Wisconsin Electric } \\
\text { Power Co }\end{array}$ & POINT BEACH 1 & 1502 & 121 & PWR \\
\hline Dominion Resources & KEWAUNEE & 1196 & 121 & PWR \\
\hline $\begin{array}{l}\text { Yankee Atomic Electric } \\
\text { Co }\end{array}$ & YANKEE-ROWE 1 & 721 & 0 & PWR \\
\hline $\begin{array}{l}\text { Indiana Michigan Power } \\
\text { Co }\end{array}$ & DONALD COOK & 3613 & 193 & PWR \\
\hline
\end{tabular}


Table 9 Status of Used Fuel Storage at Commercial Nuclear Power Plants. (NEI)

(* Facility with Dry Cask Storage as of 1/2010,

\# Facility Dry Storage in planning/licensing/construction)

\begin{tabular}{|c|c|c|c|c|}
\hline $\begin{array}{l}\text { Dry } \\
\text { Storage } \\
\text { Availability }\end{array}$ & Plant & Year & State & Type \\
\hline$*$ & Robinson 2 & 1987 & SC & PWR \\
\hline$*$ & Surry 1 & 1987 & VA & PWR \\
\hline$*$ & Surry 2 & 1987 & VA & PWR \\
\hline$*$ & Oconee 1 & 1990 & SC & PWR \\
\hline$*$ & Oconee 2 & 1990 & SC & PWR \\
\hline$*$ & Oconee 3 & 1990 & SC & PWR \\
\hline$*$ & Palisades & 1992 & MI & PWR \\
\hline$*$ & Calvert Cliffs 1 & 1994 & MD & PWR \\
\hline$*$ & Calvert Cliffs 2 & 1994 & MD & PWR \\
\hline$*$ & Prairie Island 1 & 1994 & $\mathrm{MN}$ & PWR \\
\hline * & Prairie Island 2 & 1994 & MN & PWR \\
\hline$*$ & Arkansas Nuclear One 1 & 1995 & $\mathrm{AR}$ & PWR \\
\hline$*$ & Davis-Besse & 1995 & $\mathrm{OH}$ & PWR \\
\hline$*$ & Point Beach 1 & 1995 & WI & PWR \\
\hline$*$ & Point Beach 2 & 1995 & WI & PWR \\
\hline * & Arkansas Nuclear One 2 & 1996 & $\mathrm{AR}$ & PWR \\
\hline$*$ & Hatch 1 & 1998 & GA & BWR \\
\hline$*$ & Hatch 2 & 1998 & GA & BWR \\
\hline$*$ & North Anna 1 & 1998 & VA & PWR \\
\hline$*$ & North Anna 2 & 1998 & VA & PWR \\
\hline$*$ & Susquehanna 1 & 1998 & $\mathrm{PA}$ & BWR \\
\hline$*$ & Susquehanna 2 & 1998 & PA & BWR \\
\hline$*$ & Columbia Generating Station & 2000 & WA & BWR \\
\hline$*$ & Oyster Creek & 2000 & NJ & BWR \\
\hline$*$ & Peach Bottom 2 & 2000 & PA & BWR \\
\hline$*$ & Dresden 2 & 2001 & IL & BWR \\
\hline * & Peach Bottom 3 & 2001 & $\mathrm{PA}$ & BWR \\
\hline * & J.A. FitzPatrick & 2002 & NY & BWR \\
\hline$*$ & McGuire 1 & 2002 & NC & PWR \\
\hline$*$ & McGuire 2 & 2002 & NC & PWR \\
\hline$*$ & Dresden 3 & 2003 & IL & BWR \\
\hline * & Palo Verde 2 & 2003 & $\mathrm{AZ}$ & PWR \\
\hline * & Palo Verde 3 & 2003 & $\mathrm{AZ}$ & PWR \\
\hline$*$ & Duane Arnold & 2004 & IA & BWR \\
\hline
\end{tabular}




\begin{tabular}{|c|c|c|c|c|}
\hline $\begin{array}{l}\text { Dry } \\
\text { Storage } \\
\text { Availability }\end{array}$ & Plant & Year & State & Type \\
\hline$*$ & Millstone 2 & 2004 & CT & PWR \\
\hline$*$ & Palo Verde 1 & 2004 & $\mathrm{AZ}$ & PWR \\
\hline$*$ & Quad Cities 1 & 2004 & IL & BWR \\
\hline$*$ & Quad Cities 2 & 2004 & IL & BWR \\
\hline$*$ & Browns Ferry 3 & 2005 & $\mathrm{AL}$ & BWR \\
\hline$*$ & Sequoyah 1 & 2005 & $\mathrm{TN}$ & PWR \\
\hline$*$ & Sequoyah 2 & 2005 & $\mathrm{TN}$ & PWR \\
\hline$*$ & Farley 1 & 2006 & $\mathrm{AL}$ & PWR \\
\hline$*$ & Fort Calhoun & 2006 & $\mathrm{NE}$ & PWR \\
\hline$*$ & Hope Creek & 2006 & NJ & BWR \\
\hline$*$ & River Bend & 2006 & LA & BWR \\
\hline$\#$ & Brunswick 2 & 2007 & NC & BWR \\
\hline$*$ & Grand Gulf & 2007 & MS & BWR \\
\hline$*$ & Indian Point 2 & 2007 & NY & PWR \\
\hline$*$ & Monticello & 2007 & $\mathrm{MN}$ & BWR \\
\hline$*$ & San Onofre 2 & 2007 & CA & PWR \\
\hline$*$ & Vermont Yankee & 2007 & VT & BWR \\
\hline$*$ & Browns Ferry 1 & 2008 & $\mathrm{AL}$ & BWR \\
\hline$*$ & Browns Ferry 2 & 2008 & $\mathrm{AL}$ & BWR \\
\hline$\#$ & Brunswick 1 & 2008 & NC & BWR \\
\hline$*$ & Catawba 1 & 2008 & SC & PWR \\
\hline$*$ & Limerick 1 & 2008 & PA & BWR \\
\hline$*$ & Limerick 2 & 2008 & $\mathrm{PA}$ & BWR \\
\hline$*$ & San Onofre 3 & 2008 & CA & PWR \\
\hline$*$ & St. Lucie 1 & 2008 & FL & PWR \\
\hline$*$ & Catawba 2 & 2009 & SC & PWR \\
\hline \# & Ginna & 2009 & NY & PWR \\
\hline$*$ & Kewaunee & 2009 & WI & PWR \\
\hline$*$ & Seabrook & 2009 & $\mathrm{NH}$ & PWR \\
\hline$*$ & Diablo Canyon 1 & 2010 & CA & PWR \\
\hline$*$ & Farley 2 & 2010 & $\mathrm{AL}$ & PWR \\
\hline \# & Fermi 2 & 2010 & MI & BWR \\
\hline$*$ & Indian Point 3 & 2010 & $\mathrm{NY}$ & PWR \\
\hline$*$ & St. Lucie 2 & 2010 & FL & PWR \\
\hline \# & Byron 1 & 2011 & IL & PWR \\
\hline$\#$ & Byron 2 & 2011 & IL & PWR \\
\hline \# & Cooper & 2011 & NE & BWR \\
\hline
\end{tabular}




\begin{tabular}{|c|c|c|c|c|}
\hline $\begin{array}{l}\text { Dry } \\
\text { Storage } \\
\text { Availability }\end{array}$ & Plant & Year & State & Type \\
\hline * & Diablo Canyon 2 & 2011 & CA & PWR \\
\hline \# & Perry & 2011 & $\mathrm{OH}$ & BWR \\
\hline * & Salem 1 & 2011 & NJ & PWR \\
\hline \# & Waterford 3 & 2011 & LA & PWR \\
\hline \# & Braidwood 1 & 2012 & IL & PWR \\
\hline$\#$ & Braidwood 2 & 2012 & IL & PWR \\
\hline \# & LaSalle 1 & 2012 & IL & BWR \\
\hline$\#$ & LaSalle 2 & 2012 & IL & BWR \\
\hline \# & Nine Mile Point 1 & 2012 & NY & BWR \\
\hline \# & Pilgrim & 2012 & MA & BWR \\
\hline \# & Turkey Point 4 & 2012 & FL & PWR \\
\hline \# & Turkey Point 4 & 2012 & $\overline{F L}$ & PWR \\
\hline$\#$ & D.C. Cook 1 & 2013 & MI & PWR \\
\hline$\#$ & D.C. Cook 2 & 2013 & $\overline{\mathrm{MI}}$ & PWR \\
\hline \# & Clinton & 2014 & IL & BWR \\
\hline \# & Nine Mile Point 2 & 2014 & NY & BWR \\
\hline$\#$ & Beaver Valley 1 & 2015 & $\mathrm{PA}$ & PWR \\
\hline$\#$ & Crystal River 3 & 2015 & FL & PWR \\
\hline$*$ & Salem 2 & 2015 & $\mathrm{NJ}$ & PWR \\
\hline \# & Vogtle 2 & 2015 & GA & PWR \\
\hline \# & Commanche Peak 1 & 2017 & $\mathrm{TX}$ & PWR \\
\hline$\#$ & Commanche Peak 2 & 2017 & TX & PWR \\
\hline$\#$ & Vogtle 1 & 2017 & GA & PWR \\
\hline$\#$ & V.C. Summer & 2018 & $\mathrm{SC}$ & PWR \\
\hline$\#$ & Watts Bar & 2018 & TN & PWR \\
\hline \# & Callaway & 2019 & $\mathrm{MO}$ & PWR \\
\hline$\#$ & Wolf Creek & 2025 & KS & PWR \\
\hline$\#$ & Beaver Valley 2 & 2026 & $\mathrm{PA}$ & PWR \\
\hline$\#$ & South TX Project 1 & 2026 & $\mathrm{TX}$ & PWR \\
\hline$\#$ & South TX Project 2 & 2026 & TX & PWR \\
\hline \multirow[t]{2}{*}{ * } & Millstone 3 & End of Life & CT & PWR \\
\hline & Shearon Harris & End of Life & $\mathrm{NC}$ & PWR \\
\hline \# & Three Mile Island 1 & End of Life & $\mathrm{PA}$ & PWR \\
\hline * & Big Rock Point & Shutdown 1997 & MI & BWR \\
\hline \multirow[t]{2}{*}{ * } & Dresden 1 & Shutdown 1978 & IL & BWR \\
\hline & Fermi 1 & Shutdown 1972 & MI & -- \\
\hline * & Fort St. Vrain & Shutdown 1989 & $\mathrm{CO}$ & - \\
\hline
\end{tabular}




\begin{tabular}{|c|l|c|c|c|}
\hline $\begin{array}{l}\text { Dry } \\
\text { Storage } \\
\text { Availability }\end{array}$ & Plant & & & \\
\hline$*$ & Haddam Neck & Year & State & Type \\
\hline$*$ & Humboldt Bay & Shutdown 1996 & CT & PWR \\
\hline$*$ & Indian Point 1 & Shutdown 1976 & CA & BWR \\
\hline$\#$ & LaCrosse & Shutdown 1974 & NY & PWR \\
\hline$*$ & Maine Yankee & Shutdown 1987 & WI & BWR \\
\hline$*$ & Millstone 1 & Shutdown 1997 & ME & PWR \\
\hline & Peach Bottom 1 & Shutdown 1998 & CT & BWR \\
\hline$*$ & Rancho Seco & Shutdown 1974 & PA & -- \\
\hline$*$ & San Onofre 1 & Shutdown 1989 & CA & PWR \\
\hline & Three Mile Island 2 & Shutdown 1992 & CA & PWR \\
\hline$*$ & Trojan & Shutdown 1979 & PA & PWR \\
\hline$*$ & Yankee Rowe & Shutdown 1992 & OR & PWR \\
\hline$\#$ & Zion 1 & Shutdown 1991 & MA & PWR \\
\hline$\#$ & Zion 2 & Shutdown 1998 & IL & PWR \\
\hline & Shutdown 1998 & IL & PWR \\
\hline
\end{tabular}

* = Facilities with dry cask storage as of January 2010.

\# = Facilities with dry cask storage under construction or planning/licensing. 
Table 10 Dry Cask Storage in the U.S. by Vendor

\begin{tabular}{|c|c|c|c|c|c|c|c|}
\hline Vendor & Systems & Type & Reactor & Type & Utility & Casks & Assemblies \\
\hline \multirow[t]{4}{*}{ BFS/ES } & FuelSolutions & VSC-24 & ANO & PWR & Entergy & 24 & 576 \\
\hline & FuelSolutions & W150 & $\begin{array}{l}\text { Big Rock } \\
\text { Point }^{1,3}\end{array}$ & BWR & Consumers & 8 & 441 \\
\hline & FuelSolutions & VSC-24 & Palisades & PWR & Entergy & 18 & 432 \\
\hline & FuelSolutions & VSC-24 & Point Beach & PWR & FPL & 16 & 384 \\
\hline \multicolumn{6}{|c|}{ Total BFS/ES } & 66 & 1833 \\
\hline DOE & Foster Wheeler & MVDS & Ft. St. Vrain & HTGR & PS Colorado & & 1464 \\
\hline GNB & Castor & $\mathrm{V} / 21$ and X33 & Surry & PWR & Dominion & 26 & 558 \\
\hline \multirow[t]{24}{*}{ Holtec } & HI-STORM & MPC-24 & ANO & PWR & Entergy & 22 & 528 \\
\hline & HI-STORM & MPC-32 & ANO & PWR & Entergy & 16 & 512 \\
\hline & HI-STORM & MPC-32 & Byron & PWR & Exelon & 6 & 192 \\
\hline & HI-STORM & MPC-68 & Browns Ferry & BWR & TVA & 25 & 1700 \\
\hline & HI-STORM & MPC-68 & Columbia & BWR & Energy Northwest & 27 & 1836 \\
\hline & HI-STORM & MPC-32 & Diablo Canyon & PWR & PG\&E & 16 & 512 \\
\hline & HI-STORM & MPC-68 & Dresden & BWR & Exelon & 45 & 3060 \\
\hline & HI-STAR & MPC-68 & Dresden & BWR & Exelon & 4 & 272 \\
\hline & HI-STORM & MPC-32 & Farley & PWR & Southern Nuclear & 12 & 384 \\
\hline & HI-STORM & MPC-68 & Fitzpatrick & BWR & Entergy & 15 & 1020 \\
\hline & HI-STORM & MPC-68 & Grand Gulf & BWR & Entergy & 12 & 816 \\
\hline & HI-STORM & MPC-68 & Hatch & BWR & Southern Nuclear & 39 & 2652 \\
\hline & HI-STAR & MPC-68 & Hatch & BWR & Southern Nuclear & 3 & 204 \\
\hline & HI-STORM & MPC-68 & Hope Creek & BWR & PSE\&G & 16 & 1088 \\
\hline & HI-STAR & MPC-80 & Humboldt Bay ${ }^{1,3}$ & BWR & PG\&E & 5 & 390 \\
\hline & HI-STORM & MPC-32 & Indian Point $1^{3}$ & PWR & Entergy & 5 & 160 \\
\hline & HI-STORM & MPC-32 & Indian Point 2 & PWR & Entergy & 12 & 384 \\
\hline & HI-STORM & MPC-68 & LaSalle & BWR & Exelon & 4 & 272 \\
\hline & HI-STORM & MPC-68 & Quad Cities & BWR & Exelon & 25 & 1700 \\
\hline & HI-STORM & MPC-68 & River Bend & BWR & Entergy & 15 & 1020 \\
\hline & HI-STORM & MPC-68 & $\begin{array}{l}\text { Vermont } \\
\text { Yankee }\end{array}$ & BWR & Entergy & 5 & 340 \\
\hline & HI-STORM & MPC-32 & Salem & PWR & PSE\&G & 4 & 128 \\
\hline & HI-STORM & MPC-32 & Sequoyah & PWR & TVA & 26 & 832 \\
\hline & TranStor cask & MPC-24E/EF & Trojan & PWR & Portland GE & 34 & 780 \\
\hline \multicolumn{6}{|c|}{ Total Holtec } & 393 & 20782 \\
\hline \multirow[t]{7}{*}{ NAC } & NAC-MPC & MPC-26 & Conn Yankee 2,3 & PWR & Ct. Yankee & 43 & 1019 \\
\hline & NAC-MPC & MPC-36 & Yankee Rowe $\mathrm{e}^{2,3}$ & PWR & YAEC & 16 & 533 \\
\hline & NAC-UMS & UMS-24 & Maine Yankee 2,3 & PWR & Maine Yankee & 64 & 1434 \\
\hline & NAC-UMS & UMS-24 & Catawba & PWR & Duke & 16 & 384 \\
\hline & NAC-UMS & UMS-24 & McGuire & PWR & Duke & 28 & 672 \\
\hline & NAC-UMS & UMS-24 & Palo Verde & PWR & APS & 79 & 1896 \\
\hline & NAC-I28 & NAC-I28 & Surry & PWR & Dominion & 2 & 56 \\
\hline \multicolumn{6}{|c|}{ Total NAC } & 248 & 5994 \\
\hline \multirow[t]{4}{*}{$\mathbf{T N}$} & NUHOMS & 61BTH & Brunswick & BWR & Progress & 6 & 366 \\
\hline & NUHOMS & $24 \mathrm{P}$ & Calvert Cliffs & PWR & Constellation & 48 & 1152 \\
\hline & NUHOMS & $32 \mathrm{P}$ & Calvert Cliffs & PWR & Constellation & 18 & 576 \\
\hline & NUHOMS & $61 \mathrm{BT}$ & Cooper & BWR & NPPD & 8 & 488 \\
\hline
\end{tabular}




\begin{tabular}{|c|c|c|c|c|c|c|c|}
\hline Vendor & Systems & Type & Reactor & Type & Utility & Casks & Assemblies \\
\hline & NUHOMS & $24 \mathrm{P}$ & Davis-Besse & PWR & FirstEnergy & 3 & 72 \\
\hline & NUHOMS & 61BT & Duane Arnold & BWR & FPL & 10 & 610 \\
\hline & NUHOMS & $32 \mathrm{PT}$ & Fort Calhoun & PWR & OPPD & 10 & 320 \\
\hline & NUHOMS & $32 \mathrm{PT}$ & Ginna & PWR & Constellation & 4 & 128 \\
\hline & NUHOMS & $12 \mathrm{~T}$ & INEEL & PWR & DOE & 29 & 177 \\
\hline & NUHOMS & $32 \mathrm{PT}$ & Kewaunee & PWR & Dominion & 4 & 128 \\
\hline & NUHOMS & $61 \mathrm{BT}$ & Limerick & BWR & Exelon & 12 & 732 \\
\hline & NUHOMS & $32 \mathrm{PT}$ & Millstone & PWR & Dominion & 14 & 448 \\
\hline & NUHOMS & $61 \mathrm{BT}$ & Monticello & BWR & Xcel Energy & 10 & 610 \\
\hline & NUHOMS & 32PTH & North Anna & PWR & Dominion & 10 & 320 \\
\hline & NUHOMS & 24PHB & Oconee & PWR & Duke & 34 & 816 \\
\hline & NUHOMS & $24 \mathrm{P}$ & Oconee & PWR & Duke & 84 & 2016 \\
\hline & NUHOMS & 61BT & Oyster Creek & BWR & Exelon & 19 & 1159 \\
\hline & NUHOMS & 24PTH & Palisades & PWR & Entergy & 7 & 168 \\
\hline & NUHOMS & $32 \mathrm{PT}$ & Palisades & PWR & Entergy & 11 & 352 \\
\hline & NUHOMS & $32 \mathrm{PT}$ & Point Beach & PWR & FPL & 14 & 448 \\
\hline & NUHOMS & $24 \mathrm{PT}$ & Rancho Seco $^{1}$ & PWR & SMUD & 22 & 493 \\
\hline & NUHOMS & 24PTH & Robinson & PWR & Progress & 8 & 192 \\
\hline & NUHOMS & $7 \mathrm{P}$ & Robinson & PWR & Progress & 8 & 56 \\
\hline & NUHOMS & 32PTH & Seabrook & PWR & FPL & 6 & 192 \\
\hline & NUHOMS & 24PT1 & SONGS $1^{1,3}$ & PWR & $\begin{array}{l}\text { Southern Cal } \\
\text { Edison }\end{array}$ & 18 & 395 \\
\hline & NUHOMS & $24 \mathrm{PT} 4$ & SONGS $2 \& 3$ & PWR & $\begin{array}{l}\text { Southern Cal } \\
\text { Edison }\end{array}$ & 22 & 528 \\
\hline & NUHOMS & 32PTH & St. Lucie & PWR & FPL & 11 & 352 \\
\hline & NUHOMS & $32 \mathrm{PTH}$ & Surry & PWR & Dominion & 12 & 384 \\
\hline & NUHOMS & $52 \mathrm{~B}$ & Susquehanna & BWR & PPL & 27 & 1404 \\
\hline & NUHOMS & 61BT & Susquehanna & BWR & PPL & 40 & 2440 \\
\hline & $\begin{array}{l}\text { TN Metal } \\
\text { Casks }\end{array}$ & TN-32 & McGuire & PWR & Duke & 10 & 320 \\
\hline & $\begin{array}{l}\text { TN Metal } \\
\text { Casks }\end{array}$ & TN-32 & North Anna & PWR & Dominion & 27 & 864 \\
\hline & $\begin{array}{l}\text { TN Metal } \\
\text { Casks }\end{array}$ & TN-68 & Peach Bottom & BWR & Exelon & 49 & 3332 \\
\hline & $\begin{array}{l}\text { TN Metal } \\
\text { Casks }\end{array}$ & TN-40 & Praire Island & PWR & Xcel Energy & 29 & 1160 \\
\hline & $\begin{array}{l}\text { TN Metal } \\
\text { Casks }\end{array}$ & TN-32 & Surry & PWR & Dominion & 26 & 832 \\
\hline \multicolumn{6}{|l|}{ Total TN } & 670 & 24030 \\
\hline Westinghouse & MC-10 & MC-10 & Surry & PWR & Dominion & 1 & 24 \\
\hline \multicolumn{6}{|c|}{ Overall Totals: } & 1404 & 54685 \\
\hline \multicolumn{8}{|c|}{$\begin{array}{l}{ }^{2} \mathrm{CY} \text { has } 3 \text { casks storing GTCC waste; Yankee Rowe has one and Maine Yankee has four casks } \\
{ }^{3} \text { All spent fuel from the shutdown plant. }\end{array}$} \\
\hline
\end{tabular}


Table 11 Dry Cask Storage in the U.S. by Utility

\begin{tabular}{|c|c|c|c|c|c|c|c|}
\hline Utility & Reactor & Type & Vendor & Cask System & Canister Type & $\begin{array}{c}\text { Total } \\
\text { Loaded }\end{array}$ & $\begin{array}{c}\text { Assemblies } \\
\text { Stored }\end{array}$ \\
\hline APS & Palo Verde & PWR & NAC & NAC-UMS & UMS-24 & 79 & 1896 \\
\hline Constellation & Calvert Cliffs & PWR & TN & NUHOMS & $24 \mathrm{P}$ & 48 & 1152 \\
\hline Constellation & Calvert & PWR & TN & NUHOMS & $32 \mathrm{P}$ & 18 & 576 \\
\hline Constellation & Ginna & PWR & $\mathrm{TN}$ & NUHOMS & $32 \mathrm{PT}$ & 4 & 128 \\
\hline Consumers & $\begin{array}{l}\text { Big Rock } \\
\text { Point }^{1}\end{array}$ & BWR & $\mathrm{BFS} / \mathrm{ES}$ & FuelSolutions & W150 & 8 & 441 \\
\hline Ct. Yankee & Conn Yankee $^{1}$ & PWR & NAC & NAC-MPC & MPC-26 & 43 & 1019 \\
\hline DOE & & INEEL & $\mathrm{TN}$ & NUHOMS & $12 \mathrm{~T}$ & 29 & 177 \\
\hline Dominion & Kewaunee & PWR & TN & NUHOMS & $32 \mathrm{PT}$ & 4 & 128 \\
\hline Dominion & Millstone & PWR & $\mathrm{TN}$ & NUHOMS & $32 \mathrm{PT}$ & 14 & 448 \\
\hline Dominion & North Anna & PWR & $\mathrm{TN}$ & TN Metal Casks & TN-32 & 27 & 864 \\
\hline Dominion & North Anna & PWR & $\mathrm{TN}$ & NUHOMS & 32PTH & 10 & 320 \\
\hline Dominion & Surry & PWR & GNB & Castor & $\mathrm{V} / 21$ and X33 & 26 & 558 \\
\hline Dominion & Surry & PWR & NAC & NAC-I28 & NAC-I28 & 2 & 56 \\
\hline Dominion & Surry & PWR & $\mathrm{TN}$ & NUHOMS & 32PTH & 12 & 384 \\
\hline Dominion & Surry & PWR & $\mathrm{TN}$ & TN Metal Casks & TN-32 & 26 & 832 \\
\hline Dominion & Surry & PWR & $\mathrm{W}$ & MC-10 & MC-10 & 1 & 24 \\
\hline Duke & Catawba & PWR & NAC & NAC-UMS & UMS-24 & 16 & 384 \\
\hline Duke & McGuire & PWR & NAC & NAC-UMS & UMS-24 & 28 & 672 \\
\hline Duke & McGuire & PWR & $\mathrm{TN}$ & TN Metal Casks & TN-32 & 10 & 320 \\
\hline Duke & Oconee & PWR & TN & NUHOMS & $24 \mathrm{P}$ & 84 & 2016 \\
\hline Duke & Oconee & PWR & $\mathrm{TN}$ & NUHOMS & 24PHB & 34 & 816 \\
\hline $\begin{array}{l}\text { Energy } \\
\text { Northwest }\end{array}$ & Columbia & BWR & Holtec & HI-STORM & MPC-68 & 27 & 1836 \\
\hline Entergy & ANO & PWR & BFS/ES & FuelSolutions & VSC-24 & 24 & 576 \\
\hline Entergy & ANO & PWR & Holtec & HI-STORM & MPC-24 & 22 & 528 \\
\hline Entergy & ANO & PWR & Holtec & HI-STORM & MPC-32 & 16 & 512 \\
\hline Entergy & Fitzpatrick & BWR & Holtec & HI-STORM & MPC-68 & 15 & 1020 \\
\hline Entergy & Grand Gulf & BWR & Holtec & HI-STORM & MPC-68 & 12 & 816 \\
\hline Entergy & Indian Point 1 & PWR & Holtec & HI-STORM & MPC-32 & 5 & 160 \\
\hline Entergy & Indian Point 2 & PWR & Holtec & HI-STORM & MPC-32 & 12 & 384 \\
\hline Entergy & Palisades & PWR & $\mathrm{BFS} / \mathrm{ES}$ & FuelSolutions & VSC-24 & 18 & 432 \\
\hline Entergy & Palisades & PWR & TN & NUHOMS & $24 \mathrm{PTH}$ & 7 & 168 \\
\hline Entergy & Palisades & PWR & $\mathrm{TN}$ & NUHOMS & $32 \mathrm{PT}$ & 11 & 352 \\
\hline Entergy & River Bend & BWR & Holtec & HI-STORM & MPC-68 & 15 & 1020 \\
\hline Entergy & $\begin{array}{l}\text { Vermont } \\
\text { Yankee }\end{array}$ & BWR & Holtec & HI-STORM & MPC-68 & 5 & 340 \\
\hline Exelon & Byron & PWR & Holtec & HI-STORM & MPC-32 & 6 & 192 \\
\hline Exelon & Dresden & BWR & Holtec & HI-STORM & MPC-68 & 45 & 3060 \\
\hline Exelon & Dresden & BWR & Holtec & HI-STAR & MPC-68 & 4 & 272 \\
\hline Exelon & LaSalle & BWR & Holtec & HI-STORM & MPC-68 & 4 & 272 \\
\hline Exelon & Limerick & BWR & $\mathrm{TN}$ & NUHOMS & 61BT & 12 & 732 \\
\hline Exelon & Oyster Creek & BWR & $\mathrm{TN}$ & NUHOMS & 61BT & 19 & 1159 \\
\hline Exelon & Peach Bottom & BWR & $\mathrm{TN}$ & TN Metal Casks & TN-68 & 49 & 3332 \\
\hline Exelon & Quad Cities & BWR & Holtec & HI-STORM & MPC-68 & 25 & 1700 \\
\hline FirstEnergy & Davis-Besse & PWR & TN & NUHOMS & $24 \mathrm{P}$ & 3 & 72 \\
\hline FPL & Duane Arnold & BWR & $\mathrm{TN}$ & NUHOMS & $61 \mathrm{BT}$ & 10 & 610 \\
\hline
\end{tabular}




\begin{tabular}{|c|c|c|c|c|c|c|c|}
\hline Utility & Reactor & Type & Vendor & Cask System & Canister Type & $\begin{array}{c}\text { Total } \\
\text { Loaded }\end{array}$ & $\begin{array}{c}\text { Assemblies } \\
\text { Stored }\end{array}$ \\
\hline FPL & Point Beach & PWR & BFS/ES & FuelSolutions & VSC-24 & 16 & 384 \\
\hline FPL & Point Beach & PWR & $\mathrm{TN}$ & NUHOMS & $32 \mathrm{PT}$ & 14 & 448 \\
\hline FPL & St. Lucie & PWR & $\mathrm{TN}$ & NUHOMS & 32PTH & 11 & 352 \\
\hline FPL & Seabrook & PWR & $\mathrm{TN}$ & NUHOMS & 32PTH & 6 & 192 \\
\hline $\begin{array}{l}\text { Maine } \\
\text { Yankee }\end{array}$ & Maine Yankee $^{1}$ & PWR & NAC & NAC-UMS & UMS-24 & 64 & 1434 \\
\hline NPPD & Cooper & BWR & $\mathrm{TN}$ & NUHOMS & $61 \mathrm{BT}$ & 8 & 488 \\
\hline OPPD & Fort Calhoun & PWR & $\mathrm{TN}$ & NUHOMS & $32 \mathrm{PT}$ & 10 & 320 \\
\hline Portland GE & Trojan & PWR & Holtec & TranStor cask & MPC-24E/EF & 34 & 780 \\
\hline PPL & Susquehanna & BWR & $\mathrm{TN}$ & NUHOMS & $52 \mathrm{~B}$ & 27 & 1404 \\
\hline PPL & Susquehanna & BWR & $\mathrm{TN}$ & NUHOMS & $61 \mathrm{BT}$ & 40 & 2440 \\
\hline Progress & Brunswick & BWR & $\mathrm{TN}$ & NUHOMS & 61BTH & 6 & 366 \\
\hline Progress & Robinson & PWR & $\mathrm{TN}$ & NUHOMS & $7 \mathrm{P}$ & 8 & 56 \\
\hline Progress & Robinson & PWR & $\mathrm{TN}$ & NUHOMS & $24 \mathrm{PTH}$ & 8 & 192 \\
\hline PS Colorado & Ft. St Vrain & HTGR & DOE & Foster Wheeler & MVDS & & 1464 \\
\hline PSE\&G & Hope Creek & BWR & Holtec & HI-STORM & MPC-68 & 16 & 1088 \\
\hline PSE\&G & Salem & PWR & Holtec & HI-STORM & MPC-32 & 4 & 128 \\
\hline PG\&E & Diablo Canyon & PWR & Holtec & HI-STORM & MPC-32 & 16 & 512 \\
\hline PG\&E & Humboldt Bay $^{1}$ & BWR & Holtec & HI-STAR & MPC-80 & 5 & 390 \\
\hline SMUD & Rancho Seco $^{1}$ & PWR & $\mathrm{TN}$ & NUHOMS & $24 \mathrm{PT}$ & 22 & 493 \\
\hline $\begin{array}{l}\text { Southern Cal } \\
\text { Edison }\end{array}$ & SONGS $1^{1,2}$ & PWR & $\mathrm{TN}$ & NUHOMS & 24PT1 & 18 & 395 \\
\hline $\begin{array}{l}\text { Southern Cal } \\
\text { Edison }\end{array}$ & SONGS 2 & PWR & $\mathrm{TN}$ & NUHOMS & 24PT4 & 22 & 528 \\
\hline $\begin{array}{l}\text { Southern } \\
\text { Nuclear }\end{array}$ & Farley & PWR & Holtec & HI-STORM & MPC-32 & 12 & 384 \\
\hline Southern & Hatch & BWR & Holtec & HI-STORM & MPC-68 & 39 & 2652 \\
\hline Southern & Hatch & BWR & Holtec & HI-STAR & MPC-68 & 3 & 204 \\
\hline TVA & Browns Ferry & BWR & Holtec & HI-STORM & MPC-68 & 25 & 1700 \\
\hline TVA & Sequoyah & PWR & Holtec & HI-STORM & MPC-32 & 26 & 832 \\
\hline Xcel Energy & Prairie Island & PWR & $\mathrm{TN}$ & TN Metal Casks & $\mathrm{TN}-40$ & 29 & 1160 \\
\hline Xcel & Monticello & BWR & $\mathrm{TN}$ & NUHOMS & $61 \mathrm{BT}$ & 10 & 610 \\
\hline YAEC & Yankee Rowe $^{2}$ & PWR & NAC & NAC-MPC & MPC-36 & 16 & 533 \\
\hline \multicolumn{6}{|l|}{ Overall Totals: } & 1404 & 54685 \\
\hline
\end{tabular}


Table 12 General License Termination data ${ }^{\dagger}$

\begin{tabular}{|c|c|c|c|c|c|c|c|}
\hline \multirow{2}{*}{ Reactor } & \multicolumn{3}{|c|}{ License Termination (Yr) } & \multirow{2}{*}{ Reactor } & \multicolumn{3}{|c|}{ License Termination (Yr) } \\
\hline & Initially & Extended & Status & & Initially & Extended & Status \\
\hline ARKANSAS NUCLEAR 1 & 2014 & 2034 & G & MILLSTONE 3 & 2025 & 2045 & G \\
\hline ARKANSAS NUCLEAR 2 & 2018 & 2038 & $\mathrm{G}$ & MONTICELLO & 2010 & 2030 & $\mathrm{G}$ \\
\hline BEAVER VALLEY 1 & 2016 & 2036 & A & NINE MILE POINT 1 & 2009 & 2029 & G \\
\hline BEAVER VALLEY 2 & 2027 & 2047 & A & NINE MILE POINT 2 & 2026 & 2046 & G \\
\hline BRAIDWOOD 1 & 2026 & 2046 & No & NORTH ANNA 1 & 2018 & 2038 & $\mathrm{G}$ \\
\hline BRAIDWOOD 2 & 2027 & 2047 & No & NORTH ANNA 2 & 2020 & 2040 & $\mathrm{G}$ \\
\hline BROWNS FERRY 1 & 2013 & 2033 & $\mathrm{G}$ & OCONEE 1 & 2013 & 2033 & $\mathrm{G}$ \\
\hline BROWNS FERRY 2 & 2014 & 2034 & $\mathrm{G}$ & OCONEE 2 & 2013 & 2033 & G \\
\hline BROWNS FERRY 3 & 2016 & 2036 & G & OCONEE 3 & 2014 & 2034 & G \\
\hline BRUNSWICK 1 & 2016 & 2036 & G & OYSTER CREEK & 2009 & 2029 & A \\
\hline BRUNSWICK 2 & 2014 & 2034 & G & PALISADES & 2011 & 2031 & G \\
\hline BYRON 1 & 2024 & 2044 & No & PALO VERDE 1 & 2025 & 2045 & A \\
\hline BYRON 2 & 2026 & 2046 & No & PALO VERDE 2 & 2026 & 2046 & A \\
\hline CALLAWAY & 2024 & 2044 & No & PALO VERDE 3 & 2027 & 2047 & A \\
\hline CALVERT CLIFFS 1 & 2014 & 2034 & $\mathrm{G}$ & PEACH BOTTOM 2 & 2013 & 2033 & G \\
\hline CALVERT CLIFFS 2 & 2016 & 2036 & $\mathrm{G}$ & PEACH BOTTOM 3 & 2014 & 2034 & G \\
\hline CATAWBA 1 & 2024 & 2043 & G & PERRY 1 & 2026 & 2046 & No \\
\hline CATAWBA 2 & 2026 & 2043 & $G$ & PILGRIM 1 & 2012 & 2032 & A \\
\hline CLINTON 1 & 2026 & 2046 & No & POINT BEACH 1 & 2010 & 2030 & G \\
\hline COMANCHE PEAK 1 & 2030 & 2050 & No & POINT BEACH 2 & 2013 & 2033 & G \\
\hline COMANCHE PEAK 2 & 2033 & 2053 & No & PRAIRIE ISLAND 1 & 2013 & 2033 & A \\
\hline COOK 1 & 2014 & 2034 & $\mathrm{G}$ & PRAIRIE ISLAND 2 & 2014 & 2034 & A \\
\hline COOK 2 & 2017 & 2037 & $\mathrm{G}$ & QUAD CITIES 1 & 2012 & 2032 & G \\
\hline COOPER STATION & 2014 & 2034 & A & QUAD CITIES 2 & 2012 & 2032 & G \\
\hline CRYSTAL RIVER 3 & 2016 & 2036 & No & RIVER BEND 1 & 2025 & 2045 & No \\
\hline DAVIS-BESSE & 2017 & 2037 & No & ROBINSON 2 & 2010 & 2030 & G \\
\hline DIABLO CANYON 1 & 2024 & 2044 & No & SALEM 1 & 2016 & 2036 & No \\
\hline DIABLO CANYON 2 & 2025 & 2045 & No & SALEM 2 & 2020 & 2040 & No \\
\hline DRESDEN 2 & 2009 & 2029 & $\mathrm{G}$ & SAN ONOFRE 2 & 2022 & 2042 & No \\
\hline DRESDEN 3 & 2011 & 2031 & G & SAN ONOFRE 3 & 2022 & 2042 & No \\
\hline DUANE ARNOLD & 2014 & 2034 & A & SEABROOK & 2030 & 2050 & No \\
\hline ENRICO FERMI 2 & 2025 & 2045 & No & SEQUOYAH 1 & 2020 & 2040 & No \\
\hline FARLEY 1 & 2017 & 2037 & $G$ & SEQUOYAH 2 & 2021 & 2041 & No \\
\hline FARLEY 2 & 2021 & 2041 & G & SOUTH TEXAS 1 & 2027 & 2047 & No \\
\hline FITZPATRICK & 2014 & 2034 & G & SOUTH TEXAS 2 & 2028 & 2048 & No \\
\hline FORT CALHOUN & 2013 & 2033 & G & ST LUCIE 1 & 2016 & 2036 & G \\
\hline GINNA & 2009 & 2029 & G & ST LUCIE 2 & 2023 & 2043 & G \\
\hline GRAND GULF 1 & 2024 & 2044 & No & SUMMER UNIT 1 & 2022 & 2042 & G \\
\hline HARRIS 1 & 2026 & 2046 & G & SURRY 1 & 2012 & 2032 & G \\
\hline HATCH 1 & 2014 & 2034 & G & SURRY 2 & 2013 & 2033 & G \\
\hline HATCH 2 & 2018 & 2038 & G & SUSQUEHANNA 1 & 2022 & 2042 & A \\
\hline HOPE CREEK & 2026 & 2046 & No & SUSQUEHANNA 2 & 2024 & 2044 & A \\
\hline INDIAN POINT 2 & 2013 & 2033 & A & THREE MILE ISLAND 1 & 2014 & 2034 & A \\
\hline INDIAN POINT 3 & 2015 & 2035 & A & TURKEY POINT 3 & 2012 & 2032 & G \\
\hline KEWAUNEE & 2013 & 2033 & A & TURKEY POINT 4 & 2013 & 2033 & G \\
\hline LASALLE COUNTY 1 & 2022 & 2042 & No & VOGTLE 1 & 2027 & 2047 & A \\
\hline LASALLE COUNTY 2 & 2023 & 2043 & No & VOGTLE 2 & 2029 & 2049 & A \\
\hline LIMERICK 1 & 2024 & 2044 & No & VT YANKEE & 2012 & 2032 & A \\
\hline LIMERICK 2 & 2029 & 2049 & No & COLUMBIA & 2023 & 2043 & No \\
\hline MCGUIRE 1 & 2021 & 2041 & G & WATERFORD 3 & 2024 & 2044 & No \\
\hline MCGUIRE 2 & 2023 & 2043 & G & WATTS BAR 1 & 2035 & 2055 & No \\
\hline MILLSTONE 2 & 2015 & 2035 & G & WOLFCREEK 1 & 2025 & 2045 & G \\
\hline \multicolumn{8}{|c|}{ Note: Status terms are G =Granted LE. A = Applied for LE. and No = No application for LE has been submitted. } \\
\hline
\end{tabular}


Table 13 List of Shutdown Reactors Greater than 100 MW

\begin{tabular}{|l|l|l|}
\hline Zion 1 \& 2 & IL & $1973-1998$ \\
\hline Millstone 1 & CT & $1970-1998$ \\
\hline Maine Yankee & ME & $1972-1997$ \\
\hline Connecticut Yankee & CT & $1967-1997$ \\
\hline Trojan & OR & $1976-1993$ \\
\hline San Onofre 1 & CA & $1968-1992$ \\
\hline Yankee Rowe & MA & $1961-1992$ \\
\hline Shoreham & NY & $1989-1989$ \\
\hline Fort St. Vrain & CO & $1979-1989$ \\
\hline Rancho Seco & CA & $1975-1989$ \\
\hline TMI-2 & PA & $1978-1979$ \\
\hline Dresden 1 & IL & $1960-1978$ \\
\hline Indian Point 1 & NY & $1962-1974$ \\
\hline
\end{tabular}


Table 14 Decommissioning Status for Shutdown Power Reactors

\begin{tabular}{|c|c|c|c|c|c|c|}
\hline Reactor & Location & Shutdown & Status & $\begin{array}{c}\text { Fuel } \\
\text { Onsite }\end{array}$ & $\begin{array}{l}\text { Storage } \\
\text { Type }\end{array}$ & $\begin{array}{r}\text { Quantity } \\
\text { (MTUs) }\end{array}$ \\
\hline Big Rock Point & Charlevoix, MI & $8 / 97$ & ISFSI Only & Yes & Dry Cask & 58 \\
\hline CVTR & Parr, SC & $1 / 67$ & License Terminated & No & - & - \\
\hline Dresden $1^{*}$ & Morris, IL & $10 / 31 / 78$ & SAFSTOR & Yes & Dry Cask & 69 \\
\hline Fermi 1 & Monroe Co., MI & $9 / 22 / 72$ & SAFSTOR/DECON & No & - & - \\
\hline Fort St. Vrain & Platteville, CO & 8/18/89 & License Terminated & Yes & Dry Cask & 25 \\
\hline GE VBWR & Alameda Co., CA & $12 / 9 / 63$ & SAFSTOR & No & - & - \\
\hline Haddam Neck & Haddam Neck, CT & $7 / 22 / 96$ & ISFSI Only & Yes & Dry Cask & 414 \\
\hline Humboldt Bay 3 & Eureka, CA & $7 / 02 / 76$ & DECON & Yes & Dry Cask & 31 \\
\hline Indian Point $1^{*}$ & Buchanan, NY & $10 / 31 / 74$ & SAFSTOR & Yes & Dry Cask & 33 \\
\hline LaCrosse & LaCrosse, WI & $4 / 30 / 87$ & SAFSTOR & Yes & Pool & 38 \\
\hline Main Yankee & Bath, ME & $12 / 96$ & ISFSI Only & Yes & Dry Cask & 542 \\
\hline Millstone 1* & Waterford, CT & $11 / 04 / 95$ & SAFSTOR & Yes & Dry Cask & 522 \\
\hline N.S. Savannah & Norfolk, VA & 1970 & SAFSTOR & No & - & - \\
\hline Pathfinder & Sioux Falls, SD & $9 / 16 / 67$ & DECON NRC Part & No & - & - \\
\hline Peach Bottom 1 & York Co., PA & $10 / 31 / 74$ & SAFSTOR & No & - & - \\
\hline Rancho Seco & Sacramento, CA & $6 / 7 / 89$ & ISFSI Only & Yes & Dry Cask & 228 \\
\hline San Onofre 1* & San Clemente, CA & 11/30/92 & DECON & Yes & Dry Cask & 146 \\
\hline Saxton & Saxton, PA & $5 / 72$ & License Terminated & No & - & - \\
\hline Shoreham & Suffolk Co., NY & $6 / 28 / 89$ & License Terminated & No & - & - \\
\hline Three Mile Island 2 & Middletown, PA & $3 / 28 / 79$ & SAFSTOR* & No & - & - \\
\hline Trojan & Portland, OR & $11 / 9 / 92$ & ISFSI Only & Yes & Dry Cask & 345 \\
\hline Yankee Rowe & Franklin Co., MA & $10 / 1 / 91$ & ISFSI Only & Yes & Dry Cask & 122 \\
\hline Zion 2 & Zion, IL & $2 / 98$ & SAFSTOR & Yes & \multirow{2}{*}{$\begin{array}{l}\text { Combined } \\
\text { Pool }\end{array}$} & \multirow{2}{*}{1,019} \\
\hline Zion 1 & Zion, IL & $2 / 98$ & SAFSTOR & Yes & & \\
\hline \multicolumn{6}{|c|}{ Total MTUs } & 3,567 \\
\hline \multicolumn{6}{|c|}{ Sources: ACI Nuclear, NEI, and NRC 2011.} & \\
\hline
\end{tabular}


Inventory and Description of Commercial Reactor Fuels within the United States

Table 15 Cumulative Commercial Reactor Discharges

\begin{tabular}{|c|c|c|c|c|c|c|c|c|}
\hline \multirow[t]{2}{*}{ Reactor Name } & \multirow{2}{*}{$\begin{array}{l}\text { Year First } \\
\text { discharge }\end{array}$} & \multirow{2}{*}{$\begin{array}{c}\text { Discharge } \\
\text { Date By } \\
\text { Year } \\
\text { 2011* }\end{array}$} & \multicolumn{2}{|c|}{$\begin{array}{c}\text { Estimated } \\
\text { Cumulative } \\
\text { Discharges } 2011 \\
\end{array}$} & \multicolumn{2}{|c|}{$\begin{array}{c}\text { Projected } \\
\text { Cumulative } \\
\text { Discharges 2021 }\end{array}$} & \multicolumn{2}{|c|}{$\begin{array}{c}\text { Projected } \\
\text { Cumulative } \\
\text { Discharges 2031 }\end{array}$} \\
\hline & & & MTHM & \# Assm & MTHM & \# Assm & MTHM & \# Assm \\
\hline 3 Mile Island 1 & 1976 & 2011 & 584 & 1242 & 740 & 1564 & 899 & 1891 \\
\hline Arkansas Nuclear 1 & 1977 & 2011 & 647 & 1398 & 797 & 1721 & 952 & 2054 \\
\hline Arkansas Nuclear 2 & 1981 & 2011 & 652 & 1555 & 893 & 2119 & 1089 & 2576 \\
\hline Beaver Valley 1 & 1979 & 2011 & 598 & 1294 & 802 & 1736 & 983 & 2129 \\
\hline Beaver Valley 2 & 1989 & 2011 & 442 & 956 & 628 & 1359 & 1564 & 3392 \\
\hline Big Rock 1 & 1968 & 1997 & 69 & 526 & \multicolumn{4}{|c|}{ Final Discharge in 1997} \\
\hline Braidwood 1 & 1989 & 2011 & 522 & 1238 & 707 & 527 & 986 & 2345 \\
\hline Braidwood 2 & 1990 & 2011 & 531 & 1260 & 766 & 1819 & 964 & 2293 \\
\hline Browns Ferry 1 & 1977 & 2011 & 501 & 2754 & 852 & 4742 & 1176 & 6580 \\
\hline Browns Ferry 2 & 1978 & 2011 & 853 & 4787 & 1143 & 6495 & 1390 & 7956 \\
\hline Browns Ferry 3 & 1978 & 2011 & 619 & 3489 & 930 & 5322 & 1209 & 6966 \\
\hline Brunswick 1 & 1979 & 2011 & 604 & 3350 & 815 & 4526 & 185 & 1038 \\
\hline Brunswick 2 & 1976 & 2011 & 647 & 3581 & 834 & 4628 & 1018 & 5660 \\
\hline Byron 1 & 1987 & 2011 & 604 & 1430 & 839 & 1988 & 1040 & 2468 \\
\hline Byron 2 & 1989 & 2011 & 572 & 1354 & 769 & 1823 & 998 & 2370 \\
\hline Callaway 1 & 1986 & 2011 & 712 & 1677 & 923 & 2183 & 1141 & 2705 \\
\hline Calvert Cliffs 1 & 1977 & 2011 & 623 & 1598 & 800 & 2033 & 959 & 2422 \\
\hline Calvert Cliffs 2 & 1978 & 2011 & 594 & 1525 & 762 & 1940 & 916 & 2321 \\
\hline Catawba 1 & 1986 & 2011 & 645 & 1446 & 913 & 2034 & 1143 & 2541 \\
\hline Catawba 2 & 1987 & 2011 & 506 & 2796 & 250 & 1401 & 470 & 2629 \\
\hline Clinton 1 & 1989 & 2011 & 598 & 1346 & 866 & 1933 & 1133 & 2521 \\
\hline Comanche Peak 1 & 1991 & 2011 & 537 & 1266 & 742 & 1758 & 955 & 2270 \\
\hline Comanche Peak 2 & 1994 & 2011 & 436 & 1047 & 672 & 1617 & 857 & 2062 \\
\hline Cook 1 & 1976 & 2011 & 787 & 1746 & 1017 & 2250 & 1190 & 2631 \\
\hline Cook 2 & 1979 & 2012 & 659 & 1548 & 838 & 1975 & 1026 & 2422 \\
\hline Cooper Station & 1976 & 2010 & 604 & 3308 & 732 & 4024 & 853 & 4700 \\
\hline DB 1 & 1982 & 2011 & 514 & 1085 & 722 & 1513 & 904 & 1888 \\
\hline Crystal River 3 & 1978 & 2011 & 569 & 1213 & 741 & 1569 & 895 & 1889 \\
\hline Diablo Canyon 1 & 1986 & 2010 & 587 & 1359 & 785 & 1827 & 976 & 2280 \\
\hline Diablo Canyon 2 & 1987 & 2011 & 557 & 1281 & 726 & 1678 & 882 & 2044 \\
\hline Dresden 1 & 1969 & 1978 & 91 & 892 & \multicolumn{4}{|c|}{ Final Discharge in 1978} \\
\hline Dresden 2 & 1974 & 2011 & 744 & 4207 & 930 & 5282 & 1158 & 6604 \\
\hline Dresden 3 & 1973 & 2011 & 696 & 3930 & 887 & 5039 & 1151 & 6572 \\
\hline Duane Arnold & 1975 & 2011 & 500 & 2766 & 619 & 3434 & 741 & 4120 \\
\hline Enrico Fermi 2 & 1989 & 2011 & 510 & 2907 & 724 & 4153 & 925 & 5326 \\
\hline Farley 1 & 1979 & 2011 & 651 & 1468 & 827 & 1886 & 984 & 2256 \\
\hline Farley 2 & 1982 & 2011 & 598 & 1358 & 752 & 1721 & 912 & 2100 \\
\hline Fitzpatrick & 1977 & 2011 & 623 & 3440 & 789 & 4364 & 936 & 5183 \\
\hline Fort Calhoun & 1975 & 2011 & 398 & 1088 & 492 & 1340 & 562 & 1529 \\
\hline GE Morris & 1970 & 1972 & 145 & 753 & \multicolumn{4}{|c|}{ Final Receipt in 1972} \\
\hline
\end{tabular}


Inventory and Description of Commercial Reactor Fuels within the United States

March 31, 2011

\begin{tabular}{|c|c|c|c|c|c|c|c|c|}
\hline \multirow[t]{2}{*}{ Reactor Name } & \multirow{2}{*}{$\begin{array}{l}\text { Year First } \\
\text { discharge }\end{array}$} & \multirow{2}{*}{$\begin{array}{c}\text { Discharge } \\
\text { Date By } \\
\text { Year } \\
201{ }^{*}\end{array}$} & \multicolumn{2}{|c|}{$\begin{array}{c}\text { Estimated } \\
\text { Cumulative } \\
\text { Discharges } 2011 \\
\end{array}$} & \multicolumn{2}{|c|}{$\begin{array}{c}\text { Projected } \\
\text { Cumulative } \\
\text { Discharges 2021 } \\
\end{array}$} & \multicolumn{2}{|c|}{$\begin{array}{c}\text { Projected } \\
\text { Cumulative } \\
\text { Discharges } 2031\end{array}$} \\
\hline & & & MTHM & \# Assm & MTHM & \# Assm & MTHM & \# Assm \\
\hline Ginna & 1971 & 2011 & 468 & 1284 & 582 & 1611 & 693 & 1933 \\
\hline Grand Gulf & 1986 & 2011 & 815 & 4598 & 1026 & 5786 & 1255 & 7074 \\
\hline Haddam Neck & 1970 & 1996 & 447 & 1102 & \multicolumn{4}{|c|}{ Final Discharge in 1996} \\
\hline Harris 1 & 1998 & 2011 & 431 & 952 & 619 & 1363 & 799 & 1755 \\
\hline Hatch 1 & 1977 & 2011 & 721 & 3984 & 907 & 5025 & 1070 & 1106 \\
\hline Hatch 2 & 1980 & 2011 & 700 & 3881 & 876 & 4879 & 1033 & 5762 \\
\hline Hope Creek & 1988 & 2010 & 656 & 3637 & 898 & 4997 & 1115 & 6211 \\
\hline Humboldt Bay & 1971 & 1976 & 29 & 390 & \multicolumn{4}{|c|}{ Final Discharge in 1976} \\
\hline Indian Point 1 & 1972 & 1974 & 31 & 160 & \multicolumn{4}{|c|}{ Final Discharge in 1974} \\
\hline Indian Point 2 & 1976 & 2011 & 648 & 1428 & 864 & 571 & 1115 & 1130 \\
\hline Indian Point 3 & 1978 & 2011 & 585 & 1284 & 784 & 1724 & 983 & 2164 \\
\hline Kewaunee & 1976 & 2011 & 454 & 1171 & 566 & 1451 & 674 & 1720 \\
\hline Lacrosse & 1972 & 1987 & 38 & 333 & \multicolumn{4}{|c|}{ Final Discharge in 1987} \\
\hline LaSalle 1 & 1985 & 2011 & 598 & 3325 & 824 & 4605 & 1024 & 5735 \\
\hline LaSalle 2 & 1987 & 2011 & 639 & 3560 & 885 & 4946 & 1101 & 6167 \\
\hline Limerick 1 & 1987 & 2011 & 607 & 3386 & 827 & 4627 & 1028 & 5757 \\
\hline Limerick 2 & 1981 & 2011 & 645 & 3623 & 856 & 4814 & 1060 & 5964 \\
\hline Main Yankee & 1974 & 1996 & 542 & 1434 & \multicolumn{4}{|c|}{ Final Discharge in 1996} \\
\hline McGuire 1 & 1984 & 2011 & 713 & 1590 & 961 & 2136 & 1245 & 2760 \\
\hline McGuire 2 & 1985 & 2011 & 677 & 1510 & 929 & 2065 & 1148 & 2545 \\
\hline Millstone 1 & 1971 & 1995 & 526 & 2884 & \multicolumn{4}{|c|}{ Final Discharge in 1995} \\
\hline Millstone 2 & 1977 & 2011 & 560 & 1417 & 729 & 1843 & 858 & 2166 \\
\hline Millstone 3 & 1987 & 2011 & 506 & 1104 & 706 & 1544 & 929 & 2034 \\
\hline Monticello & 1973 & 2011 & 557 & 3117 & 689 & 3893 & 861 & 4900 \\
\hline Nine Mile Point 1 & 1971 & 2011 & 593 & 3319 & 718 & 4053 & 881 & 5013 \\
\hline Nine Mile Point 2 & 1990 & 2011 & 537 & 3075 & 766 & 4421 & 968 & 5609 \\
\hline North Anna 1 & 1980 & 2011 & 578 & 1249 & 760 & 1641 & 927 & 1999 \\
\hline North Anna 2 & 1982 & 2011 & 619 & 1336 & 772 & 1666 & 937 & 2021 \\
\hline Oconee 1 & 1974 & 2011 & 725 & 1557 & 887 & 1906 & 1022 & 2196 \\
\hline Oconee 2 & 1976 & 2011 & 699 & 1504 & 839 & 1810 & 980 & 2117 \\
\hline Oconee 3 & 1976 & 2011 & 685 & 1465 & 868 & 1853 & 1026 & 2188 \\
\hline Oyster Creek 1 & 1971 & 2011 & 622 & 3488 & 748 & 4219 & 923 & 5241 \\
\hline Palisades & 1975 & 2011 & 588 & 1440 & 748 & 1812 & 951 & 2283 \\
\hline Palo Verde 1 & 1987 & 2011 & 663 & 1551 & 922 & 2144 & 1189 & 2755 \\
\hline Palo Verde 2 & 1988 & 2011 & 662 & 1549 & 937 & 2181 & 1147 & 2660 \\
\hline Palo Verde 2 & 1989 & 2011 & 629 & 1469 & 928 & 2153 & 1188 & 2750 \\
\hline Peach Bottom 2 & 1976 & 2011 & 851 & 4725 & 1086 & 6041 & 1287 & 7160 \\
\hline Peach Bottom 3 & 1976 & 2011 & 853 & 4730 & 1080 & 6004 & 1273 & 7092 \\
\hline Perry 1 & 1989 & 2011 & 643 & 3561 & 879 & 4882 & 1091 & 6063 \\
\hline Pilgrim 1 & 1973 & 2011 & 553 & 3069 & 685 & 3826 & 797 & 4468 \\
\hline Point Beach 1 & 1972 & 2011 & 437 & 1138 & 515 & 1335 & 630 & 1626 \\
\hline Point Beach 2 & 1974 & 2011 & 396 & 1035 & 494 & 1281 & 577 & 1493 \\
\hline Prairie Island 1 & 1976 & 2011 & 423 & 1155 & 518 & 1424 & 605 & 1673 \\
\hline Prairie Island 2 & 1976 & 2011 & 421 & 1149 & 517 & 1422 & 612 & 1692 \\
\hline
\end{tabular}


Inventory and Description of Commercial Reactor Fuels within the United States

March 31, 2011

\begin{tabular}{|c|c|c|c|c|c|c|c|c|}
\hline \multirow[t]{2}{*}{ Reactor Name } & \multirow{2}{*}{$\begin{array}{l}\text { Year First } \\
\text { discharge }\end{array}$} & \multirow{2}{*}{$\begin{array}{c}\text { Discharge } \\
\text { Date By } \\
\text { Year } \\
\text { 2011* }\end{array}$} & \multicolumn{2}{|c|}{$\begin{array}{c}\text { Estimated } \\
\text { Cumulative } \\
\text { Discharges 2011 } \\
\end{array}$} & \multicolumn{2}{|c|}{$\begin{array}{c}\text { Projected } \\
\text { Cumulative } \\
\text { Discharges 2021 } \\
\end{array}$} & \multicolumn{2}{|c|}{$\begin{array}{c}\text { Projected } \\
\text { Cumulative } \\
\text { Discharges 2031 } \\
\end{array}$} \\
\hline & & & MTHM & \# Assm & MTHM & \# Assm & MTHM & \# Assm \\
\hline Quad Cities 1 & 1975 & 2011 & 778 & 4360 & 960 & 5407 & 1119 & 6319 \\
\hline Quad Cities 2 & 1974 & 2011 & 704 & 3925 & 898 & 5050 & 1081 & 6113 \\
\hline Rancho Seco 1 & 1977 & 2011 & 228 & 493 & 228 & 493 & 228 & 493 \\
\hline Robinson 2 & 1973 & 2011 & 656 & 1509 & 791 & 1820 & 971 & 2235 \\
\hline RVR Bend 1 & 1987 & 2010 & 569 & 3204 & 200 & 1138 & 366 & 2086 \\
\hline Salem 1 & 1979 & 2011 & 658 & 1431 & 845 & 1842 & 1040 & 2272 \\
\hline Salem 2 & 1983 & 2011 & 572 & 1244 & 778 & 1694 & 939 & 2048 \\
\hline San Onofre & 1970 & 1992 & 245 & 665 & \multicolumn{4}{|c|}{ Final Discharge in 1992} \\
\hline San Onofre 2 & 1984 & 2011 & 666 & 1581 & 899 & 2117 & 1115 & 2613 \\
\hline San Onofre 3 & 1985 & 2011 & 664 & 1578 & 889 & 2096 & 1069 & 2508 \\
\hline Seabrook 1 & 1981 & 2011 & 513 & 1121 & 748 & 1638 & 938 & 2057 \\
\hline Sequoyah 1 & 1982 & 2011 & 583 & 1273 & 799 & 1749 & 997 & 2185 \\
\hline Sequoyah 2 & 1983 & 2011 & 626 & 1365 & 863 & 1888 & 1051 & 2302 \\
\hline South Texas 1 & 1989 & 2011 & 578 & 1076 & 798 & 1491 & 973 & 1820 \\
\hline South Texas 2 & 1990 & 2011 & 563 & 1050 & 769 & 1437 & 993 & 1860 \\
\hline Saint Lucie 1 & 1978 & 2011 & 703 & 1817 & 861 & 2212 & 1024 & 2622 \\
\hline Saint Lucie 2 & 1984 & 2011 & 517 & 1336 & 695 & 1784 & 854 & 2182 \\
\hline Summer 1 & 1984 & 2011 & 518 & 1206 & 697 & 1634 & 847 & 1995 \\
\hline Surry 1 & 1974 & 2011 & 630 & 1373 & 797 & 1736 & 931 & 2026 \\
\hline Surry 2 & 1975 & 2011 & 625 & 1362 & 809 & 1760 & 958 & 2084 \\
\hline Susquehanna 1 & 1985 & 2011 & 719 & 4070 & 972 & 5497 & 1196 & 6755 \\
\hline Susquehanna 2 & 1985 & 2011 & 707 & 3999 & 954 & 5393 & 1172 & 6621 \\
\hline Trojan & 1978 & 1992 & 359 & 780 & \multicolumn{4}{|c|}{ Final Discharge in 1992} \\
\hline Turkey Point 3 & 1974 & 2011 & 586 & 1284 & 751 & 1648 & 886 & 1948 \\
\hline Turkey Point 4 & 1976 & 2011 & 575 & 1261 & 733 & 1608 & 848 & 1863 \\
\hline Vogtle 1 & 1988 & 2011 & 612 & 1408 & 834 & 1933 & 1012 & 2353 \\
\hline Voglte 2 & 1990 & 2011 & 552 & 1280 & 762 & 1775 & 980 & 2291 \\
\hline VT Yankee 1 & 1973 & 2011 & 637 & 3503 & 786 & 4336 & 934 & 5161 \\
\hline Washington Nuclear & 1986 & 2011 & 641 & 3644 & 863 & 4904 & 1059 & 6013 \\
\hline Waterford 3 & 1986 & 2011 & 634 & 1518 & 901 & 2143 & 1108 & 2628 \\
\hline Watts Bar 1 & 1997 & 2011 & 359 & 780 & 581 & 1263 & 761 & 1655 \\
\hline Wolf Creek 1 & 1986 & 2011 & 653 & 1419 & 893 & 1945 & 1077 & 2348 \\
\hline Yankee Rowe & 1972 & 1991 & 127 & 533 & \multicolumn{4}{|c|}{ Final Discharge in 1991} \\
\hline Zion 1 & 1976 & 1991 & 524 & 1143 & \multicolumn{4}{|c|}{ Final Discharge in 1991} \\
\hline Zion 2 & 1977 & 1996 & 495 & 1083 & \multicolumn{4}{|c|}{ Final Discharge in 1996} \\
\hline Total & & & 66,876 & 232,656 & 86,240 & 295,386 & 105,323 & 355,849 \\
\hline
\end{tabular}


Table 16 Commercial Inventory of Uranium Oxide Fuel being Stored Dry at Argonne National Laboratory - East

\begin{tabular}{|c|c|c|c|c|c|c|c|c|c|c|}
\hline $\begin{array}{l}\text { Fuel Unit Name/ } \\
\text { DOE Facility }\end{array}$ & Fuel Unit Type & $\begin{array}{c}\text { Number } \\
\text { of Fuel } \\
\text { Units }\end{array}$ & $\begin{array}{c}\text { Fuel } \\
\text { Configuration } \\
\end{array}$ & Cladding & $\begin{array}{c}\text { Total } \\
\text { MTHM }\end{array}$ & $\begin{array}{c}\text { Avg } \\
\text { Burnup }\end{array}$ & $\begin{array}{c}\text { Max } \\
\text { Burnup }\end{array}$ & $\begin{array}{c}\text { Date } \\
\text { Removed } \\
\text { from } \\
\text { Reactor } \\
\end{array}$ & $\begin{array}{c}\text { Storage } \\
\text { Date }\end{array}$ & $\begin{array}{l}\text { Storage } \\
\text { Container(s) }\end{array}$ \\
\hline $\begin{array}{l}\text { COMMERCIAL } \\
\text { BWR \& PWR } \\
\text { SNF }\end{array}$ & $\begin{array}{l}\text { SCRAP RODS IN } \\
\text { CANISTER }\end{array}$ & 19 & $\begin{array}{l}\text { CANISTER OF } \\
\text { SCRAP }\end{array}$ & ZIRC & 0.038 & 60,000 & & & & $\begin{array}{l}\text { ANL-E-AGHCF- } \\
\text { DOE TEST }\end{array}$ \\
\hline $\begin{array}{l}\text { DRESII, HBR, } \\
\text { BR-3, BRP, TMI }\end{array}$ & SCRAP IN CANISTER & 1 & $\begin{array}{l}\text { CANISTER OF } \\
\text { SCRAP }\end{array}$ & ZIRC & 0.02 & & 40,000 & $9 / 1 / 79$ & & ANL-E-AGHCF \\
\hline $\begin{array}{l}\text { SURRY (T11 } \\
\text { SCRAP RODS) }\end{array}$ & $\begin{array}{l}\text { SCRAP RODS IN } \\
\text { CANISTER }\end{array}$ & 15 & ROD SECTIONS & ZIRC & 0.006 & 35,722 & 35,722 & $11 / 6 / 81$ & 02/22/01 & $\begin{array}{l}\text { LIMERICK ROD } \\
\text { SECTION } \\
\text { SHIPPING TUBE }\end{array}$ \\
\hline
\end{tabular}

Table 17 Commercial Inventory of Uranium Oxide Fuel being Stored Dry at Hanford Reservation

\begin{tabular}{|c|c|c|c|c|c|c|c|c|c|c|}
\hline $\begin{array}{l}\text { Fuel Unit Name/ } \\
\text { DOE Facility }\end{array}$ & Fuel Unit Type & $\begin{array}{l}\text { Number } \\
\text { of Fuel } \\
\text { Units }\end{array}$ & $\begin{array}{c}\text { Fuel } \\
\text { Configuration }\end{array}$ & Cladding & $\begin{array}{c}\text { Total } \\
\text { MTHM }\end{array}$ & $\begin{array}{c}\text { Avg } \\
\text { Burnup }\end{array}$ & $\begin{array}{c}\text { Max } \\
\text { Burnup }\end{array}$ & $\begin{array}{c}\text { Date } \\
\text { Removed } \\
\text { from } \\
\text { Reactor }\end{array}$ & $\begin{array}{c}\text { Storage } \\
\text { Date }\end{array}$ & Storage Container(s) \\
\hline $\begin{array}{l}\text { HANFORD } \\
\text { COMMERCIAL } \\
\text { TEST SCRAP }\end{array}$ & $\begin{array}{l}\text { CANISTER OF } \\
\text { SCRAP }\end{array}$ & 6 & $\begin{array}{l}\text { CANISTER OF } \\
\text { SCRAP }\end{array}$ & ZIRC & 0.064 & & & $1 / 9 / 82$ & & $\begin{array}{l}\text { 1) EBR-II PIPE } \\
\text { CONTAINER } \\
\text { 2) EBR-II CASK }\end{array}$ \\
\hline GE TEST & $\begin{array}{l}\text { CANISTER OF } \\
\text { SCRAP }\end{array}$ & 22 & $\begin{array}{l}\text { CANISTER OF } \\
\text { SCRAP }\end{array}$ & ZIRC-2 & 0.045 & & & $12 / 31 / 74$ & & $\begin{array}{l}\text { GE TEST-200 WEST } \\
\text { BG-CASK }\end{array}$ \\
\hline $\begin{array}{l}\text { MIXED } \\
\text { PLUTONIUM \& } \\
\text { URANIUM } \\
\text { TEST }^{\mathrm{a}}\end{array}$ & $\begin{array}{l}\text { CANISTER OF } \\
\text { SCRAP }\end{array}$ & 32 & $\begin{array}{l}\text { CANISTER OF } \\
\text { SCRAP }\end{array}$ & SST & 0.2 & & & $1 / 9 / 82$ & & $\begin{array}{l}\text { 1) EBR-II PIPE } \\
\text { CONTAINER } \\
\text { 2) EBR-II CASK }\end{array}$ \\
\hline POINT BEACH & ASSEMBLY & 3 & $\begin{array}{l}14 \text { X } 14 \text { ROD } \\
\text { ARRAY }\end{array}$ & ZIRC-4 & 1.162 & 32,300 & 32,300 & $10 / 9 / 81$ & $12 / 31 / 02$ & $\begin{array}{l}\text { 1) LWR CANISTER } \\
\text { 2) NAC-1 CASK }\end{array}$ \\
\hline
\end{tabular}

\footnotetext{
${ }^{\text {a }}$ Pu alloy
} 
Inventory and Description of Commercial Reactor Fuels within the United States

March 31, 2011

\begin{tabular}{|c|c|c|c|c|c|c|c|c|c|c|}
\hline $\begin{array}{l}\text { Fuel Unit Name/ } \\
\text { DOE Facility }\end{array}$ & Fuel Unit Type & $\begin{array}{c}\text { Number } \\
\text { of Fuel } \\
\text { Units }\end{array}$ & $\begin{array}{c}\text { Fuel } \\
\text { Configuration }\end{array}$ & Cladding & $\begin{array}{c}\text { Total } \\
\text { MTHM }\end{array}$ & $\begin{array}{c}\text { Avg } \\
\text { Burnup }\end{array}$ & $\begin{array}{c}\text { Max } \\
\text { Burnup }\end{array}$ & $\begin{array}{c}\text { Date } \\
\text { Removed } \\
\text { from } \\
\text { Reactor }\end{array}$ & $\begin{array}{c}\text { Storage } \\
\text { Date }\end{array}$ & Storage Container(s) \\
\hline $\begin{array}{l}\text { COOPER } \\
\text { NUCLEAR }\end{array}$ & RODS & 95 & ROD & ZIRC-2 & 0.357 & 27,842 & 28,000 & $5 / 21 / 82$ & $12 / 31 / 02$ & $\begin{array}{l}\text { 1) CONSOLIDATED } \\
\text { ROD CONTAINER } \\
\text { 2) LWR CANISTER } \\
\text { 3) NAC-1 CASK }\end{array}$ \\
\hline $\begin{array}{l}\text { HANFORD LWR } \\
\text { SCRAP }\end{array}$ & $\begin{array}{l}\text { CANISTER OF } \\
\text { SCRAP }\end{array}$ & 3 & $\begin{array}{l}\text { CANISTER OF } \\
\text { SCRAP }\end{array}$ & ZIRC-2 & 0.064 & 35,768 & 42,700 & 9/30/82 & & $\begin{array}{l}\text { 1) HANFORD } \\
\text { ENGINEERED } \\
\text { CONTAINER } \\
\text { 2) GNS-12 CASK }\end{array}$ \\
\hline $\begin{array}{l}\text { CALVERT } \\
\text { CLIFFS } 1 \\
\text { (PARTIAL } \\
\text { ASSEMBLIES) }\end{array}$ & ASSEMBLY & 2 & $\begin{array}{l}14 \text { X } 14 \text { ROD } \\
\text { ARRAY }\end{array}$ & ZIRC-4 & 0.649 & 35,768 & 42,700 & $4 / 17 / 82$ & $12 / 31 / 02$ & $\begin{array}{l}\text { 1) LWR CANISTER } \\
\text { 2) NAC-1 CASK }\end{array}$ \\
\hline $\begin{array}{l}\text { SEGMENT ROD } \\
\text { PROGRAM } \\
\text { (RODS) }\end{array}$ & $\begin{array}{l}\text { ROD } \\
\text { SEGMENTS }\end{array}$ & 6 & ROD SEGMENTS & ZIRC & 0.004 & 23,476 & 23,700 & $9 / 30 / 82$ & $12 / 31 / 02$ & $\begin{array}{l}\text { 1) CONSOLIDATED } \\
\text { ROD CONTAINER } \\
\text { 2) LWR CANISTER } \\
\text { 3) NAC-1 CASK }\end{array}$ \\
\hline SP-100 FUEL & $\begin{array}{l}\text { CANISTER OF } \\
\text { SCRAP }\end{array}$ & 2 & $\begin{array}{l}\text { CANISTER OF } \\
\text { SCRAP }\end{array}$ & N/A & 0.003 & & & $1 / 1 / 92$ & & $\begin{array}{l}\text { 1) EBR-II PIPE } \\
\text { CONTAINER } \\
\text { 2) EBR-II CASK }\end{array}$ \\
\hline $\begin{array}{l}\text { CALVERT } \\
\text { CLIFFS (RODS) }\end{array}$ & RODS & 17 & ROD & ZIRC-4 & 0.034 & 38,106 & 42,700 & 4/17/82 & $12 / 31 / 02$ & $\begin{array}{l}\text { 1) CONSOLIDATED } \\
\text { ROD CONTAINER } \\
\text { 2) LWR CANISTER } \\
\text { 3) NAC-1 CASK }\end{array}$ \\
\hline
\end{tabular}

Note- Fuel composition - all the fuel is U oxide unless indicated 
Table 18 Commercial Inventory of Uranium Oxide Fuel being Stored Dry at Idaho National Laboratory

\begin{tabular}{|c|c|c|c|c|c|c|c|c|c|c|}
\hline $\begin{array}{l}\text { Fuel Unit Name/ } \\
\text { DOE Facility }\end{array}$ & $\begin{array}{c}\text { Fuel Unit } \\
\text { Type } \\
\end{array}$ & $\begin{array}{c}\text { Number } \\
\text { of Fuel } \\
\text { Units }\end{array}$ & Fuel Configuration & Cladding & $\begin{array}{c}\text { Total } \\
\text { MTHM }\end{array}$ & $\begin{array}{c}\text { Avg } \\
\text { Burnup }\end{array}$ & $\begin{array}{c}\text { Max } \\
\text { Burnup }\end{array}$ & $\begin{array}{c}\text { Date } \\
\text { Removed } \\
\text { from } \\
\text { Reactor }\end{array}$ & $\begin{array}{c}\text { Storage } \\
\text { Date }\end{array}$ & Storage Container(s) \\
\hline $\begin{array}{l}\text { DRESDEN I } \\
(\text { E00161) }\end{array}$ & ASSEMBLY & 1 & 6 X 6 ROD ARRAY & ZIRC-2 & 0.1 & 21,808 & 21,808 & $2 / 1 / 73$ & $07 / 24 / 78$ & $\begin{array}{l}\text { 1) DRESDEN OVERPACK } \\
\text { 2) REA } 2023 \text { DRY STORAGE } \\
\text { CASK }\end{array}$ \\
\hline $\begin{array}{l}\text { BRPb - F/PU and } \\
\text { E-G/PU }\end{array}$ & ASSEMBLY & 4 & $9 \times 9$ ROD ARRAY & ZIRC-2 & 0.54 & 14,518 & 16,630 & $6 / 2 / 74$ & $11 / 01 / 74$ & TN-BRP CASK \\
\hline BRP E-G \& E-G/F & ASSEMBLY & 35 & 9 X 9 ROD ARRAY & ZIRC-2 & 4.69 & 13,349 & 18,362 & $3 / 23 / 74$ & $11 / 01 / 74$ & TN-BRP CASK \\
\hline $\begin{array}{l}\text { H. B. ROBINSON } \\
\text { RODS }\end{array}$ & RODS & 12 & ROD & ZIRC-4 & 0.021 & 28,000 & 31,400 & $6 / 1 / 74$ & $12 / 01 / 85$ & $\begin{array}{l}\text { 1) LOFT/COMMERCIAL } \\
\text { SURRY BASKET } \\
\text { 2) REA } 2023 \text { DRY STORAGE } \\
\text { CASK }\end{array}$ \\
\hline BRP-B & ASSEMBLY & 2 & $11 \mathrm{X} 11$ ROD ARRAY & ZIRC-2 & 0.25 & 20,218 & 20,247 & $3 / 18 / 72$ & $11 / 01 / 74$ & TN-BRP CASK \\
\hline $\begin{array}{l}\text { H. B. ROBINSON } \\
\text { (ASSEMBLY) }\end{array}$ & ASSEMBLY & 1 & ASSEMBLY & ZIRC-4 & 0.239 & 28,000 & 31,460 & $6 / 1 / 74$ & $12 / 01 / 85$ & $\begin{array}{l}\text { 1) H B ROBINSON } \\
\text { OVERPACK } \\
\text { 2) REA } 2023 \text { DRY STORAGE } \\
\text { CASK } \\
\end{array}$ \\
\hline BRP-C & ASSEMBLY & 4 & 11 X 11 ROD ARRAY & ZIRC-2 & 0.46 & 24,094 & 24,997 & $3 / 18 / 72$ & $03 / 21 / 68$ & TN-BRP CASK \\
\hline BRP-D1 & ASSEMBLY & 4 & 7 X 7 ROD ARRAY & ZIRC-2 & 0.508 & 1,643 & 1,690 & $6 / 21 / 68$ & $09 / 01 / 73$ & TN-BRP CASK \\
\hline $\begin{array}{l}\text { CONNECTICUT } \\
\text { YANKEE }\end{array}$ & ASSEMBLY & 1 & 15 X 15 ROD ARRAY & $\begin{array}{c}\text { SST } \\
(304 \mathrm{~L})\end{array}$ & 0.382 & 32,151 & 32,151 & $5 / 18 / 75$ & $11 / 01 / 87$ & $\begin{array}{l}\text { 1) CONN. YANKEE } \\
\text { OVERPACK } \\
\text { 2)REA } 2023 \text { DRY STORAGE } \\
\text { CASK }\end{array}$ \\
\hline BRP-D2 & ASSEMBLY & 2 & 8 X 8 ROD ARRAY & ZIRC-2 & 0.217 & 4,546 & 7,027 & $6 / 21 / 68$ & $11 / 01 / 74$ & TN-BRP CASK \\
\hline BRP-E & ASSEMBLY & 18 & 9 X 9 ROD ARRAY & ZIRC-2 & 2.421 & 11,934 & 13,792 & 3/18/72 & $11 / 01 / 74$ & TN-BRP CASK \\
\hline DRCT & RODS & 6936 & ROD & ZIRC-4 & 15.006 & 29,330 & 35,440 & $11 / 6 / 81$ & $12 / 01 / 85$ & $\begin{array}{l}\text { 1) DRCT-TAN-791- } \\
\text { CANISTER (17) } \\
\text { 2) TN 24P CASK }\end{array}$ \\
\hline DRCT & RODS & 2856 & ROD & ZIRC-4 & 6.145 & 29,330 & 35,440 & $11 / 6 / 81$ & $12 / 01 / 85$ & $\begin{array}{l}\text { 1) DRCT-TAN-791- } \\
\text { CANISTER (7) } \\
\text { 2) TN 24P CASK }\end{array}$ \\
\hline BRP-EP ${ }^{b}$ & ASSEMBLY & 3 & 9 X 9 ROD ARRAY & ZIRC-2 & 0.352 & 17,859 & 19,275 & $3 / 23 / 74$ & $11 / 01 / 74$ & TN-BRP CASK \\
\hline
\end{tabular}

\footnotetext{
${ }^{\mathrm{b}} \mathrm{Pu} / \mathrm{U}$ oxide
} 


\begin{tabular}{|c|c|c|c|c|c|c|c|c|c|c|}
\hline $\begin{array}{l}\text { Fuel Unit Name/ } \\
\text { DOE Facility }\end{array}$ & $\begin{array}{c}\text { Fuel Unit } \\
\text { Type }\end{array}$ & $\begin{array}{l}\text { Number } \\
\text { of Fuel } \\
\text { Units }\end{array}$ & Fuel Configuration & Cladding & $\begin{array}{c}\text { Total } \\
\text { MTHM }\end{array}$ & $\begin{array}{c}\text { Avg } \\
\text { Burnup }\end{array}$ & $\begin{array}{c}\text { Max } \\
\text { Burnup }\end{array}$ & $\begin{array}{c}\text { Date } \\
\text { Removed } \\
\text { from } \\
\text { Reactor }\end{array}$ & $\begin{array}{l}\text { Storage } \\
\text { Date }\end{array}$ & Storage Container(s) \\
\hline $\begin{array}{l}\text { LOFT FUEL } \\
\text { RODS }\end{array}$ & RODS & 2 & ROD & ZIRC-4 & 0.002 & 1,420 & 1,420 & $12 / 19 / 84$ & $01 / 01 / 75$ & $\begin{array}{l}\text { 1) LOFT/COMMERCIAL } \\
\text { SURRY BASKET } \\
\text { 2) REA } 2023 \text { DRY STORAGE } \\
\text { CASK }\end{array}$ \\
\hline $\begin{array}{l}\text { DRESDEN I } \\
\text { (UN0064) }\end{array}$ & ASSEMBLY & 1 & 6 X 6 ROD ARRAY & ZIRC-2 & 0.053 & 26,201 & 26,201 & & $07 / 24 / 78$ & $\begin{array}{l}\text { 1) DRESDEN OVERPACK } \\
\text { 2) REA } 2023 \text { DRY STORAGE } \\
\text { CASK }\end{array}$ \\
\hline TURKEY POINT & ASSEMBLY & 5 & 15 X 15 ROD ARRAY & ZIRC-4 & 2.222 & 27,587 & 27,863 & $11 / 19 / 77$ & $12 / 01 / 85$ & MC-10 DRY STORAGE CASK \\
\hline $\begin{array}{l}\text { SURRY (T11 } \\
\text { RODS) }\end{array}$ & RODS & 9 & ROD & ZIRC & 0.019 & 35,722 & 35,722 & $11 / 6 / 81$ & $10 / 17 / 04$ & $\begin{array}{l}\text { 1) LOFT/COMMERCIAL } \\
\text { SURRY BASKET } \\
\text { 2) REA } 2023 \text { DRY STORAGE } \\
\text { CASK }\end{array}$ \\
\hline SURRY & ASSEMBLY & 12 & 15 X 15 ROD ARRAY & ZIRC & 5.314 & 29,776 & 31,551 & $11 / 6 / 81$ & $10 / 19 / 04$ & MC-10 DRY STORAGE CASK \\
\hline $\begin{array}{l}\text { TMI-2 CORE } \\
\text { DEBRIS (D-153 } \\
\& \text { 388) }\end{array}$ & $\begin{array}{l}\text { CANISTER } \\
\text { OF SCRAP }\end{array}$ & 2 & DEBRIS & ZIRC-4 & 0.019 & 3,175 & 5,965 & $3 / 28 / 79$ & 07/01/85 & $\begin{array}{l}\text { 1) TMI CANISTER D-153 \& } \\
\text { D388 } \\
\text { 2) NUPAC 125B-2 DRY } \\
\text { STORAGE CASK }\end{array}$ \\
\hline $\begin{array}{l}\text { PEACH } \\
\text { BOTTOM RODS }\end{array}$ & RODS & 21 & ROD & ZIRC-2 & 0.071 & 10,250 & 11,900 & $3 / 1 / 76$ & $04 / 01 / 77$ & $\begin{array}{l}\text { 1) LOFT/COMMERCIAL } \\
\text { SURRY BASKET } \\
\text { 2) REA } 2023 \text { DRY STORAGE } \\
\text { CASK }\end{array}$ \\
\hline $\begin{array}{l}\text { PEACH } \\
\text { BOTTOM } \\
(\text { ASSEMBLY) }\end{array}$ & ASSEMBLY & 2 & 7 X 7 ROD ARRAY & ZIRC-2 & 0.285 & 10,250 & 11,900 & $3 / 1 / 76$ & $04 / 01 / 77$ & $\begin{array}{l}\text { 1) PEACH BOTTOM } \\
\text { OVERPACK } \\
\text { 2) REA } 2023 \text { DRY STORAGE } \\
\text { CASK }\end{array}$ \\
\hline $\begin{array}{l}\text { SURRY (T11 } \\
\text { ASSEMBLY) }\end{array}$ & ASSEMBLY & 1 & 15 X 15 ROD ARRAY & ZIRC & 0.414 & 35,722 & 35,722 & $11 / 6 / 81$ & $10 / 15 / 04$ & GNS CASTOR V/21 CASK \\
\hline
\end{tabular}


Inventory and Description of Commercial Reactor Fuels within the United States

\begin{tabular}{|c|c|c|c|c|c|c|c|c|c|c|}
\hline $\begin{array}{l}\text { Fuel Unit Name/ } \\
\text { DOE Facility }\end{array}$ & $\begin{array}{l}\text { Fuel Unit } \\
\text { Type }\end{array}$ & $\begin{array}{l}\text { Number } \\
\text { of Fuel } \\
\text { Units }\end{array}$ & Fuel Configuration & Cladding & $\begin{array}{l}\text { Total } \\
\text { MTHM }\end{array}$ & $\begin{array}{c}\text { Avg } \\
\text { Burnup }\end{array}$ & $\begin{array}{c}\text { Max } \\
\text { Burnup }\end{array}$ & $\begin{array}{c}\text { Date } \\
\text { Removed } \\
\text { from } \\
\text { Reactor }\end{array}$ & $\begin{array}{l}\text { Storage } \\
\text { Date }\end{array}$ & Storage Container(s) \\
\hline $\begin{array}{l}\text { ROBERT E. } \\
\text { GINNA }\end{array}$ & ASSEMBLY & 40 & 14 X 14 ROD ARRAY & ZIRC-4 & 15.127 & 10,117 & 14,293 & $4 / 15 / 72$ & $06 / 01 / 73$ & TN-REG \\
\hline $\begin{array}{l}\text { TURKEY POINT } \\
3 \text { (TP3) B-17 }\end{array}$ & ASSEMBLY & 1 & 15 X 15 ROD ARRAY & ZIRC-4 & 0.412 & 27,577 & 27,577 & $10 / 31 / 75$ & $10 / 28 / 87$ & MC-10 DRY STORAGE CASK \\
\hline $\begin{array}{l}\text { LOOSE FUEL } \\
\text { ROD STORAGE } \\
\text { BASKET } \\
\text { (LFRSB) }\end{array}$ & $\begin{array}{l}\text { CANISTER } \\
\text { OF SCRAP }\end{array}$ & 1 & $\begin{array}{l}\text { CANISTER OF } \\
\text { SCRAP }\end{array}$ & ZIRC & 0.312 & & & $12 / 23 / 87$ & $10 / 01 / 87$ & $\begin{array}{l}\text { 1) LFSRB OVERPACK } \\
\text { 2) REA } 2023 \text { DRY STORAGE } \\
\text { CASK }\end{array}$ \\
\hline $\begin{array}{l}\text { LOFT SQUARE } \\
\text { FUEL MODULE }\end{array}$ & ASSEMBLY & 4 & 15 X 15 ROD ARRAY & ZIRC-4 & 0.813 & 6,200 & 6,200 & 7/9/85 & $01 / 01 / 75$ & $\begin{array}{l}\text { TN-24P DRY STORAGE } \\
\text { CASK }\end{array}$ \\
\hline $\begin{array}{l}\text { LOFT CORNER } \\
\text { FUEL MODULE }\end{array}$ & ASSEMBLY & 4 & 12 X 12 ROD ARRAY & ZIRC-4 & 0.279 & 6,200 & 6,200 & 7/9/85 & $01 / 01 / 75$ & $\begin{array}{l}\text { TN-24P DRY STORAGE } \\
\text { CASK }\end{array}$ \\
\hline $\begin{array}{l}\text { LOFT CENTER } \\
\text { FUEL MODULE } \\
(\mathrm{A} 1, \mathrm{~A} 2, \mathrm{~A} 3, \mathrm{~F} 1) \\
\end{array}$ & ASSEMBLY & 4 & 15 X 15 ROD ARRAY & ZIRC-4 & 0.809 & 1,413 & 2,400 & $3 / 5 / 84$ & $01 / 01 / 75$ & $\begin{array}{l}\text { TN-24P DRY STORAGE } \\
\text { CASK }\end{array}$ \\
\hline $\begin{array}{l}\text { TMI-2 CORE } \\
\text { DEBRIS }\end{array}$ & $\begin{array}{l}\text { CANISTER } \\
\text { OF SCRAP }\end{array}$ & 341 & DEBRIS & ZIRC-4 & 81.588 & 3,175 & 5,965 & $3 / 28 / 79$ & 06/30/01 & $\begin{array}{l}\text { 1) TMI CANISTER (IN DSC'S) } \\
\text { 2) DRY SHIELDED CASK }\end{array}$ \\
\hline
\end{tabular}

Note- Fuel composition - all the fuel is U oxide unless indicated 
Table 19 Commercial Inventory of Uranium Oxide Fuel being Stored Wet at the Savannah River Site

\begin{tabular}{|c|c|c|c|c|c|c|c|c|c|c|}
\hline $\begin{array}{l}\text { Fuel Unit Name/ DOE } \\
\text { Facility }\end{array}$ & Fuel Unit Type & $\begin{array}{c}\text { Number } \\
\text { of Fuel } \\
\text { Units }\end{array}$ & $\begin{array}{c}\text { Fuel } \\
\text { Configuration }\end{array}$ & Cladding & $\begin{array}{c}\text { Total } \\
\text { MTHM }\end{array}$ & $\begin{array}{c}\text { Avg } \\
\text { Burnup }\end{array}$ & $\begin{array}{c}\text { Max } \\
\text { Burnup }\end{array}$ & $\begin{array}{c}\text { Date } \\
\text { Removed } \\
\text { from } \\
\text { Reactor } \\
\end{array}$ & $\begin{array}{c}\text { Storage } \\
\text { Date }\end{array}$ & $\begin{array}{l}\text { Storage } \\
\text { Container(s) }\end{array}$ \\
\hline SAXTON & RODS & 25 & ELEMENT & SST & 0.096 & & 1.000 & $4 / 30 / 72$ & $04 / 30 / 74$ & \\
\hline SAXTON & RODS & 20 & ELEMENT & SST & 0.01 & & 1.600 & 4/30/72 & $04 / 30 / 74$ & \\
\hline SAXTON & RODS & 43 & ELEMENT & ZIRC & 0.24 & & 1.000 & $4 / 30 / 72$ & $04 / 30 / 74$ & \\
\hline HWCTR OT & ELEMENT & 8 & TUBE & ZIRC & 0.14 & & 1.500 & $2 / 14 / 64$ & $01 / 01 / 66$ & \\
\hline N.S. SAVANNAH & ELEMENT & 12 & UNKNOWN & ZIRC & 0.021 & & 1.500 & $11 / 5 / 65$ & $01 / 01 / 66$ & \\
\hline DRESDEN $^{\mathrm{C}} \mathrm{I}$ & RODS & 1.273 & ROD & SST & 2.543 & 10.951 & 11.700 & $3 / 29 / 65$ & 01/01/66 & $\begin{array}{l}\text { DRESDEN TS } \\
\text { CAN }\end{array}$ \\
\hline LWR SAMPLES $^{\mathrm{d}}(\mathrm{MOX})$ & RODS & 5 & ROD & ZIRC OR SST & 0.013 & & & $8 / 20 / 81$ & $01 / 01 / 66$ & \\
\hline H. B. ROBINSON & $\begin{array}{l}\text { SCRAP RODS } \\
\text { IN CANISTER }\end{array}$ & 1 & $\begin{array}{l}\text { CANISTER OF } \\
\text { SCRAP }\end{array}$ & ZIRC-4 & 0.001 & & 30.000 & $8 / 4 / 83$ & & $\mathrm{P}-214$ \\
\hline SHIPPINGPORT & RODS & 127 & ROD & ZIRC-2 & 0.017 & & 18.000 & $1 / 1 / 64$ & 1981 & \\
\hline
\end{tabular}

Note- Fuel composition - all the fuel is U oxide unless indicated

Table 20 Commercial Fuel Inventory of Uranium Oxide Fuel being Stored Dry at B\&W Lynchburg Technology Center

\begin{tabular}{|c|c|c|c|c|c|c|c|c|c|c|}
\hline $\begin{array}{l}\text { Fuel Unit } \\
\text { Name/ DOE } \\
\text { Facility }\end{array}$ & Fuel Unit Type & $\begin{array}{c}\text { Number } \\
\text { of Fuel } \\
\text { Units }\end{array}$ & Fuel Configuration & Cladding & $\begin{array}{c}\text { Total } \\
\text { MTHM }\end{array}$ & $\begin{array}{c}\text { Avg } \\
\text { Burnup }\end{array}$ & $\underset{\text { Murnup }}{\text { Max }}$ & $\begin{array}{c}\text { Date } \\
\text { Removed } \\
\text { from } \\
\text { Reactor }\end{array}$ & $\begin{array}{c}\text { Storage } \\
\text { Date }\end{array}$ & Storage Container(s) \\
\hline ARKANSAS & ELEMENT & 3 & SCRAP & ZIRC-4 & 0.012 & 47,000 & & $9 / 1 / 86$ & $07 / 19 / 87$ & \\
\hline TMI-2 & $\begin{array}{l}\text { CANISTER OF } \\
\text { SCRAP }\end{array}$ & 1 & $\begin{array}{l}\text { CANISTER OF } \\
\text { SCRAP }\end{array}$ & ZIRC-4 & 0 & 3,175 & 5,965 & 7/1/85 & & $\begin{array}{l}\text { TMI-B\&W-NESI- } \\
\text { DEBRIS }\end{array}$ \\
\hline OCONEE & ELEMENT & 14 & ROD & ZIRC-4 & 0.032 & 33,835 & 50,000 & 9/1/86 & & \\
\hline
\end{tabular}

\footnotetext{
${ }^{\mathrm{c}} \mathrm{Th} / \mathrm{U}$ oxide

${ }^{\mathrm{d}} \mathrm{Pu} / \mathrm{U}$ oxide
} 
Table 21 Supplemental Information on Commercial Fuel Inventory at B\&W Lynchburg Technology Center

\begin{tabular}{|c|c|c|c|c|c|c|c|c|c|c|}
\hline $\begin{array}{l}\text { Date } \\
\text { Received }\end{array}$ & $\begin{array}{l}\text { Assembly } \\
\text { Number }\end{array}$ & $\begin{array}{l}\text { Power } \\
\text { Station } \\
\end{array}$ & $\begin{array}{l}\text { Unit No./ } \\
\text { Cycle No }\end{array}$ & $\begin{array}{l}\text { MWD/T } \\
\text { Burnup }\end{array}$ & $\begin{array}{c}\text { No of Rods } \\
\text { on Site } \\
\text { (Sectioned) } \\
\end{array}$ & $\begin{array}{c}\text { Uranium } \\
\% \text { Enrichment } \\
\text { or Depleted }\end{array}$ & $\begin{array}{c}\text { Depleted } \\
\text { Uranium } \\
\text { Grams } \\
\end{array}$ & $\begin{array}{c}\text { Enriched } \\
\text { Uranium } \\
\text { Grams } \\
\end{array}$ & $\begin{array}{c}\text { Grams } \\
\text { Isotope } \\
\text { (U-235) } \\
\end{array}$ & Owner \\
\hline $8 / 23 / 1976$ & $1 \mathrm{C} 56$ & Oconee & $1 / 2$ & 18,686 & 0.333 & 0.8 & 0 & 531 & 4 & Private \\
\hline 3/15/1978 & $1 \mathrm{C} 66$ & Oconee & $1 / 3$ & 26,480 & 3 & 0.51 & 6482 & 0 & 34 & Private \\
\hline $1 / 18 / 1978$ & 2B40 & Oconee & $2 / 2$ & 27,500 & 5 & 0.98 & 0 & 10711 & 105 & Private \\
\hline $5 / 31 / 1980$ & 1D54 & Oconee & $1 / 3$ & 31,160 & 2 & 0.96 & 0 & 4275 & 41 & DOE \\
\hline \multirow[t]{2}{*}{$12 / 5 / 1980$} & 1D13 & Oconee & $1 / 4$ & 39,180 & 5 & 0.52 & 10554 & 0 & 55 & DOE \\
\hline & & & & & & 7.8 & 0 & 706 & 55 & Private \\
\hline $3 / 1 / 1966$ & & Indian Point & & 33,000 & & $52.75 \mathrm{Av}$. & 0 & 91 & 48 & Private \\
\hline $10 / 27 / 1983$ & TMI-2 Fuel Debris & & & & & 2.36 & 0 & 16 & * & DOE \\
\hline $2 / 4 / 1984$ & $1 \mathrm{D} 45$ & Oconee & $1 / 8$ & 50,000 & 4 & 0.353 & 8250 & 0 & 29 & DOE \\
\hline 7/13/1985 & NJ037P & Oconee & $1 / 1$ & 15,000 & 4 & $1.3(\mathrm{a})$ & 0 & 7886 & 102 & DOE \\
\hline 9/19/1986 & LJG764 & CECO & $2 / 7$ & 29,523 & 2 & 0.6271 & 5422 & 0 & 34 & Private \\
\hline 9/19/1986 & LJG769 & CECO & $2 / 7$ & 29,524 & 2 & 0.4485 & 5427 & 0 & 24 & Private \\
\hline 3/13/1987 & TMI-2 Fuel Debris & & & & & 2.98 & 0 & 32 & 1 & Private \\
\hline 7/19/1987 & NJ023Q & Arkansas & $1 / 3$ & 47,000 & 6 & 0.3923 & 11752 & 0 & 45 & DOE \\
\hline 12/10/1988 & NJ01jE & Oconee & $2 / 2$ & 31,000 & 3 & 0.6691 & 0 & 6412 & 57 & Private \\
\hline $12 / 10 / 1988$ & NJ01P & Oconee & $2 / 3$ & 36,000 & 1 & 0.7049 & 1999 & 0 & 14 & Private \\
\hline 10/1/1989 & NJ037K & Oconee & $1 / 4$ & 59,300 & 8 & $.3232(a)$ & 14543 & 0 & 36 & Private \\
\hline \multirow[t]{2}{*}{$3 / 25 / 1994$} & NJ044J & McGuire & $1 / 3$ & 42,984 & 3 & 0.497 & 5001 & 0 & 24 & Private \\
\hline & & & & 45,000 & & $31.00(a)$ & 0 & 2126 & 659 & Private \\
\hline $8 / 3 / 2006$ & NJ092T & North Anna & $1 \& 2 / 4$ & 70,000 & Residue & 0.439 Av. & 647 & 0 & 3 & DOE \\
\hline Total & & & & & 50.333 & & 72,140 & 34,945 & 1,405 & \\
\hline
\end{tabular}


Table 22 University Research Reactors Reporting Spent Fuel (CRS)

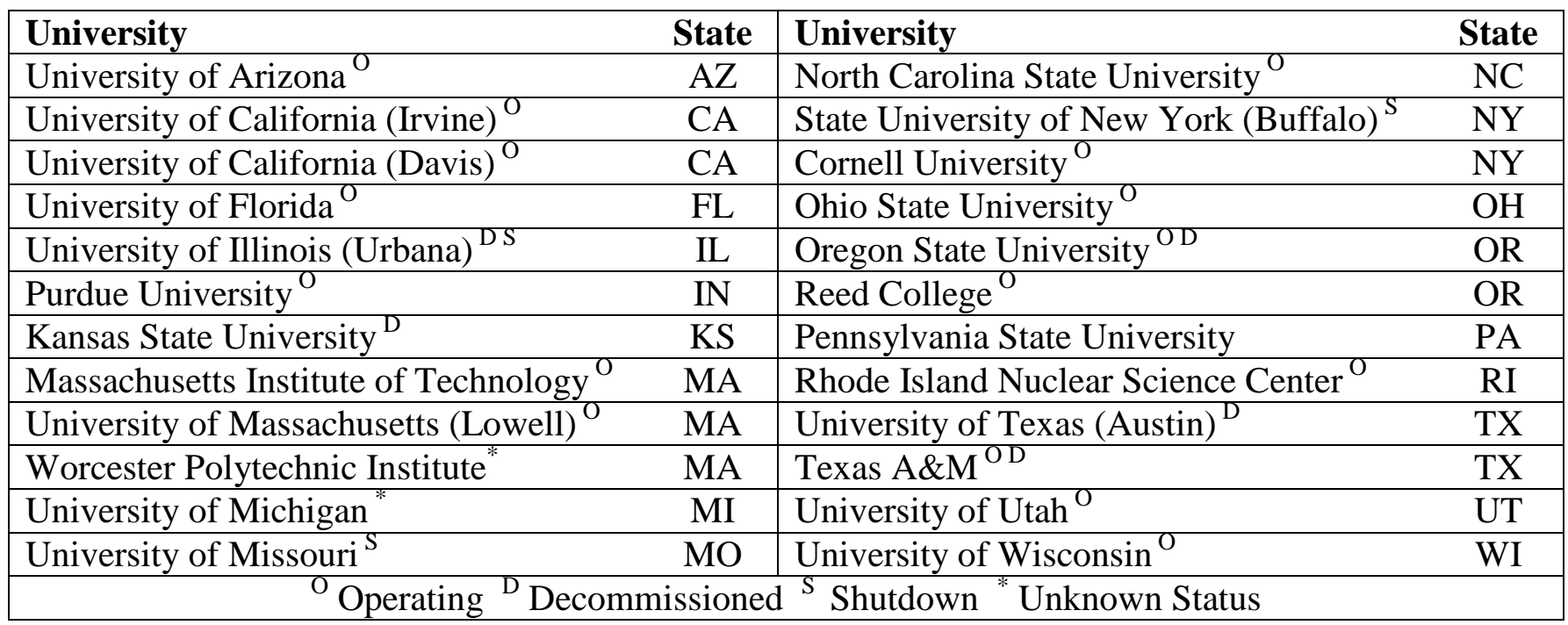

